\title{
19. GEOCHEMICAL CHANGES DURING HYDROTHERMAL ALTERATION OF BASEMENT IN THE STOCKWORK BENEATH THE ACTIVE TAG HYDROTHERMAL MOUND ${ }^{1}$
}

\author{
Susan E. Humphris, ${ }^{2}$ Jeffrey C. Alt, ${ }^{3}$ Damon A.H. Teagle, ${ }^{3}$ and Jose J. Honnorez ${ }^{4}$
}

\begin{abstract}
Major, trace, and rare earth element (REE) analyses of 57 samples of altered and relatively fresh basalts from four different areas on the active Trans-Atlantic Geotraverse (TAG) hydrothermal mound have been completed to determine the geochemistry of alteration of the shallow oceanic crust beneath the mound and to calculate the magnitudes and directions of elemental exchanges between seawater and the oceanic crust during each step of the alteration sequence.

Early high-temperature water-rock reactions resulted in the initial conversion of fresh basalt to chlorite \pm quartz \pm pyrite by reactions between basalt and a hydrothermal fluid-seawater mixture. Fluid-rock reactions resulted in uptake of $\mathrm{Al}, \mathrm{Fe}, \mathrm{Mg}$, $\mathrm{H}_{2} \mathrm{O}^{+}, \mathrm{S}, \mathrm{V}$, and $\mathrm{Co}$. In addition, essentially all of the $\mathrm{Ca}, \mathrm{Na}$, and $\mathrm{Sr}$ were lost from the rock during alteration of plagioclase. The trace metals $\mathrm{Cu}, \mathrm{Ni}$, and $\mathrm{Zn}$ were leached from the rock, with almost all of the $\mathrm{Cu}$ being removed. Changes in Si were variable in direction and in general quite small. This was followed by replacement of the chlorite-rich assemblage by paragonite \pm quartz \pm pyrite during reactions with a hydrothermal fluid enriched in alkalis. This resulted in additional uptake of $\mathrm{Si}, \mathrm{Fe}, \mathrm{S}$, and $\mathrm{Co}$, as well as small amounts of $\mathrm{Na}, \mathrm{K}, \mathrm{Sr}, \mathrm{Ba}$, and $\mathrm{Zn}$. Other components were lost from the rock, including $\mathrm{Mg}, \mathrm{H}_{2} \mathrm{O}^{+}$, and $\mathrm{V}$, and small amounts of Al. Further silicification of the paragonite-rich assemblage resulted in continuing and complete loss of $\mathrm{Mg}$ and $\mathrm{H}_{2} \mathrm{O}^{+}$, and almost complete loss of $\mathrm{V}$. This stage of the alteration sequence is also responsible for the largest increases in the $\mathrm{Si}, \mathrm{Fe}, \mathrm{S}$, and $\mathrm{Co}$ contents of the altered rocks, some of which show gains in $\mathrm{Cu}$ and $\mathrm{Zn}$, presumably in association with the sulfides.

Chloritization within basalts from the edges of the mound attests to reactions between hydrothermal fluids and rocks at high temperatures extending in the subsurface at least to the periphery of the mound. Distinct geochemical and mineralogical differences during alteration on different parts of the mound are indicative of fluids with varying proportions of hydrothermal fluids and seawater.
\end{abstract}

\section{INTRODUCTION}

Quantifying the chemical fluxes associated with hydrothermal circulation at mid-ocean ridges is key to evaluating the role of waterrock reactions in regulating the chemistry of seawater and to determining the composition of the crust that is returned to the mantle by subduction. Previous studies of hydrothermally altered samples dredged or collected by submersible from scarps along the global mid-ocean ridge system (e.g., Hart, 1970; Thompson, 1973; Humphris and Thompson, 1978a, 1978b; Hart and Staudigel, 1982; Thompson, 1983; Gillis et al., 1993), from off-axis drillholes (e.g., Donnelly et al., 1979; Alt and Honnorez, 1984; Alt et al., 1986, 1989), and from ophiolites (e.g., Gillis and Robinson, 1985, 1990; Harper et al., 1988; Alt, 1994; Nehlig et al., 1994) have documented a wide range of water-rock interactions and geochemical changes. These studies have resulted in a conceptual model for the alteration reactions that occur within different portions of the hydrothermal circulation cell (Alt, 1995).

Upflow zones of active hydrothermal systems are manifest on the seafloor as vents discharging high-temperature fluids that, on mixing with seawater, result in the formation of mineral deposits and metalliferous sediments. However, very few subsurface mineralization and shallow stockwork feeder zones have been identified and studied (Alt et al., 1986, 1989; Embley et al., 1988; Fouquet et al., 1993; Ridley et al., 1994). Consequently, our understanding of water-rock interac-

${ }^{1}$ Herzig, P.M., Humphris, S.E., Miller, D.J., and Zierenberg, R.A. (Eds.), 1998. Proc. ODP, Sci. Results, 158: College Station, TX (Ocean Drilling Program).

${ }^{2}$ Department of Geology and Geophysics, Woods Hole Oceanographic Institution, Woods Hole, MA 02543, U.S.A. shumphris@whoi.edu

${ }^{3}$ Department of Geological Sciences, The University of Michigan, 2534 C.C. Little Building, Ann Arbor, MI 48109, U.S.A.

${ }^{4}$ Institut de Géologie, Université Louis Pasteur, 1 rue Blessig, 67084 Strasbourg Cedex, France. tions in upflow zones, particularly in the deeper parts of hydrothermal systems, is based almost entirely on evidence from ophiolites (e.g. Richardson et al., 1987; Schiffman and Smith, 1988; Zierenberg et al., 1988; Bettison-Varga et al., 1992; Nehlig et al., 1994), although studies of hydrothermal breccias recovered from the seafloor (Delaney et al., 1987; Saccocia and Gillis, 1995; Zierenberg et al., 1995) have provided additional constraints on the reactions within the shallow parts of hydrothermal upflow zones.

Leg 158 of the Ocean Drilling Program provided the opportunity to investigate the rock-water reactions and associated elemental exchanges within the shallowest portions of the hydrothermal upflow zone beneath an actively forming mineral deposit on the seafloor. In this paper, we present data on the geochemistry of alteration of the oceanic crust beneath the active Trans-Atlantic Geotraverse (TAG) hydrothermal mound and calculate the directions and magnitudes of elemental exchange between seawater and the oceanic crust for different types of alteration.

\section{THE ACTIVE TAG HYDROTHERMAL MOUND}

The TAG hydrothermal field is located at $26^{\circ} 08^{\prime} \mathrm{N}$ at the midpoint of a 40-km-long ridge segment at the base of the eastern rift valley wall (Fig. 1, inset). It covers an area of at least $5 \times 5 \mathrm{~km}$ and includes active low- and high-temperature zones, as well as inactive deposits (Rona et al., 1993a, 1993b). High-temperature hydrothermal activity is confined to a mound that lies $2.5 \mathrm{~km}$ east of the neovolcanic zone in an area where the intersection of actively developing ridge-parallel (NNE) faults and fissures with a series of preexisting, obliquely oriented (ENE) faults may provide permeable pathways through fault breccias for upflow of hydrothermal fluids (Kleinrock and Humphris, 1996; Kleinrock et al., 1996). Alignment of structural features on the mound and the proximal seafloor indicates that both

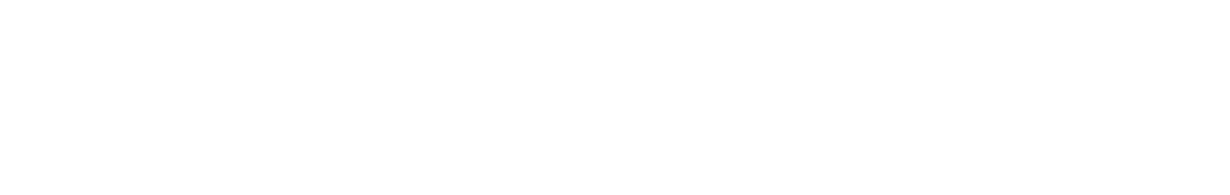




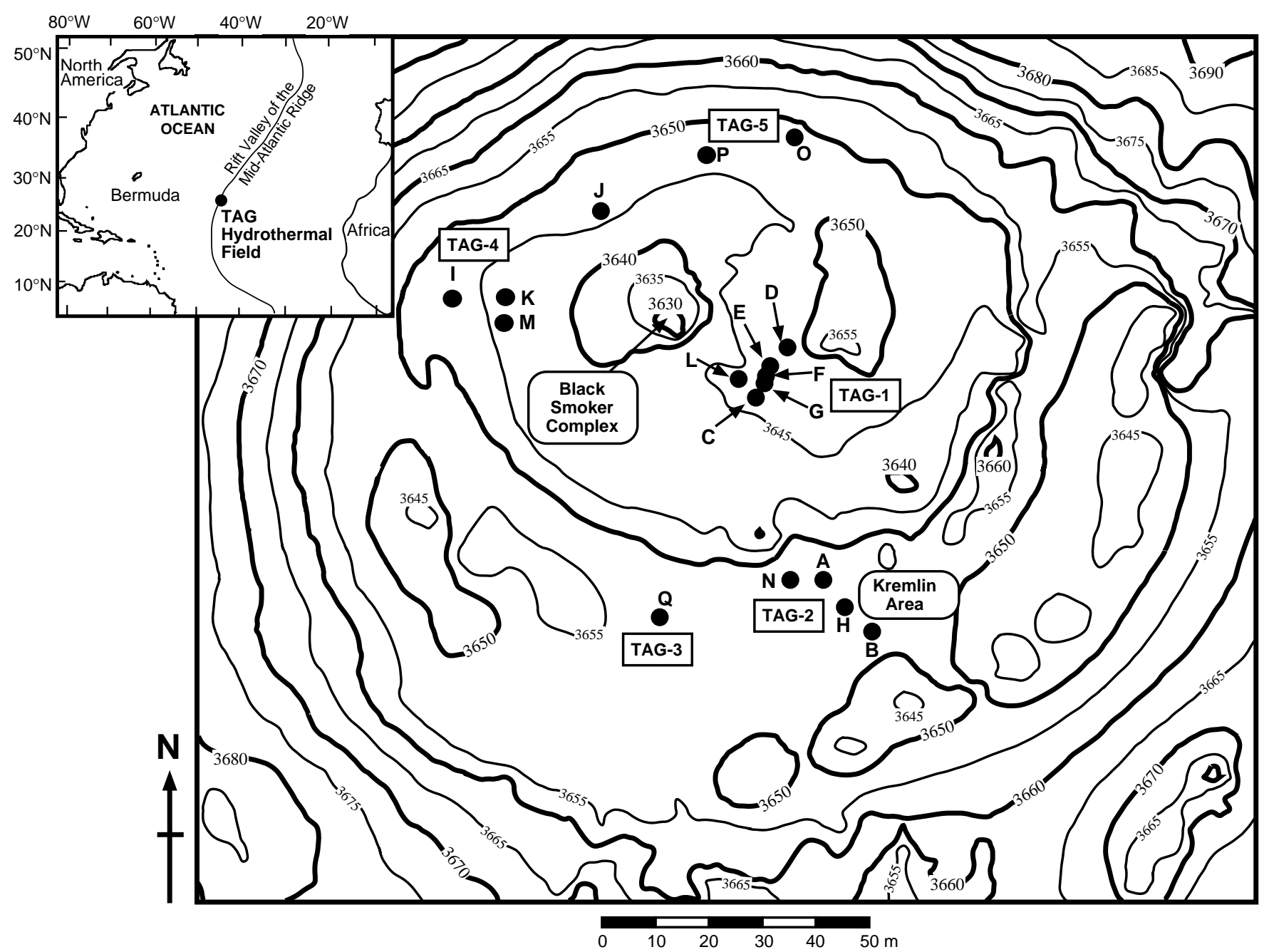

Figure 1. High-resolution bathymetry (5-m contour interval) of the active TAG mound, showing its overall structure and the locations of the holes drilled during Leg 158 (Humphris et al., 1995). Inset = location of the TAG hydrothermal field on the Mid-Atlantic Ridge.

are undergoing extension, and evidence from the morphology of the mound suggests that the hydrogeology of the hydrothermal system is continually being modified by tectonic deformation processes (Humphris and Kleinrock, 1996; Kleinrock and Humphris, 1996). A magnetic low directly beneath the active TAG mound has been interpreted as the alteration pipe of the upflow zone beneath the mound (Tivey et al., 1993).

Based on geochronological studies, the TAG hydrothermal mound is believed to have been active episodically every 4000-5000 yr over at least the last 20,000 yr (Lalou et al., 1990, 1993). Its surface morphology has been described in detail (Thompson et al., 1988; Rona et al., 1993b; Tivey et al., 1995; Humphris and Kleinrock, 1996; Kleinrock et al., 1996). Briefly, the mound is a circular feature, about $200 \mathrm{~m}$ in diameter, the surface of which is composed of massive sulfides and anhydrite. Two discrete platforms (Fig. 1) suggest at least two major phases of active growth (Humphris and Kleinrock, 1996). The top of the lower platform is about $150 \mathrm{~m}$ in diameter and is at a depth of $3650-3655 \mathrm{~m}$. The upper platform is asymmetrically superposed on the north-northwest portion of the lower platform, and is about $90 \mathrm{~m}$ in diameter at a depth of 3642-3650 m (Fig. 1; Kleinrock and Humphris, 1996). Samples of amorphous iron oxyhydroxide and silica have been collected from the west, south, and east rims of the mound, and mixed $\mathrm{Zn}, \mathrm{Fe}$, and $\mathrm{Cu}-\mathrm{Fe}$ sulfides with cavities filled with amorphous silica have been recovered from the northern rim and central portions of the mound (Tivey et al., 1995). Apart from diffuse flow, which discharges over much of the surface of the mound, there are two areas of focused fluid flow. The Black Smoker Complex is located just to the west of the center of the upper platform. It comprises a cluster of chalcopyrite-anhydrite-rich chimneys vigorously discharging high-temperature $\left(363^{\circ} \mathrm{C}\right), \mathrm{Cu}$-rich fluids that are forming at the summit of a 20- to 30-m diameter cone, the surface of which is a platy layer of massive chalcopyrite and marcasite with blocks of corroding massive anhydrite. The white smoker ("Kremlin") area is located on the southeast quadrant of the lower platform (Thompson et al., 1988; Rona et al., 1993b; Tivey et al., 1995). Small (1-2 m) spires composed dominantly of low-Fe sphalerite with minor amounts of chalcopyrite, pyrite and amorphous silica discharge lower temperature $\left(260^{\circ}-300^{\circ} \mathrm{C}\right)$ fluids that have a very low $\mathrm{pH}\left(3\right.$ at $\left.23^{\circ} \mathrm{C}\right)$ and high concentrations of zinc (300-400 $\mu \mathrm{mol}^{-1^{-1}}$ ) (Edmond et al., 1995). The distinct fluid chemistries of the black and white smokers are thought to be related through processes of conductive cooling, mixing with entrained seawater, and precipitation and dissolution of various mineral phases within the mound (Edmond et al., 1995; Tivey et al., 1995).

\section{SITE 957}

Seventeen holes were drilled at Site 957 in five major areas (TAG-1 through TAG-5) of the active TAG hydrothermal mound 
(Fig. 1). Maximum penetration was achieved at Hole 957E (the TAG1 area) where drilling extended through the mound and into the upper part of the upflow zone, reaching a depth of $125.7 \mathrm{mbsf}$. The average recovery for Site 957 was low ( 12\%); however, based on composite sections derived from several holes in each area, the mound has been divided into several distinct lithologic zones composed of breccias of various types (Humphris et al., 1995; Fig. 2). In the following description, we concentrate on the nature and distribution of altered basement samples.

Silicified basaltic clasts that are centimeter sized occur within the mound as shallow as $10 \mathrm{mbsf}$ and are found in the pyrite, pyriteanhydrite, and pyrite-silica breccias. In general, their abundance increases with depth, with the highest abundance being in the pyritesilica breccias, which consist of clasts of both pyrite \pm quartz and silicified basalt in a quartz-rich matrix.

The pyrite-silica breccias represent the top of the stockwork zone at a depth of between 25 and 35 mbsf. This is underlain by a zone of silicified wallrock breccias consisting of light gray fragments of silicified basalt veined and cemented with quartz \pm pyrite. In the TAG-1 and TAG-2 areas, this zone is first encountered at depths of about 40$45 \mathrm{~m}$, whereas in the TAG- 4 area, it occurs at about $30 \mathrm{mbsf}$. On the northern side of the upper platform (the TAG-5 area), fragments of these breccias were recovered from Hole 957P in Cores 8R-11R at depths from 35 to 54 mbsf. In the TAG-1 area at depths below about $101 \mathrm{mbsf}$, the silicified wallrock breccias become less silicified and more paragonitized and grade into chloritized basalt breccias at about 110 mbsf, although both paragonitized basalts (which appear gray in hand specimen) and chloritized basalts (which appear green in hand specimen) occur below 100 mbsf.

Basalts inferred to be basement were encountered beneath the margins of the mound in the TAG-2 and TAG-4 areas. Hole 957B, located near the edge of the lower platform (Fig. 1) in the TAG-2 area, penetrated about $20 \mathrm{~m}$ of sulfides before drilling a $30-\mathrm{cm}$ section of hydrothermally altered pillow breccia, consisting of basalt and glass fragments replaced by chlorite and quartz in a matrix of chlorite + quartz. This is underlain by about $10 \mathrm{~m}$ of weakly altered basalt, in which smectite and iron oxides/oxyhydroxides replace olivine and fill vesicles. Many basaltic fragments exhibit more intensively altered, red-brown alteration halos (up to $5 \mathrm{~mm}$ wide) in which the rock is totally replaced by chlorite and stained by iron oxides/oxyhydroxides. On the western side of the upper platform (the TAG-4 area), 9 $\mathrm{m}$ of moderately altered dark gray basalts with partially chloritized alteration halos were encountered at about 42 mbsf. Smectite and talc partly to totally replace olivine and fill vesicles in the interior portions of the basalts; in the halos, chlorite and mixed layer chloritesmectite partially to totally replace olivine, pyroxene and plagioclase, and fill vesicles.

\section{SAMPLE SELECTION AND METHODS}

Samples of altered basalt were cut from clasts within the pyrite, pyrite-anhydrite, and pyrite-silica breccias from the TAG-1, TAG-2, TAG-4, and TAG-5 areas. In addition, samples were selected from the silicified wallrock breccias in the TAG-1, TAG-2, and TAG-4 areas, and from the more paragonitized basalts and chloritized basalts at the bottom of Hole 957E (the TAG-1 area), taking care to avoid large (several millimeter) veins. These breccias do, however, commonly contain extremely fine vein networks, typically of pyrite and quartz, that were difficult to avoid during sampling. Consequently, the amount and type of veining present were noted for each sample and used to select those samples appropriate for quantification of elemental gains and losses. Samples of the relatively unaltered basalts from the TAG-2 and TAG-4 areas were also selected for analysis to provide a precursor basalt composition to determine the geochemical effects of alteration. In addition, chloritized alteration halos were separated from the fresher interior portions of samples from Hole 957M (the TAG-4 area) to provide altered-fresh pairs from the same rock. Clasts from the pillow breccia from Hole 957B at TAG-2 were also separated and analyzed, including blue-green chloritized glass (Sample 158-957B-4R-1, Piece 4, 39-41 cm) and reddish chloritized basalt (Sample 158-957B-4R-1, Piece 2, 17-24 cm). Petrographic studies and mineralogical analyses of thin sections cut from the same samples are presented in Honnorez et al. (Chap. 18, this volume). Finally, two powders prepared and analyzed on board ship were included in the sample suite to permit assessment of consistency of analyses between shore-based laboratories.

The samples were ground and powdered using a Cr-steel barrel in a shatterbox, and then subsamples were taken for bulk geochemical analyses (this study) and for strontium- and oxygen-isotope studies (Alt and Teagle, Chap. 21, this volume; Teagle et al., Chap. 22, this volume). Total $\mathrm{S}, \mathrm{H}_{2} \mathrm{O}^{+}$, and $\mathrm{CO}_{2}$ contents were determined by gas chromatography using a Fison's EA1108 CHNS Analyzer. Major and selected trace elements were determined using a Thermo JarrellAsh Enviro II inductively coupled plasma-emission spectrometer (ICP-ES), and trace and rare earth elements (REEs) were analyzed using a Sciex Elan 6000 inductively coupled plasma-mass spectrometer (ICP-MS). Because the sample suite included a mix of relatively fresh basalts and intensely altered material containing variable concentrations of $\mathrm{SiO}_{2}, \mathrm{Fe}$, and $\mathrm{S}$, a wide range of standards were run as unknowns to check the quality of the data. The results of these analyses are presented in Appendix Tables 1-3.

\section{RESULTS}

Major-element compositions of all samples are listed by area on the active TAG hydrothermal mound in Table 1. The ICP-ES analyses originally included measurement of loss on ignition (LOI). However, the independent measurements of both $\mathrm{S}$ and $\mathrm{H}_{2} \mathrm{O}^{+}$suggest that concentrations are sufficiently high in some samples for them to be considered major components. Hence, the data have been recalculated, and $\mathrm{S}$ and $\mathrm{H}_{2} \mathrm{O}^{+}$included as an integral part of the major element analyses. Trace element and REE data for the same samples are presented in Tables 2 and 3, respectively. For the following discussion, we divide the samples into two groups based on their mineral assemblages: paragonitized-silicified basalts and clasts, and chloritized basalts.

\section{Paragonitized-Silicified Basalts and Clasts}

This group includes altered basaltic clasts from within the mound (denoted by $\mathrm{C}$ in Tables 1, 2, and 3) and the silicified wallrock and paragonitized-silicified basalt breccias (denoted by $\mathrm{S}$ ) from the upper part of the underlying stockwork. All of these samples have been intensely altered, and, in some cases, original igneous textures have been nearly completely destroyed. They are extremely heterogeneous in nature and are composed of variable mixtures of quartz, pyrite, and paragonite, a microcrystalline Ti-bearing phase, \pm traces of chlorite, and rare anhydrite (Honnorez et al., Chap. 18, this volume). In general, quartz is the most abundant component (estimated to comprise 40-85 vol\%), and pyrite generally varies between 10 and $35 \mathrm{vol} \%$. Paragonite, which comprises from 3 to $30 \mathrm{vol} \%$ of the clasts, is present in much higher concentrations (up to $60 \mathrm{vol} \%$ ) at the base of the paragonitized-silicified basalt breccia zone where it grades into chloritized basalts in Hole 957E. There is a sharp contact between paragonitized-silicified basalts and moderately altered basalts exhibiting chloritized alteration halos in Hole 957M.

The major element compositions reflect the dominance of quartz and pyrite within this group of samples. The more highly silicified samples tend to have less pyrite, as shown by the inverse relation between the $\mathrm{SiO}_{2}$ and $\mathrm{Fe}$ contents (Fig. 3). Compared with relatively fresh basalts from beneath the TAG mound-for example, Samples 158-957M-10R-1 (Pieces 5 and 6) -the paragonitized-silicified ba- 


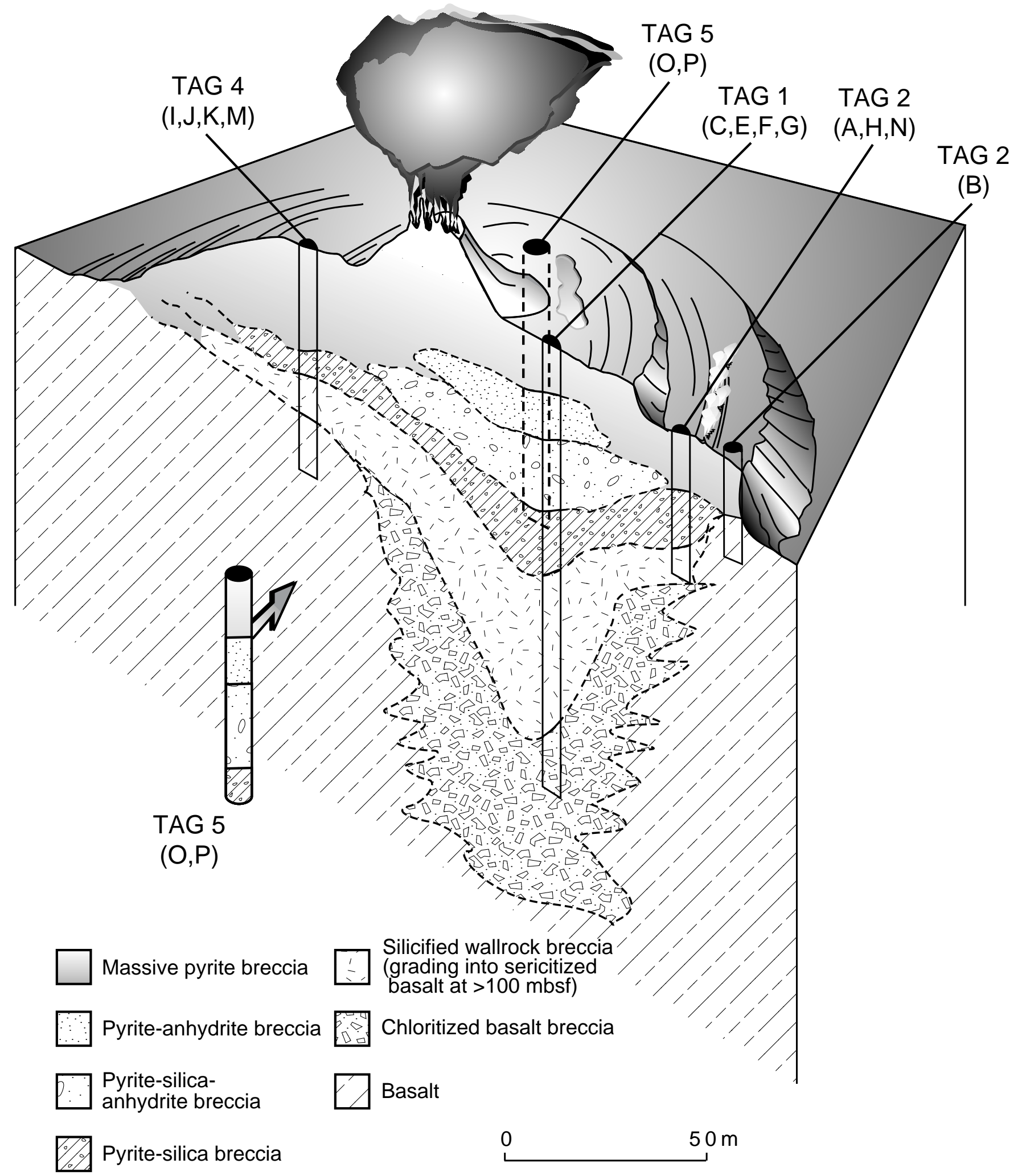

Figure 2. Sketch of the active TAG mound showing the generalized internal stratigraphy and lithologic zones defined by the results from drilling. Letters in parenthesis refer to the drillholes at each area (modified from Humphris et al., 1995). 
Table 1. Major element analyses of altered basalts from clasts within the mound and from the underlying basement at the active TAG hydrothermal mound.

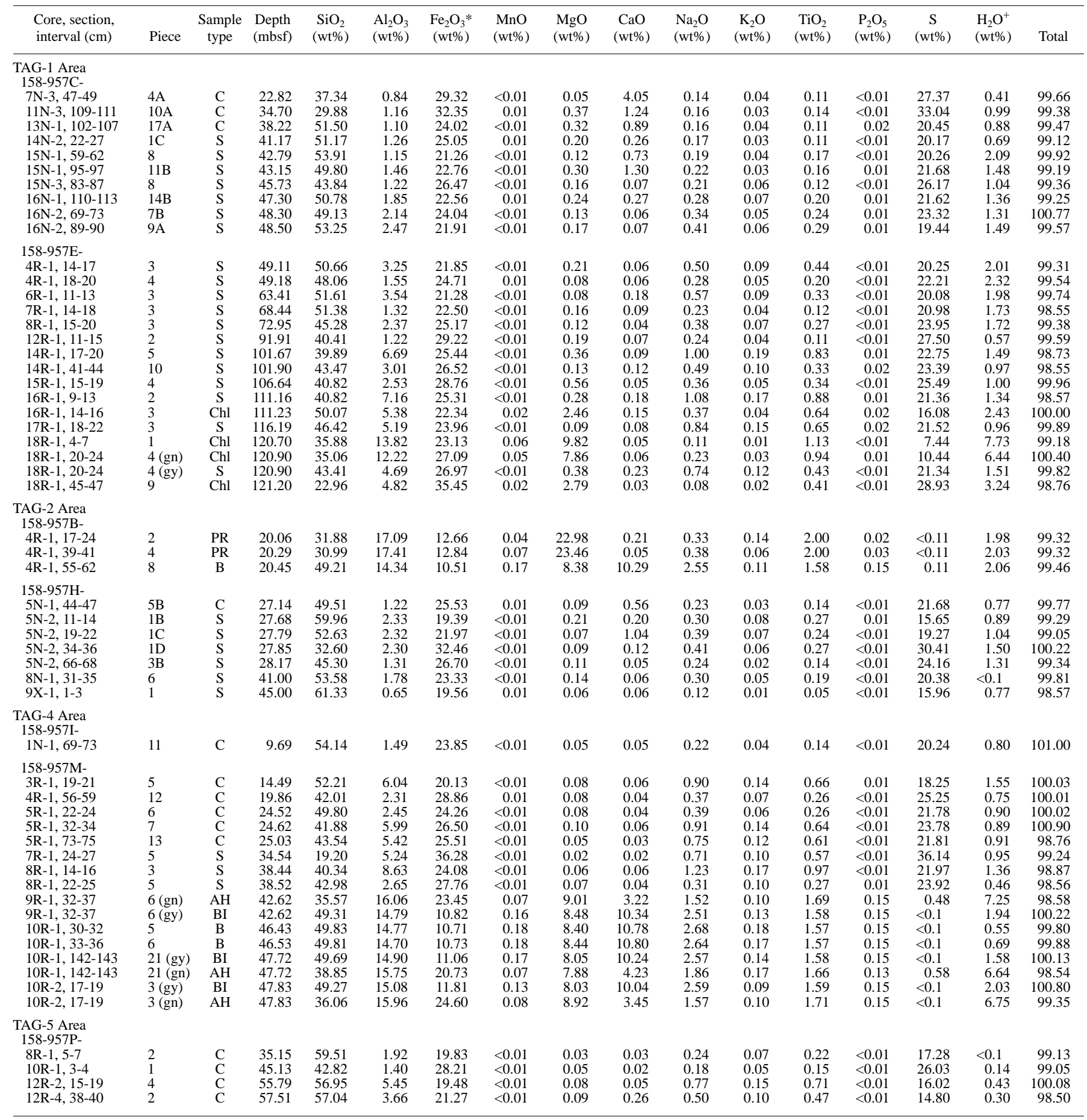

Notes: $\mathrm{Fe}_{2} \mathrm{O}_{3} *$ = total iron as $\mathrm{Fe}_{2} \mathrm{O}_{3} . \mathrm{Gn}=$ green; gy = gray; $\mathrm{C}=$ paragonitized-silicified clast from within the mound; $\mathrm{S}=$ silicified wallrock breccia from underlying stockwork; Chl = chloritized basalt breccia; $\mathrm{PR}=$ hydrothermally altered pillow breccia; $\mathrm{B}=$ relatively fresh basalt; $\mathrm{AH}=$ chloritized alteration halo; $\mathrm{BI}=$ basalt interior. 
Table 2. Trace element analyses of altered basalts from clasts within the mound and from the underlying basement at the active TAG hydrothermal mound.

\begin{tabular}{|c|c|c|c|c|c|c|c|c|c|c|c|c|c|c|c|}
\hline $\begin{array}{l}\text { Core, section, } \\
\text { interval }(\mathrm{cm})\end{array}$ & Piece & $\begin{array}{c}\text { Sample } \\
\text { type }\end{array}$ & $\begin{array}{l}\text { Depth } \\
\text { (mbsf) }\end{array}$ & $\begin{array}{c}\mathrm{Ba} \\
(\mathrm{ppm})\end{array}$ & $\begin{array}{c}\mathrm{Sr} \\
(\mathrm{ppm})\end{array}$ & $\begin{array}{c}\mathrm{Rb} \\
(\mathrm{ppm})\end{array}$ & $\begin{array}{c}\mathrm{V} \\
(\mathrm{ppm})\end{array}$ & $\begin{array}{c}\text { Co } \\
(\mathrm{ppm})\end{array}$ & $\begin{array}{c}\mathrm{Ni} \\
(\mathrm{ppm})\end{array}$ & $\begin{array}{c}\mathrm{Cu} \\
(\mathrm{ppm})\end{array}$ & $\begin{array}{c}\mathrm{Zn} \\
(\mathrm{ppm})\end{array}$ & $\begin{array}{c}\mathrm{Sc} \\
(\mathrm{ppm})\end{array}$ & $\begin{array}{c}\mathrm{Zr} \\
(\mathrm{ppm})\end{array}$ & $\begin{array}{c}\mathrm{Y} \\
(\mathrm{ppm})\end{array}$ & $\begin{array}{l}\mathrm{Nb} \\
(\mathrm{ppm})\end{array}$ \\
\hline \multicolumn{16}{|l|}{ TAG-1 Area } \\
\hline $7 \mathrm{~N}-3,47-49$ & $4 \mathrm{~A}$ & $\mathrm{C}$ & 22.82 & 9 & 187 & 0.47 & 11 & 188.1 & $<5$ & 413 & 12 & 3 & 18 & 1.1 & 0.74 \\
\hline $11 \mathrm{~N}-3,109-111$ & $10 \mathrm{~A}$ & $\mathrm{C}$ & 34.70 & 17 & 73 & 0.61 & 16 & 308.8 & 24 & $<5$ & 20 & 3 & 24 & 1.5 & 0.62 \\
\hline $13 \mathrm{~N}-1,102-107$ & $17 \mathrm{~A}$ & $\mathrm{C}$ & 38.22 & 10 & 36 & 0.72 & 13 & 183.7 & 8 & 162 & 55 & 10 & 19 & 2 & 0.91 \\
\hline $14 \mathrm{~N}-2,22-27$ & $1 \mathrm{C}$ & $\mathrm{S}$ & 41.17 & 7 & 19 & 0.27 & 17 & 160.3 & 13 & 8 & 40 & $<1$ & 14 & 1.3 & 0.35 \\
\hline $15 \mathrm{~N}-1,59-62$ & 8 & $\mathrm{~s}$ & 42.79 & 7 & 40 & 0.51 & 19 & 156.3 & $<5$ & 11 & 63 & 2 & 17 & 2.2 & 0.34 \\
\hline $15 \mathrm{~N}-1,95-97$ & $11 \mathrm{~B}$ & S & 43.15 & 7 & 67 & 0.19 & 31 & 121.7 & $<5$ & 32 & 71 & 2 & 16 & 2.5 & 0.27 \\
\hline $15 \mathrm{~N}-3,83-87$ & 8 & $\mathrm{~S}$ & 45.73 & 12 & 11 & 1.49 & 18 & 299.6 & 24 & 8 & 24 & 1 & 17 & 1.8 & 0.39 \\
\hline $16 \mathrm{~N}-1,110-113$ & $14 \mathrm{~B}$ & $\mathrm{~s}$ & 47.30 & 15 & 53 & 12.75 & 34 & 176.6 & 45 & 15 & $<5$ & 3 & 18 & 7.3 & 9.33 \\
\hline $16 \mathrm{~N}-2,69-73$ & $7 \mathrm{~B}$ & $\mathrm{~S}$ & 48.30 & 8 & 17 & 1.04 & 44 & 84.9 & $<5$ & $<5$ & 7 & 3 & 15 & 2.6 & 0.20 \\
\hline $16 \mathrm{~N}-2,89-90$ & $9 \mathrm{~A}$ & $\mathrm{~s}$ & 48.50 & 11 & 49 & 10.18 & 49 & 188.3 & 69 & $<5$ & $<5$ & 4 & 19 & 7.1 & 8.89 \\
\hline $\begin{array}{l}\text { 158-957E- } \\
4 \mathrm{R}-1,14-17\end{array}$ & 3 & & 4911 & & & & & & & & & & & & \\
\hline $\begin{array}{l}4 \mathrm{R}-1,14-17 \\
4 \mathrm{R}-1,18-20\end{array}$ & $\begin{array}{l}3 \\
4\end{array}$ & $\begin{array}{l}\mathrm{S} \\
\mathrm{S}\end{array}$ & $\begin{array}{l}49.11 \\
49.18\end{array}$ & $\begin{array}{l}12 \\
11\end{array}$ & $\begin{array}{l}26 \\
15\end{array}$ & $\begin{array}{l}0.95 \\
0.74\end{array}$ & $\begin{array}{l}64 \\
27\end{array}$ & $\begin{array}{l}208.4 \\
266.6\end{array}$ & $\begin{array}{l}26 \\
31\end{array}$ & $\begin{array}{l}14 \\
<5\end{array}$ & $\begin{array}{l}14 \\
10\end{array}$ & $\begin{array}{l}7 \\
2\end{array}$ & $\begin{array}{l}25 \\
17\end{array}$ & $\begin{array}{l}6.7 \\
2.7\end{array}$ & $\begin{array}{l}0.30 \\
0.17\end{array}$ \\
\hline $6 \mathrm{R}-1,11-13$ & 3 & $\mathrm{~s}$ & 63.41 & 12 & 36 & 0.49 & 61 & 170.0 & $<5$ & $<5$ & 7 & 6 & 20 & 4.4 & 0.16 \\
\hline $7 \mathrm{R}-1,14-18$ & 3 & S & $\begin{array}{l}68.44 \\
68.44\end{array}$ & 8 & 13 & 0.28 & 17 & 283.6 & 13 & 15 & 19 & 1 & 14 & $\begin{array}{l}.4 .5 \\
\end{array}$ & 0.19 \\
\hline $8 \mathrm{R}-1,15-20$ & 3 & $\mathrm{~S}$ & 72.95 & 9 & 18 & 0.43 & 42 & 268.9 & 6 & 60 & 35 & 4 & 21 & 3.6 & 0.19 \\
\hline $12 \mathrm{R}-1,11-15$ & 2 & $\mathrm{~S}$ & 91.91 & 9 & 12 & 0.45 & 11 & 267.2 & 8 & $<5$ & 151 & $<1$ & 17 & 3.6 & 0.46 \\
\hline $14 \mathrm{R}-1,17-20$ & 5 & $\mathrm{~S}$ & 101.67 & 22 & 79 & 0.86 & 119 & 393.1 & 48 & $<5$ & 51 & 18 & 47 & 16.1 & 0.65 \\
\hline $14 \mathrm{R}-1,41-44$ & 10 & S & 101.90 & 13 & 34 & 0.90 & 57 & 228.3 & 33 & $<5$ & 15 & 6 & 24 & 6.5 & 0.33 \\
\hline $15 \mathrm{R}-1,15-19$ & 4 & $\mathrm{~S}$ & 106.64 & 9 & 18 & 0.36 & 40 & 292.9 & 16 & $<5$ & 16 & 5 & 52 & 45.3 & 0.18 \\
\hline $16 \mathrm{R}-1,9-13$ & 2 & $\mathrm{~S}$ & 111.16 & 18 & 65 & 0.49 & 141 & 247.8 & 15 & 16 & 25 & 18 & 57 & 14.5 & 0.68 \\
\hline $16 \mathrm{R}-1,14-16$ & 3 & $\mathrm{Chl}$ & 111.23 & 7 & 22 & 0.17 & 119 & 209.3 & 22 & $<5$ & 37 & 14 & 85 & 14.5 & 0.40 \\
\hline $17 \mathrm{R}-1,18-22$ & 3 & $\mathrm{~S}$ & 116.19 & 15 & 48 & 1.34 & 94 & 289.8 & 24 & $<5$ & $<5$ & 13 & 36 & 10.9 & 0.35 \\
\hline $18 \mathrm{R}-1,4-7$ & 1 & Chl & 120.70 & 3 & 3 & 0.28 & 271 & 149.5 & 62 & $<5$ & 13 & 35 & 66 & 25.7 & 1.50 \\
\hline $18 \mathrm{R}-1,20-24$ & 4 (gn) & $\mathrm{Chl}$ & 120.90 & 6 & 8 & 0.28 & 250 & 180.4 & 55 & $<5$ & 14 & 30 & 79 & 20.3 & 1.18 \\
\hline $18 \mathrm{R}-1,20-24$ & $4(\mathrm{gy})$ & $\mathrm{S}$ & 120.90 & 14 & 47 & 2.18 & 77 & 341.9 & 45 & 40 & 36 & 16 & 30 & 7.8 & 0.78 \\
\hline $18 \mathrm{R}-1,45-47$ & $9^{(8)}$ & Chl & 121.20 & 8 & 6 & 0.78 & 101 & 405.2 & 24 & 60 & 75 & 12 & 34 & 12.8 & 0.72 \\
\hline \multicolumn{16}{|l|}{$\begin{array}{l}\text { TAG-2 Area } \\
158-957 \mathrm{~B}-\end{array}$} \\
\hline $\begin{array}{l}\text { 158-957B- } \\
4 \mathrm{R}-1,17-24\end{array}$ & 2 & PR & 20.06 & 4 & 13 & 0.83 & 319 & 58.1 & 200 & 14 & 105 & 49 & 123 & 44.4 & 4.34 \\
\hline $4 \mathrm{R}-1,39-41$ & 4 & $\mathrm{PR}$ & 20.29 & 1 & 9 & 0.39 & 380 & 54.5 & 204 & $<5$ & 233 & 48 & 119 & 41.7 & 3.65 \\
\hline $4 \mathrm{R}-1,55-62$ & 8 & $\mathrm{~B}$ & 20.45 & 7 & 116 & 0.70 & 295 & 114.4 & 152 & 92 & 83 & 39 & 96 & 34 & 3.52 \\
\hline \multicolumn{16}{|l|}{$158-957 \mathrm{H}-$} \\
\hline $5 \mathrm{~N}-1,44-47$ & $5 \mathrm{~B}$ & $\mathrm{C}$ & 27.14 & 8 & 31 & 0.41 & 16 & 147.9 & 31 & 30 & 16 & 2 & 15 & 2 & 0.07 \\
\hline $5 \mathrm{~N}-2,11-14$ & $1 \mathrm{~B}$ & S & 27.68 & 5 & 33 & 0.57 & 42 & 162.1 & 53 & $<5$ & 86 & 5 & 24 & 4.6 & 0.50 \\
\hline $5 \mathrm{~N}-2,19-22$ & $1 \mathrm{C}$ & S & 27.79 & 10 & 88 & 0.89 & 48 & 137.0 & 26 & $<5$ & 160 & 4 & 18 & 3 & 0.10 \\
\hline $5 \mathrm{~N}-2,34-36$ & $1 \mathrm{D}$ & $\mathrm{S}$ & 27.85 & 17 & 21 & 0.37 & 50 & 260.3 & 23 & $<5$ & 24 & 3 & 23 & 3 & 0.12 \\
\hline $5 \mathrm{~N}-2,66-68$ & $3 \mathrm{~B}$ & $\mathrm{~S}$ & 28.17 & 8 & 9 & 0.72 & 19 & 273.4 & 25 & $<5$ & 83 & 1 & 18 & 2.2 & 0.05 \\
\hline $8 \mathrm{~N}-1,31-35$ & 6 & S & 41.00 & 8 & 12 & 0.44 & 30 & 207.4 & 18 & $<53$ & 63 & 1 & 6 & 2.5 & 0.07 \\
\hline $9 \mathrm{X}-1,1-3$ & 1 & S & 45.00 & 6 & 6 & 0.50 & 3 & 184.9 & 35 & 117 & 17 & $<1$ & 9 & 0.9 & $<0.05$ \\
\hline \multicolumn{16}{|l|}{$\begin{array}{l}\text { TAG-4 Area } \\
\text { 158-957- }\end{array}$} \\
\hline $\begin{array}{l}158-957 \mathrm{I}- \\
1 \mathrm{~N}-1,69-73\end{array}$ & 11 & $\mathrm{C}$ & 9.69 & 6 & 7 & 0.43 & 27 & 157.5 & 6 & 155 & 888 & 1 & 12 & 1.2 & $<0.05$ \\
\hline $158-957 \mathrm{M}-$ & & & & & & & & & & & & & & & \\
\hline $3 \mathrm{R}-1,19-21$ & 5 & $\mathrm{C}$ & 14.49 & 13 & 40 & 1.00 & 115 & 107.7 & 18 & $<5$ & 799 & 15 & 34 & 7.8 & 0.60 \\
\hline $4 \mathrm{R}-1,56-59$ & 12 & $\mathrm{C}$ & 19.86 & 13 & 13 & 0.61 & 42 & 262.4 & 42 & 38 & 24 & 3 & 21 & 2.4 & 0.14 \\
\hline $5 \mathrm{R}-1,22-24$ & 6 & C & 24.52 & 8 & 13 & 0.20 & 46 & 122.5 & 19 & 10 & 57 & 4 & 19 & 3.7 & 0.06 \\
\hline $5 \mathrm{R}-1,32-34$ & 7 & $\mathrm{C}$ & 24.62 & 14 & 38 & 0.75 & 122 & 156.0 & 42 & $<5$ & 45 & 15 & 35 & 7.4 & 0.43 \\
\hline $5 \mathrm{R}-1,73-75$ & 13 & C & 25.03 & 9 & 35 & 0.60 & 105 & 234.4 & 79 & $<5$ & 75 & 13 & 48 & 6.8 & 1.14 \\
\hline $7 \mathrm{R}-1,24-27$ & 5 & $\mathrm{~S}$ & 34.54 & 15 & 39 & 0.39 & 133 & 211.0 & 71 & $<5$ & 231 & 14 & 54 & 11.2 & 1.14 \\
\hline $8 \mathrm{R}-1,14-16$ & 3 & $\mathrm{~S}$ & 38.44 & 15 & 56 & 0.71 & 186 & 252.0 & 96 & $<5$ & 238 & 25 & 75 & 18.7 & 1.90 \\
\hline $8 \mathrm{R}-1,22-25$ & 5 & $\mathrm{~S}$ & 38.52 & 12 & 10 & 1.07 & 52 & 34.23 & 5 & $<5$ & 88 & 6 & 29 & 7.4 & 0.55 \\
\hline $9 \mathrm{R}-1,32-37$ & $6(\mathrm{gn})$ & $\mathrm{AH}$ & 42.62 & 6 & 62 & 1.23 & 324 & 47.4 & 174 & 148 & 1016 & 42 & 110 & 36.1 & 3.24 \\
\hline $9 \mathrm{R}-1,32-37$ & $6(\mathrm{gy})$ & BI & 42.62 & 5 & 111 & 1.41 & 302 & 52.1 & 144 & 66 & 128 & 42 & 98 & 33.8 & 2.84 \\
\hline $10 \mathrm{R}-1,30-32$ & 5 & B & 46.43 & 9 & 118 & 1.45 & 300 & 60.6 & 135 & 64 & 62 & 43 & 99 & 34.8 & 1.57 \\
\hline $10 \mathrm{R}-1,33-36$ & 6 & $\mathrm{~B}$ & 46.53 & 9 & 124 & 1.93 & 299 & 59.7 & 148 & 69 & 66 & 40 & 98 & 35.5 & 3.06 \\
\hline $10 \mathrm{R}-1,142-143$ & 21 (gy) & BI & 47.72 & 7 & 117 & 1.28 & 302 & 56.6 & 156 & 77 & 389 & 42 & 100 & 35.3 & 3.37 \\
\hline $10 \mathrm{R}-1,142-143$ & 21 (gn) & $\mathrm{AH}$ & 47.72 & 5 & 144 & 0.79 & 319 & 55.3 & 145 & 89 & 7238 & 43 & 107 & 37.3 & 3.86 \\
\hline $10 \mathrm{R}-2,17-19$ & $3(\mathrm{gy})$ & BI & 47.83 & 5 & 118 & 0.84 & 306 & 74.1 & 136 & 70 & 343 & 43 & 99 & 34.4 & 3.17 \\
\hline $10 \mathrm{R}-2,17-19$ & 3 (gn) & $\mathrm{AH}$ & 47.83 & 4 & 77 & 1.52 & 321 & 55.7 & 153 & 109 & 1558 & 42 & 110 & 38.1 & 3.54 \\
\hline \multirow{2}{*}{\multicolumn{16}{|c|}{$\begin{array}{l}\text { TAG-5 Area } \\
\text { 158-957P- }\end{array}$}} \\
\hline & & & 35.15 & 4 & 15 & 0.84 & 32 & 268.9 & 27 & $<5$ & 29 & 4 & 22 & 2.8 & 0.37 \\
\hline $10 \mathrm{R}-1,3-4$ & 1 & C & 45.13 & 6 & 15 & 0.46 & 23 & 292.7 & 12 & $<5$ & 85 & 2 & 19 & 2 & 0.25 \\
\hline $12 \mathrm{R}-2,15-19$ & 4 & $\mathrm{C}$ & 55.79 & 11 & 41 & 0.94 & 103 & 266.8 & 34 & $<5$ & $<5$ & 15 & 52 & 9.6 & 0.78 \\
\hline $12 \mathrm{R}-4,38-40$ & 2 & $\mathrm{C}$ & 57.51 & 8 & 39 & 0.59 & 65 & 266.6 & 47 & $<5$ & 9 & 10 & 36 & 13 & 0.62 \\
\hline
\end{tabular}

Notes: $\mathrm{Ba}, \mathrm{V}$, and Sc determined by ICP-ES; all other elements analyzed by ICP-MS. $\mathrm{Gn}=$ green; gy = gray; $\mathrm{C}=$ paragonitized-silicified clast from within the mound; $\mathrm{S}=$ silicified wallrock breccia from underlying stockwork; $\mathrm{Chl}=$ chloritized basalt breccia; $\mathrm{PR}=$ hydrothermally altered pillow breccia; $\mathrm{B}=$ relatively fresh basalt; $\mathrm{AH}=\mathrm{chloritized}$ alteration halo; BI = basalt interior. 
Table 3. REE element analyses of altered basalts from clasts within the mound and from the underlying basement at the active TAG hydrothermal mound.

\begin{tabular}{|c|c|c|c|c|c|c|c|c|c|c|c|c|c|c|c|c|c|c|}
\hline $\begin{array}{l}\text { Core, section, } \\
\text { interval }(\mathrm{cm})\end{array}$ & Piece & $\begin{array}{c}\text { Sample } \\
\text { type }\end{array}$ & $\begin{array}{l}\text { Depth } \\
\text { (mbsf) }\end{array}$ & $\begin{array}{c}\mathrm{La} \\
(\mathrm{ppm})\end{array}$ & $\begin{array}{c}\mathrm{Ce} \\
(\mathrm{ppm})\end{array}$ & $\begin{array}{c}\mathrm{Pr} \\
(\mathrm{ppm})\end{array}$ & $\begin{array}{c}\mathrm{Nd} \\
(\mathrm{ppm})\end{array}$ & $\begin{array}{c}\text { Sm } \\
(\mathrm{ppm})\end{array}$ & $\begin{array}{c}\mathrm{Eu} \\
(\mathrm{ppm})\end{array}$ & $\begin{array}{c}\mathrm{Gd} \\
(\mathrm{ppm})\end{array}$ & $\begin{array}{c}\mathrm{Tb} \\
(\mathrm{ppm})\end{array}$ & $\begin{array}{c}\text { Dy } \\
(\mathrm{ppm})\end{array}$ & $\begin{array}{c}\mathrm{Ho} \\
(\mathrm{ppm})\end{array}$ & $\begin{array}{c}\mathrm{Er} \\
(\mathrm{ppm})\end{array}$ & $\begin{array}{c}\mathrm{Tm} \\
(\mathrm{ppm})\end{array}$ & $\begin{array}{c}\mathrm{Yb} \\
(\mathrm{ppm})\end{array}$ & $\begin{array}{c}\mathrm{Lu} \\
(\mathrm{ppm})\end{array}$ & $\begin{array}{c}\mathrm{Hf} \\
(\mathrm{ppm})\end{array}$ \\
\hline \multicolumn{19}{|l|}{$\begin{array}{l}\text { TAG-1 Area } \\
158-957 \mathrm{C}-\end{array}$} \\
\hline $7 \mathrm{~N}-3,47-49$ & $4 \mathrm{~A}$ & $\mathrm{C}$ & 22.82 & 0.36 & 0.70 & 0.08 & 0.41 & 0.10 & 0.07 & 0.14 & 0.03 & 0.16 & 0.03 & 0.14 & 0.02 & 0.16 & 0.02 & 0.31 \\
\hline $11 \mathrm{~N}-3,109-111$ & $10 \mathrm{~A}$ & $\mathrm{C}$ & 34.70 & 0.54 & 1.24 & 0.13 & 0.69 & 0.18 & 0.07 & 0.21 & 0.04 & 0.24 & 0.06 & 0.19 & 0.04 & 0.22 & 0.03 & 0.28 \\
\hline $13 \mathrm{~N}-1,102-107$ & $17 \mathrm{~A}$ & C & 38.22 & 0.65 & 1.54 & 0.19 & 1.18 & 0.36 & 0.17 & 0.32 & 0.05 & 0.30 & 0.06 & 0.18 & 0.02 & 0.17 & 0.02 & 0.13 \\
\hline $14 \mathrm{~N}-2,22-27$ & $1 \mathrm{C}$ & s & 41.17 & 0.41 & 0.93 & 0.10 & 0.56 & 0.20 & 0.08 & 0.16 & 0.03 & 0.18 & 0.04 & 0.14 & 0.02 & 0.15 & 0.03 & 0.21 \\
\hline $15 \mathrm{~N}-1,59-62$ & 8 & $\mathrm{~S}$ & 42.79 & 0.51 & 1.53 & 0.22 & 1.30 & 0.41 & 0.21 & 0.37 & 0.07 & 0.37 & 0.07 & 0.24 & 0.04 & 0.26 & 0.04 & 0.29 \\
\hline $15 \mathrm{~N}-1,95-97$ & $11 \mathrm{~B}$ & $\mathrm{~S}$ & 43.15 & 0.44 & 1.34 & 0.17 & 1.12 & 0.32 & 0.22 & 0.36 & 0.07 & 0.40 & 0.08 & 0.26 & 0.04 & 0.30 & 0.04 & 0.25 \\
\hline $15 \mathrm{~N}-3,83-87$ & 8 & $\mathrm{~S}$ & 45.73 & 0.88 & 2.06 & 0.21 & 1.10 & 0.32 & 0.10 & 0.27 & 0.06 & 0.32 & 0.06 & 0.21 & 0.03 & 0.25 & 0.03 & 0.26 \\
\hline $16 \mathrm{~N}-1,110-113$ & $14 \mathrm{~B}$ & $\mathrm{~S}$ & 47.30 & 2.73 & 4.78 & 0.40 & 1.24 & 0.80 & 0.14 & 0.59 & 0.12 & 0.36 & 0.30 & 0.36 & 0.12 & 0.52 & 0.04 & 1.36 \\
\hline $16 \mathrm{~N}-2,69-73$ & 7B & S & 48.30 & 0.54 & 1.34 & 0.15 & 0.81 & 0.24 & 0.08 & 0.30 & 0.06 & 0.41 & 0.08 & 0.31 & 0.05 & 0.34 & 0.05 & 0.27 \\
\hline $16 \mathrm{~N}-2,89-90$ & $9 \mathrm{~A}$ & $\mathrm{~s}$ & 48.50 & 2.28 & 3.43 & 0.37 & 2.61 & 0.84 & 0.32 & 0.48 & 0.13 & 0.63 & 0.08 & 0.37 & 0.09 & 0.30 & 0.09 & 0.94 \\
\hline 158-957E- & & & & & & & & & & & & & & & & & & \\
\hline $4 \mathrm{R}-1,14-17$ & 3 & S & 49.11 & 0.87 & 2.26 & 0.26 & 1.52 & 0.51 & 0.16 & 0.77 & 0.15 & 1.01 & 0.23 & 0.73 & 0.12 & 0.77 & 0.12 & 0.57 \\
\hline $4 \mathrm{R}-1,18-20$ & 4 & S & 49.18 & 0.73 & 1.76 & 0.19 & 1.00 & 0.25 & 0.09 & 0.33 & 0.06 & 0.43 & 0.09 & 0.30 & 0.06 & 0.36 & 0.05 & 0.26 \\
\hline 6R-1, 11-13 & 3 & S & 63.41 & 0.49 & 1.40 & 0.17 & 0.93 & 0.36 & 0.12 & 0.50 & 0.10 & 0.71 & 0.15 & 0.53 & 0.09 & 0.60 & 0.09 & 0.40 \\
\hline $7 \mathrm{R}-1,14-18$ & 3 & $\mathrm{~S}$ & 68.44 & 0.34 & 0.99 & 0.14 & 0.86 & 0.32 & 0.12 & 0.3 & 0.07 & 0.4 & 0.09 & 0.2 & 0.04 & 0. & 0.04 & 0.18 \\
\hline $8 \mathrm{R}-1,15-2$ & 3 & $\mathrm{~S}$ & 72.95 & 0.49 & 1.45 & 0.18 & 1.12 & 0.35 & 0.10 & 0.4 & 0.1 & 0.5 & 0.12 & 0. & 0.07 & 0. & 0.07 & 0.33 \\
\hline $12 \mathrm{R}-1,11-15$ & 2 & $\mathrm{~S}$ & 91.91 & 0.27 & 0.70 & 0.09 & 0.50 & 0.28 & 0.09 & 0.4 & 0. & 0.5 & 0.13 & 0.3 & 0.06 & 0 & 0.05 & 0.17 \\
\hline $14 \mathrm{R}-1,17-20$ & 5 & S & 101.67 & 1.95 & 5.83 & 0.76 & 4.57 & 1.60 & 0.40 & 2.03 & 0.42 & 2.58 & 0.58 & 1.82 & 0.28 & 1.85 & 0.27 & 1.21 \\
\hline $14 \mathrm{R}-1,41-44$ & 10 & S & 101.90 & 0.90 & 2.72 & 0.36 & 2.25 & 0.75 & 0.30 & 0.94 & 0.18 & 1.14 & 0.24 & 0.73 & 0.12 & 0.73 & 0.11 & 0.36 \\
\hline $15 \mathrm{R}-1,15-19$ & 4 & S & 106.64 & 0.76 & 2.06 & 0.25 & 1.51 & 0.47 & 0.13 & 0.63 & 0.13 & 0.83 & 0.19 & 0.60 & 0.11 & 0.63 & 0.09 & 0.36 \\
\hline $16 \mathrm{R}-1,9-13$ & 2 & $\mathrm{~S}$ & 111.16 & 1.54 & 4.46 & 0.56 & 3.53 & 1.26 & 0.42 & 1.81 & 0.36 & 2.30 & 0.52 & 1.62 & 0.26 & 1.71 & 0.25 & 1.54 \\
\hline $16 \mathrm{R}-1,14-16$ & 3 & $\mathrm{Chl}$ & 111.23 & 1.12 & 3.67 & 0.51 & 3.47 & 1.36 & 0.36 & 1.94 & 0.39 & 2.40 & 0.50 & 1.57 & 0.25 & 1.53 & 0.23 & 2.39 \\
\hline $17 \mathrm{R}-1,18-22$ & 3 & $\mathrm{~S}$ & 116.19 & 1.69 & 4.69 & 0.58 & 3.21 & 1.08 & 0.30 & 1.41 & 0.27 & 1.79 & 0.39 & 1.23 & 0.21 & 1.28 & 0.19 & 0.75 \\
\hline $18 \mathrm{R}-1,4-7$ & 1 & Chl & 120.70 & 2.48 & 7.33 & 0.91 & 5.51 & 2.13 & 0.52 & 3.14 & 0.66 & 4.04 & 0.90 & 2.80 & 0.44 & 2.67 & 0.40 & 1.93 \\
\hline $18 \mathrm{R}-1,20-24$ & 4 (gn) & Chl & 120.90 & 2.40 & 7.33 & 0.94 & 5.72 & 2.03 & 0.45 & 2.73 & 0.54 & 3.41 & 0.74 & 2.28 & 0.37 & 2.22 & 0.31 & 2.21 \\
\hline $18 \mathrm{R}-1,20-24$ & $4(\mathrm{gy})$ & $\mathrm{S}$ & 120.90 & 0.86 & 2.41 & 0.31 & 1.85 & 0.62 & 0.21 & 0.94 & 0.20 & 1.24 & 0.28 & 0.9 & 0.14 & 0.89 & 0.14 & 0.41 \\
\hline $18 \mathrm{R}-1,45-47$ & 9 & Chl & 121.20 & 1.34 & 3.39 & 0.44 & 2.69 & 1.07 & 0.24 & 1.62 & 0.35 & 2.15 & 0.45 & 1.39 & 0.22 & 1.37 & 0.19 & 0.78 \\
\hline \multicolumn{19}{|l|}{$\begin{array}{l}\text { TAG-2 Area } \\
158-957 \mathrm{~B}-\end{array}$} \\
\hline $\begin{array}{c}158-957 \mathrm{~B}- \\
4 \mathrm{R}-1,17-24\end{array}$ & 2 & PR & 20.06 & 3.90 & 12.15 & 1.60 & 10.54 & 4.13 & 1.43 & 6.01 & 1.20 & 7.42 & 1.56 & 4.82 & 0.74 & 4.46 & 0.67 & 3.17 \\
\hline $4 \mathrm{R}-1,39-41$ & 4 & $\mathrm{PR}$ & 20.29 & 4.57 & 14.46 & 1.97 & 12.54 & 4.38 & 1.79 & 5.86 & 1.13 & 6.55 & 1.39 & 4.30 & 0.63 & 4.04 & 0.58 & 3.62 \\
\hline $4 \mathrm{R}-1,55-62$ & 8 & B & 20.45 & 3.35 & 10.65 & 1.46 & 9.62 & 3.66 & 1.20 & 4.71 & 0.93 & 5.50 & 1.17 & 3.50 & 0.53 & 3.31 & 0.49 & 3.73 \\
\hline $158-957 \mathrm{H}-$ & & & & & & & & & & & & & & & & & & \\
\hline $\begin{array}{l}5 \mathrm{~N}-1,44-47 \\
5 \mathrm{~N}-2,11-14\end{array}$ & $\begin{array}{l}5 \mathrm{~B} \\
1 \mathrm{~B}\end{array}$ & $\begin{array}{l}\mathrm{C} \\
\mathrm{S}\end{array}$ & $\begin{array}{l}27.14 \\
27.68\end{array}$ & $\begin{array}{l}0.71 \\
0.59\end{array}$ & $\begin{array}{l}1.66 \\
1.37\end{array}$ & $\begin{array}{l}0.18 \\
0.17\end{array}$ & $\begin{array}{l}0.98 \\
1.08\end{array}$ & $\begin{array}{l}0.26 \\
0.36\end{array}$ & $\begin{array}{l}0.10 \\
0.17\end{array}$ & $\begin{array}{l}0.30 \\
0.60\end{array}$ & $\begin{array}{l}0.05 \\
0.11\end{array}$ & $\begin{array}{l}0.30 \\
0.68\end{array}$ & $\begin{array}{l}0.07 \\
0.15\end{array}$ & $\begin{array}{l}0.20 \\
0.53\end{array}$ & $\begin{array}{l}0.03 \\
0.09\end{array}$ & $\begin{array}{l}0.19 \\
0.52\end{array}$ & $\begin{array}{l}0.03 \\
0.09\end{array}$ & $\begin{array}{l}0.25 \\
0.49\end{array}$ \\
\hline $5 \mathrm{~N}-2,19-22$ & $1 \mathrm{C}$ & S & 27.79 & 0.69 & 1.87 & 0.22 & 1.27 & & 0.2 & 0.42 & 0.0 & 0.4 & 0.10 & 0.3 & 0.05 & 0. & 0.06 & 0.32 \\
\hline $5 \mathrm{~N}-2,34-36$ & 1D & $\mathrm{S}$ & 27.85 & 0.54 & 1.35 & 0.13 & 0.68 & & 0.0 & 0.3 & & 0. & & 0. & 0.0 & & 0.07 & 0.29 \\
\hline $5 \mathrm{~N}-2,66-68$ & $3 \mathrm{~B}$ & S & 28.17 & 0.28 & 0.76 & 0.08 & 0.5 & 0.1 & 0.09 & 0.2 & 0.0 & 0.3 & 0.08 & 0.2 & 0.0 & & 0.04 & 0.21 \\
\hline & 6 & $\mathrm{~S}$ & 41.00 & 0.3 & 0.8 & 0. & 0.5 & & 0.0 & & & 0. & & 0. & 0.0 & & 0.05 & 0.26 \\
\hline $9 \mathrm{X}-1,1-3$ & 1 & S & 45.00 & 0.25 & 0.69 & 0.08 & 0.51 & 0.17 & 0.08 & 0.17 & 0.03 & 0.15 & 0.03 & 0.10 & 0.01 & 0.11 & 0.01 & 0.12 \\
\hline \multicolumn{19}{|l|}{$\begin{array}{l}\text { TAG-4 Area } \\
\text { 158-957I- }\end{array}$} \\
\hline $1 \mathrm{~N}-1,69-73$ & 11 & C & 9.69 & 1.79 & 4.35 & 0.49 & 2.27 & 0.32 & 0.12 & 0.20 & 0.03 & 0.21 & 0.04 & 0.17 & 0.03 & 0.19 & 0.03 & 0.12 \\
\hline $158-957 \mathrm{M}-$ & & & & & & & & & & & & & & & & & & \\
\hline & 5 & C & 14.49 & 0.83 & 2.33 & 0.28 & 1.59 & 0.49 & 0.33 & 0.85 & 0.18 & 1.15 & 0.28 & 0.92 & 0.15 & 1.07 & 0.17 & 1.12 \\
\hline & 12 & C & 19.86 & & 1.23 & & 0.65 & & 0.1 & & & & & & 0.0 & & 0. & 0.30 \\
\hline & 6 & C & 24.52 & 0.59 & 1.56 & & 0.9 & 0.31 & 0.1 & 0. & 0. & 0. & 0.13 & 0. & 0.07 & 0. & 0.0 & 0.24 \\
\hline & 7 & C & & & 2.2 & & 1.5 & & 0.3 & & & 1. & & & 0.1 & & 0. & 1.12 \\
\hline & 13 & $\mathrm{C}$ & & 0. & 2.3 & & 1.5 & & 0.3 & 0. & & 1. & 0.26 & 0. & 0.1 & & 0. & 1.20 \\
\hline & 5 & S & & & 10.8 & & 5.5 & & 0. & 1. & & & 0. & 1. & 0. & & 0. & 1.25 \\
\hline$-1,14-16$ & 3 & S & & 1.4 & 3. & 0.5 & 2.8 & 1.3 & 0. & & & 2. & 0.7 & 2. & 0.3 & 2. & 0.3 & 1.84 \\
\hline $8 \mathrm{R}-1,22-25$ & 5 & $\mathrm{~S}$ & 38.52 & 3.98 & 9.04 & 1.13 & 5.56 & 1.26 & 0.57 & 1.1 & 0.22 & 1.2 & 0.27 & 0.7 & 0.12 & 0.74 & 0.11 & 0.52 \\
\hline $9 \mathrm{R}-1,32-37$ & 6 (gn) & $\mathrm{AH}$ & 42.62 & 4.45 & 11.88 & 1.77 & 10.84 & 3.94 & 1.39 & 5.51 & 1.01 & 5.6 & 1.30 & 3.8 & 0.61 & 3.93 & 0.55 & 2.86 \\
\hline $9 \mathrm{R}-1,32-37$ & $6(\mathrm{gy})$ & $\mathrm{BI}$ & 42.62 & 3.91 & 11.07 & 1.60 & 10.39 & 3.68 & 1.25 & 5.23 & 0.97 & 5.3 & 1.22 & 3.72 & 0.55 & 3.40 & 0.49 & 2.52 \\
\hline 10R-1, 30-32 & 5 & $\mathrm{~B}$ & 46.43 & 3.90 & 11.24 & 1.66 & 10.22 & 3.76 & 1.26 & 5.34 & 0.96 & 5.30 & 1.20 & 3.62 & 0.57 & 3.50 & 0.53 & 1.78 \\
\hline 10R-1,33-36 & 6 & $\mathrm{~B}$ & 46.53 & 4.14 & 11.26 & 1.67 & 10.46 & 3.79 & 1.29 & 5.40 & 0.98 & 5.32 & 1.24 & 3.75 & 0.56 & 3.55 & 0.52 & 2.56 \\
\hline $10 \mathrm{R}-1,142-143$ & 21 (gy) & BI & 47.72 & 4.11 & 11.23 & 1.63 & 10.03 & 3.78 & 1.31 & 5.29 & 0.95 & 5.35 & 1.21 & 3.6 & 0.55 & 3.40 & 0.51 & 2.23 \\
\hline $10 \mathrm{R}-1,142-143$ & $21(\mathrm{gn})$ & $\mathrm{AH}$ & 47.72 & 4.78 & 13.02 & 1.93 & 11.91 & 4.15 & 1.51 & 5.81 & 1.05 & 5.7 & 1.32 & 4.0 & 0.59 & 3.73 & 0.57 & 2.85 \\
\hline $10 \mathrm{R}-2,17-19$ & 3 (gy) & $\mathrm{BI}$ & 47.83 & 3.91 & 11.16 & 1.66 & 10.05 & 3.83 & 1.32 & 5.34 & 0.95 & 5.25 & 1.18 & 3.63 & 0.54 & 3.32 & 0.49 & 2.47 \\
\hline $10 \mathrm{R}-2,17-19$ & $3(\mathrm{gn})$ & $\mathrm{AH}$ & 47.83 & 4.66 & 12.99 & 1.89 & 11.49 & 4.15 & 1.43 & 5.80 & 1.09 & 5.92 & 1.33 & 3.94 & 0.60 & 3.62 & 0.54 & \\
\hline
\end{tabular}




\begin{tabular}{|c|c|c|c|c|c|c|c|c|c|c|c|c|c|c|c|c|c|c|}
\hline $\begin{array}{l}\text { Core, section, } \\
\text { interval }(\mathrm{cm})\end{array}$ & Piece & $\begin{array}{l}\text { Sample } \\
\text { type }\end{array}$ & $\begin{array}{l}\text { Depth } \\
\text { (mbsf) }\end{array}$ & $\begin{array}{c}\mathrm{La} \\
(\mathrm{ppm})\end{array}$ & $\begin{array}{c}\mathrm{Ce} \\
(\mathrm{ppm})\end{array}$ & $\begin{array}{c}\mathrm{Pr} \\
(\mathrm{ppm})\end{array}$ & $\begin{array}{c}\mathrm{Nd} \\
(\mathrm{ppm})\end{array}$ & $\begin{array}{c}\mathrm{Sm} \\
(\mathrm{ppm})\end{array}$ & $\begin{array}{c}\mathrm{Eu} \\
(\mathrm{ppm})\end{array}$ & $\begin{array}{c}\mathrm{Gd} \\
(\mathrm{ppm})\end{array}$ & $\begin{array}{c}\mathrm{Tb} \\
(\mathrm{ppm})\end{array}$ & $\begin{array}{c}\text { Dy } \\
(\mathrm{ppm})\end{array}$ & $\begin{array}{c}\mathrm{Ho} \\
(\mathrm{ppm})\end{array}$ & $\begin{array}{c}\text { Er } \\
(\mathrm{ppm})\end{array}$ & $\begin{array}{c}\mathrm{Tm} \\
(\mathrm{ppm})\end{array}$ & $\begin{array}{c}\mathrm{Yb} \\
(\mathrm{ppm})\end{array}$ & $\begin{array}{c}\mathrm{Lu} \\
(\mathrm{ppm})\end{array}$ & $\begin{array}{c}\mathrm{Hf} \\
(\mathrm{ppm})\end{array}$ \\
\hline \multicolumn{19}{|l|}{$\begin{array}{l}\text { TAG-5 Area } \\
\text { 158-957P- }\end{array}$} \\
\hline $8 \mathrm{R}-1,5-7$ & 2 & C & 35.15 & 0.26 & 0.67 & 0.08 & 0.44 & 0.17 & 0.05 & 0.24 & 0.06 & 0.36 & 0.10 & 0.34 & 0.06 & 0.40 & 0.07 & 0.42 \\
\hline 10R-1, 3-4 & 1 & C & 45.13 & 0.30 & 0.79 & 0.10 & 0.64 & 0.16 & 0.09 & 0.24 & 0.07 & 0.30 & 0.07 & 0.26 & 0.04 & 0.27 & 0.05 & 0.34 \\
\hline $12 \mathrm{R}-2,15-19$ & 4 & C & 55.79 & 1.15 & 2.97 & 0.38 & 1.95 & 0.64 & 0.20 & 0.98 & 0.21 & 1.19 & 0.34 & 1.08 & 0.19 & 1.16 & 0.21 & 1.23 \\
\hline $12 \mathrm{R}-4,38-40$ & 2 & $\mathrm{C}$ & 57.51 & 1.14 & 3.29 & 0.52 & 3.41 & 1.50 & 0.63 & 2.33 & 0.41 & 1.97 & 0.45 & 1.27 & 0.20 & 1.19 & 0.18 & 0.87 \\
\hline
\end{tabular}

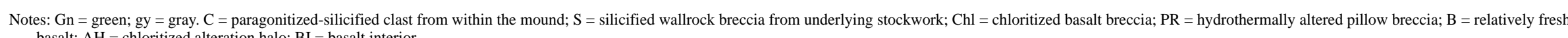
basalt; $\mathrm{AH}=$ chloritized alteration halo; $\mathrm{BI}=$ basalt interior. 
salts and clasts exhibit high concentrations of total $\mathrm{Fe}$ (19.39-36.28 wt $\%$ as $\mathrm{Fe}_{2} \mathrm{O}_{3}$ ) and $\mathrm{S}\left(14.80-36.14 \mathrm{wt} \%\right.$ ), and concentrations of $\mathrm{SiO}_{2}$ that vary from being considerably lower (down to $19.20 \mathrm{wt} \%$ ) to much higher (61.33 wt\%) than in fresh basalts. Most other major elements, including $\mathrm{Al}_{2} \mathrm{O}_{3}, \mathrm{MgO}, \mathrm{CaO}, \mathrm{Na}_{2} \mathrm{O}$, and $\mathrm{TiO}_{2}$, show significantly lower concentrations compared with fresh material, although much of this depletion may be a dilution effect caused by the addition of $\mathrm{S}$ and $\mathrm{Fe}$ (this is discussed in a later section). $\mathrm{Na}_{2} \mathrm{O}, \mathrm{K}_{2} \mathrm{O}$, and $\mathrm{TiO}_{2}$ contents covary with $\mathrm{Al}_{2} \mathrm{O}_{3}$ (Fig. 3); this is a reflection of dilution of the paragonite and Ti-bearing phase (resulting from alteration of the basalt) by quartz and pyrite (which are hydrothermal precipitates). $\mathrm{MgO}$ concentrations are extremely low $(<0.6 \mathrm{wt} \%)$ in all of these samples. $\mathrm{CaO}$ contents are also generally very low $(<0.3 \mathrm{wt} \%)$ except in a few samples. At TAG-1, three clast samples-Samples 158957C-7N-3 (Piece 4A) from 22.82 mbsf, 158-957C-11N-3 (Piece $10 \mathrm{~A}$ ) from $34.70 \mathrm{mbsf}$, and $158-957 \mathrm{C}-13 \mathrm{~N}-1$ (Piece 17A) from 38.22 mbsf-show high $\mathrm{CaO}$ concentrations ranging from 0.89 to 4.05 $\mathrm{wt} \%$. These samples were all taken from the anhydrite-rich zone beneath the mound and, although every effort was made to avoid veined material, they contain very fine anhydrite veins. Such a vein network is visible within Sample 158-957C-7N-3 (Piece 4A), which has the highest $\mathrm{CaO}$ content of $4.05 \mathrm{wt} \%$, and is estimated to make up about $5 \mathrm{vol} \%$ of the rock. Traces of anhydrite were also identified in Sample 957C-11N-3 (Piece 10A). Within the paragonitized-silicified basalt breccia zone, two samples-Samples 158-957C-15N-1 (Pieces 8 and $11 \mathrm{~B}$ ) — show extensive fine veining and were taken close and adjacent (respectively) to a large anhydrite vein; consequently, their high $\mathrm{CaO}$ contents reflect the presence of anhydrite. Although an an- hydrite-rich zone does not occur in the TAG-2 area, late anhydrite veins are present and can account for the high concentrations of $\mathrm{CaO}$ (0.58 and $1.04 \mathrm{wt} \%$ ) in Samples 158-957H-5N-1 (Piece 5B; 27.14 mbsf) and 5N-2 (Piece 1C; 27.79 mbsf), respectively.

Significant differences in the concentrations of the trace elements in comparison with fresh basalts are also observed. The concentrations of $\mathrm{V}, \mathrm{Ni}, \mathrm{Cu}, \mathrm{Sc}, \mathrm{Y}$, and $\mathrm{Zr}$ are significantly lower than those in fresh basalts. $\mathrm{Sr}$ contents are also generally lower, except in those samples where small to trace amounts of anhydrite occur. The concentration of $\mathrm{Ba}$ is highly variable (4-22 ppm), but shows some covariation with $\mathrm{Al}_{2} \mathrm{O}_{3}$, particularly in the more paragonitized samples $\left(\mathrm{Al}_{2} \mathrm{O}_{3}\right.$ contents $>4 \mathrm{wt} \%$; Fig. 3$)$. This suggests that its concentration is at least partially controlled by substitution for $\mathrm{Na}$ and/or $\mathrm{K}$ in paragonite. $\mathrm{Zn}$ concentrations are also highly variable, typically ranging from $<5 \mathrm{ppm}$ to $86 \mathrm{ppm}$, although a few samples have values as high as $238 \mathrm{ppm}$. However, in the TAG-4 area, two clasts (Samples 158957I-1N-1, Piece 11, and 158-957M-3R-1, Piece 5) from 9.69 and 14.49 mbsf, show extremely high concentrations of 888 and 799 ppm, respectively. These clasts occur within a zone of pyrite breccias with minor sphalerite in veins cutting through the breccias and filling cavities, suggesting lower temperature upflow in this area. In addition, thin-section descriptions of samples from this zone indicate the presence of small $(20 \mu \mathrm{m})$ inclusions of sphalerite within pyrite grains (Humphris, Herzig, Miller, et al., 1996).

Examples of the chondrite-normalized REE patterns for paragonitized-silicified basalt breccias and clasts are shown in Figure 4. Samples were selected to represent the range in modal mineralogy and major element composition observed for each group. In almost
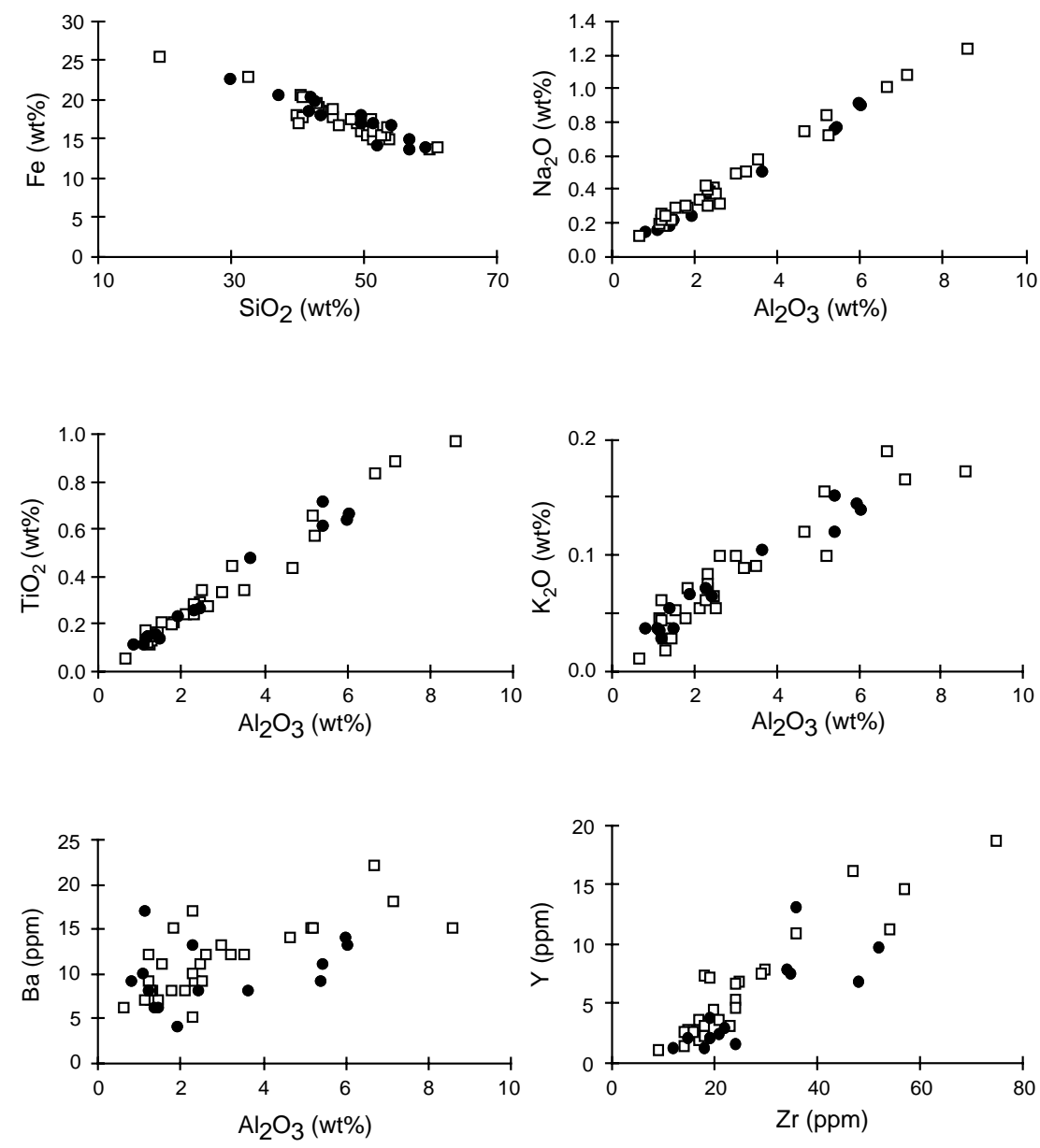

Figure 3. Covariation diagrams of selected major and trace elements for altered basaltic clasts from within the mound (solid circles) and for silicified wallrock and paragonitized-silicified basalt breccias (open squares) from the upper part of the underlying stockwork. 
all cases, the REE concentrations are lower than those in the fresh basalts, and in a few samples, a small positive Eu anomaly has developed during alteration. In general, the degree to which the REE concentrations are lowered is correlated with the extent of silicification of the rock (i.e., the less paragonite and the more quartz, the lower the REE contents). The sample with the most depleted chondrite-normalized REE pattern relative to fresh basalt-Sample 158-957H-9X-1 (Piece $1,103 \mathrm{~cm}$ ) - has the highest $\mathrm{SiO}_{2}$ content $(61.33 \mathrm{wt} \%$ ) and the lowest $\mathrm{Al}_{2} \mathrm{O}_{3}$ content $(0.65 \mathrm{wt} \%)$; the concentrations of these oxides then decrease and increase respectively to values of 40.34 and 8.63 wt\% in Sample 158-957M-8R-1 (Piece 3, 14-16 cm), which has the least depleted chondrite-normalized REE pattern for these sample types.

\section{Chloritized Basalts}

This group includes the chloritized basalts (denoted by $\mathrm{Chl}$ in Tables 1, 2, and 3) from the lower part of Hole 957E (in the TAG-1 area), the hydrothermally altered pillow breccia (denoted by PR from Hole 957B) in the TAG-2 area, and the chlorite-rich halos (denoted by $\mathrm{AH}$ ) on basalts from the TAG-4 areas. Although all of these samples are "chloritized," they show different geochemical trends that reflect different mineral chemistry and different alteration processes. Figure 5 shows the variations in major element concentrations grouped according to sample type and plotted against $\mathrm{H}_{2} \mathrm{O}^{+}$content as an indicator of the extent of alteration. These are compared with the basalts and basalt interiors (denoted by $\mathrm{B}$ and $\mathrm{BI}$ ) from the edges of the mound (in the TAG-2 and TAG-4 areas). Some of these relatively fresh samples contain up to $2.06 \mathrm{wt} \% \mathrm{H}_{2} \mathrm{O}^{+}$and show early stages of low-temperature alteration to smectite. However, others are isotopically unaltered (Alt and Teagle, Chap. 21, this volume; Teagle et al., Chap. 22, this volume, so these samples provide the most useful
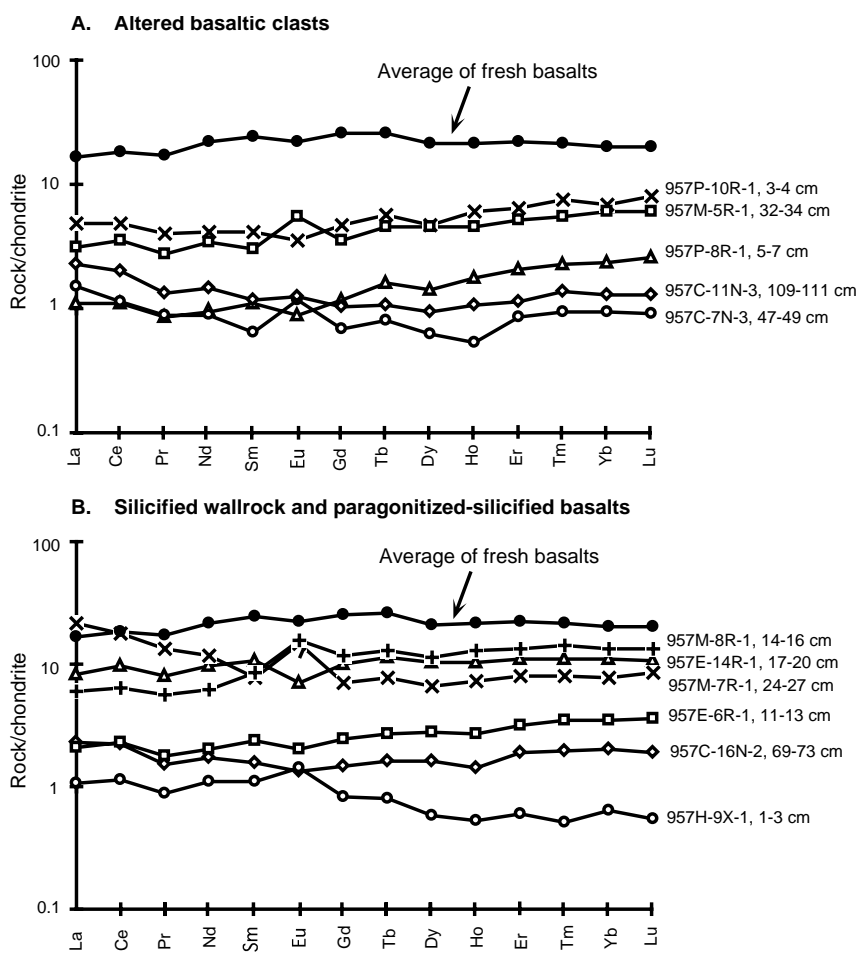

Figure 4. Chondrite-normalized REE data for samples of (A) altered basaltic clasts from within the mound and (B) silicified wallrock and paragonitizedsilicified basalt breccias from the underlying stockwork. The average REE composition for all the fresh basalts and basalt interiors is included on each plot for comparison. basis for comparison with the chloritized samples and alteration halos.

\section{Chloritized Samples from the TAG-1 Area}

Four samples from depths $>111 \mathrm{mbsf}$ in the stockwork zone at Hole 957E in the TAG-1 area have been analyzed and are denoted by the squares in Figure 5. One sample-Sample 158-957E-18R-1 (Piece 4, 20-24 cm) - comprises green chloritized rock surrounded by a paragonitized halo and includes a chlorite vein that is replaced by paragonite where the paragonite halo cuts across the chloritized basalt. The paragonite-rich halo (listed as "gray" in Tables 1, 2, and 3) was separated from the chloritized portion of the rock (listed as "green" in Tables 1, 2, and 3), and the two subsamples were analyzed separately. Only the chloritized portion of this sample is included in the following discussion. The chloritized samples are all altered to assemblages of chlorite (30-85 vol\%), quartz (10-45 vol\%), and pyrite (5-15 vol\%). The two chloritized samples with the lowest $\mathrm{H}_{2} \mathrm{O}^{+}$concentrations (Samples 158-957E-16R-1, Piece 3, 14-16 cm; and 158957E-18R-1, Piece 9, 45-47 cm) have the highest quartz and pyrite, respectively, as evidenced by the wide variation in their $\mathrm{SiO}_{2}$ contents (Fig. 5) and the high concentrations of $\mathrm{Fe}_{2} \mathrm{O}_{3}$ and $\mathrm{S}$ compared with the precursor basalts. All of the chloritized basalts exhibit lower $\mathrm{CaO}, \mathrm{Na}_{2} \mathrm{O}, \mathrm{K}_{2} \mathrm{O}$, and $\mathrm{TiO}_{2}$ contents, although at least part of this depletion may be a dilution effect. The $\mathrm{Al}_{2} \mathrm{O}_{3}$ and $\mathrm{MgO}$ contents vary from being lower to being almost the same as in the fresh basalt. In terms of trace elements, the concentrations of $\mathrm{Rb}, \mathrm{Sr}, \mathrm{V}, \mathrm{Ni}, \mathrm{Sc}, \mathrm{Zr}$, $\mathrm{Y}$, and $\mathrm{Nb}$ are all lower, whereas the Ba contents are essentially the
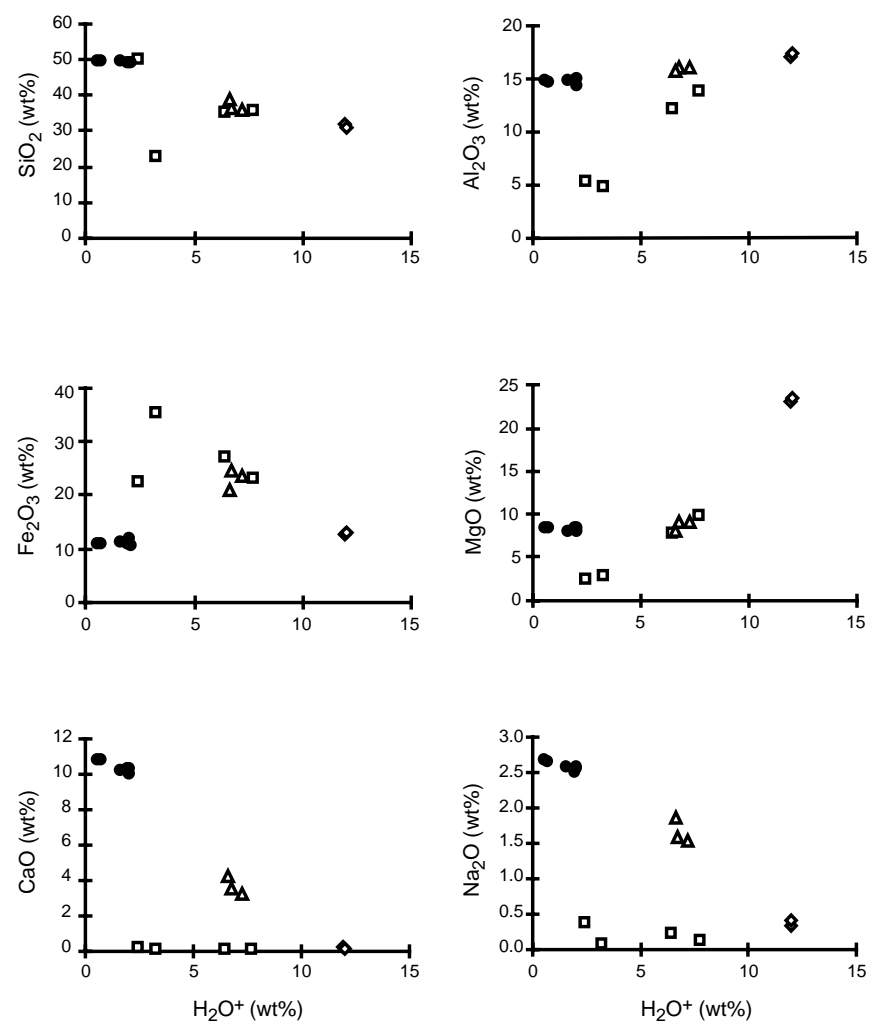

Figure 5. Variation in major element oxide concentrations plotted against $\mathrm{H}_{2} \mathrm{O}^{+}$contents as a measure of the extent of alteration for chloritized basalts from depths $>111$ mbsf in the stockwork zone from the TAG-1 area (open squares), hydrothermally altered pillow breccias from the TAG-2 area (open diamonds), and alteration halos on relatively fresh basalts from the TAG-4 area (open triangles). The solid circles represent analyses of relatively fresh basalts and basalt interiors from the TAG- 2 and TAG- 4 areas. 

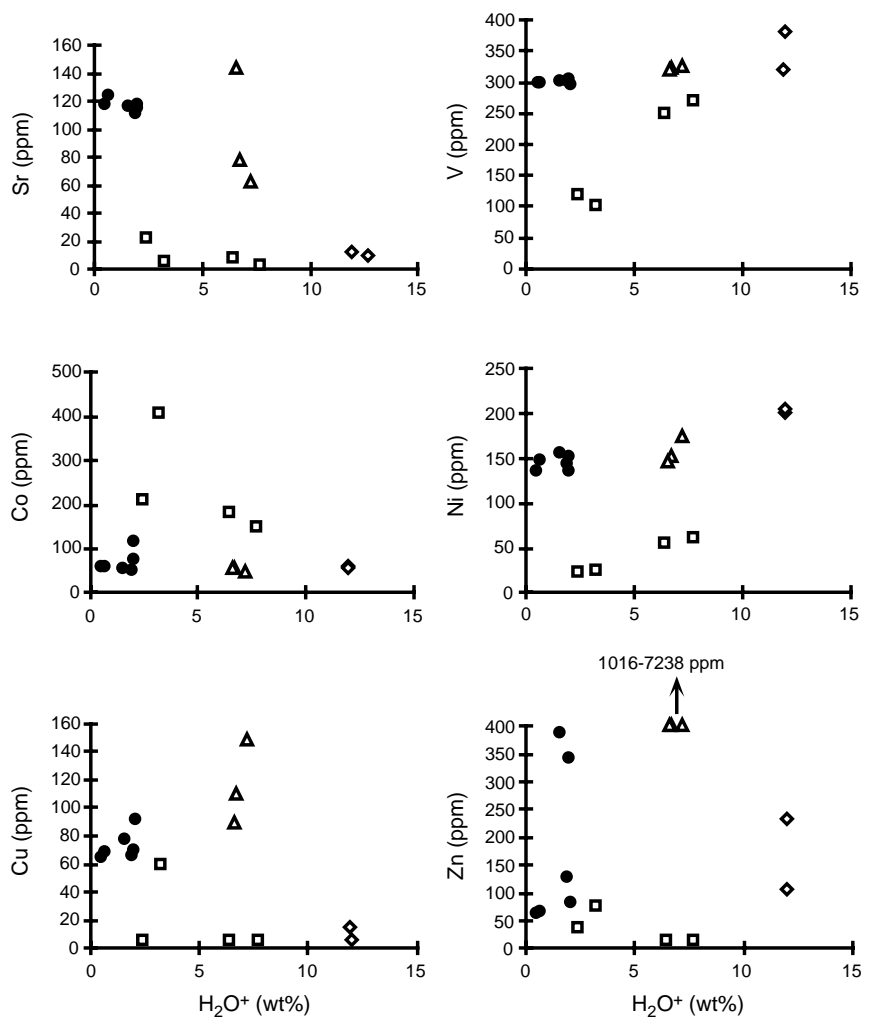

Figure 6. Covariation of selected trace element and $\mathrm{H}_{2} \mathrm{O}^{+}$concentrations for chloritized basalts. See Figure 5 caption for symbol designations.

same as in the fresh basalts. However, the depletions of $\mathrm{V}, \mathrm{Sc}, \mathrm{Zr}$, and $\mathrm{Y}$ are not as great as those seen in the paragonitized-silicified basalts. The contents of $\mathrm{Cu}$ and $\mathrm{Zn}$ are also considerably lower, except in Sample 158-957E-18R-1 (Piece 9, 45-47 cm), where the concentrations are similar to those in the precursor basalts and may reflect their presence in the sulfides that are abundant in this sample (Fig. 6). Co shows significantly higher concentrations in these samples, as is the case in the paragonitized-silicified basalts. The REE concentrations are all lower than in the fresh basalts (Table 3 ). This is particularly marked in the two samples dominated by quartz and pyrite. The most noticeable feature of the chondrite-normalized REE patterns (Fig. 7) is the development of a marked negative Eu anomaly. Because plagioclase exhibits a strong positive Eu anomaly and the REE patterns of the fresh mid-ocean ridge basalt (MORB) are flat, the development of a strong negative Eu anomaly in the altered rocks must reflect the release of Eu into the fluids during alteration of the plagioclase. This would further enhance the positive Eu anomaly seen in hydrothermal fluids attributed to reactions within the deep reaction zone (Klinkhammer et al., 1994).

\section{Hydrothermally Altered Pillow Breccias from the TAG-2 Area}

The clasts from the hydrothermally altered pillow breccia from Hole 957B in the TAG-2 area (two samples denoted by PR in Tables 1, 2, and 3, and the diamonds in Fig. 5) include blue-green chloritized glass (Sample 158-957B-4R-1, Piece 4, 39-41 cm) and reddish chloritized basalt (Sample 158-957B-4R-1, Piece 2, 17-24 cm). The altered glassy clasts are replaced by the most Mg-rich chlorite $(\mathrm{Fe} /(\mathrm{Fe}$ $+\mathrm{Mg})=0.17$ ) ever reported from seafloor basalt alteration (Honnorez et al., Chap. 18, this volume) and are cemented by chlorite, quartz, and hematite. Relative to the fresh basalt precursor, the major element compositions of these two samples show trends expected during chloritization (i.e., higher $\mathrm{H}_{2} \mathrm{O}^{+}$and $\mathrm{MgO}$, and lower $\mathrm{SiO}_{2}$ concentrations and almost complete loss of $\mathrm{CaO}$ and $\mathrm{Na}_{2} \mathrm{O}$ ). $\mathrm{Al}_{2} \mathrm{O}_{3}$, $\mathrm{Fe}_{2} \mathrm{O}_{3}$, and $\mathrm{TiO}_{2}$ exhibit only small changes in concentrations, being slightly higher than in the fresh precursor. The bulk-rock Sr-isotope ratios near seawater (Teagle et al., Chap. 22, this volume) indicate that the fluid with which these breccias reacted was dominated by seawater. The only large trace element variations relative to the altered and fresh samples are higher Ni concentrations (about $200 \mathrm{ppm}$ compared with about 30-150 ppm in the fresh samples) and almost complete removal of $\mathrm{Sr}(<115 \mathrm{ppm}$ compared with 111-124 ppm) and $\mathrm{Cu}(<15$ ppm compared with 64-92 ppm) (Fig. 6). The REE concentrations are slightly higher compared with the fresh basalt (Table 3) but, as indicated in Figure 7, the shape of the chondrite-normalized patterns does not change.

\section{Chlorite-Rich Halos from the TAG-4 Area}

The final group of chloritized samples are the three chlorite-rich halos (denoted by $\mathrm{AH}$ in Tables 1, 2, and 3) rimming fresher basalt interiors (denoted by BI) from the TAG- 4 area. The dark gray basalt interiors are 5\%-15\% altered, with smectites (saponite) and talc replacing olivine and interstitial areas and filling vesicles. The chloritized halos are about $1 \mathrm{~cm}$ in width and are 60\%-80\% altered, although some plagioclase microlites and $\mathrm{Fe}$-Ti oxides are still present. Chlorite and mixed layer chlorite-smectite replace olivine, pyroxene, and interstitial areas and fill vesicles (Honnorez et al., Chap. 18, this volume). The presence of red $\mathrm{Fe}$-oxide alteration halos that cut the chloritized halos suggests that chloritization was followed by lowtemperature alteration at this site. Figure 5 indicates that the major element concentrations of these samples (denoted by triangles) show trends similar to those of the pillow breccias, although the halos are not as highly altered. In general, the halos are intermediate in chemical composition between the fresh precursors and the more highly altered pillow breccias. The only notable difference is that the $\mathrm{Fe}_{2} \mathrm{O}_{3}$ concentrations are significantly higher $(20-25 \mathrm{wt} \%)$ than in either the fresh precursor or the pillow rim breccias, whereas the $\mathrm{MgO}$ content (7.88-9.01 wt\%) is little changed from the fresh precursor. In addition, two of the halos from Samples 158-957M-9R-1, 32-27 cm, and 158-957M-10R-1, 142-143 cm, contain measurable concentrations of $\mathrm{S}$ (0.48 and $0.58 \mathrm{wt} \%$, respectively), suggesting the presence of minor amounts of sulfides. The high $\mathrm{Fe}_{2} \mathrm{O}_{3}$ contents are caused by the presence of $\mathrm{Fe}$-rich chlorites $(\mathrm{Fe} /[\mathrm{Fe}+\mathrm{Mg}]$ up to 0.6$)$ rather than the Mg-rich chlorites observed at TAG-2 (Honnorez et al., Chap. 18, this volume). These differences in chlorite composition, together with the Sr-isotope ratios of the chloritized halos (Teagle et al., Chap. 22, this volume) suggest alteration by a hydrothermal fluid, rather than by a seawater-dominated fluid as at TAG-2.

In terms of trace elements, alteration halos show trends similar to those of the pillow breccias, except for the concentrations of $\mathrm{Cu}$ and $\mathrm{Zn}$, which are higher than in either the pillow breccias or the fresh interiors (Fig. 6). The $\mathrm{Cu}$ contents of the halos are quite variable and range from 89 to $148 \mathrm{ppm}$, compared with 66 to $77 \mathrm{ppm}$ in the interiors of the same samples. Pyrite and chalcopyrite have been identified in thin section in the halos as 5- to 100- $\mu \mathrm{m}$-diameter grains disseminated in interstitial areas and replacing groundmass and olivine (Humphris, Herzig, Miller, et al., 1996). The Zn contents are enriched by an order of magnitude over their concentrations in the precursors, ranging from 1016 to $7238 \mathrm{ppm}$ in the alteration halos, compared with 128 to $389 \mathrm{ppm}$ in the fresh interiors. In Sample 158-957M-9R$1,32-37 \mathrm{~cm}$, the concentration of $\mathrm{S}$ is sufficient to account for all of the $\mathrm{Zn}$ as sulfide; however, that is not the case in the other two samples. In addition, although sphalerite is present in the sulfides recovered from the TAG-4 area, none has been identified in thin sections from the altered basalts. Smith and Humphris (Chap. 17, this volume) have also carried out X-ray diffraction analyses on halos rich in $\mathrm{Zn}$, but have been unable to identify a Zn-rich phase. Comparison of the chondrite-normalized REE patterns of the alteration halos with their precursors (Fig. 7) indicates that, similar to the pillow breccias in the 


\section{A. Chloritized basalts from TAG-1}

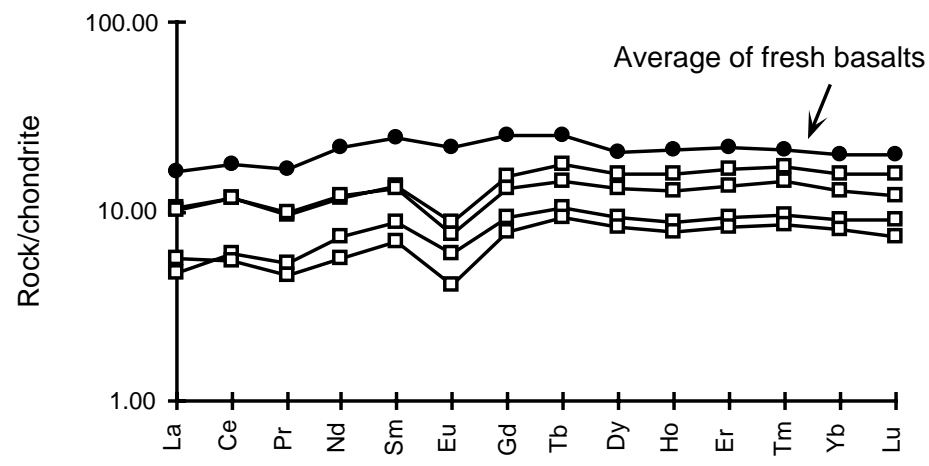

B. Pillow Breccias from TAG-2

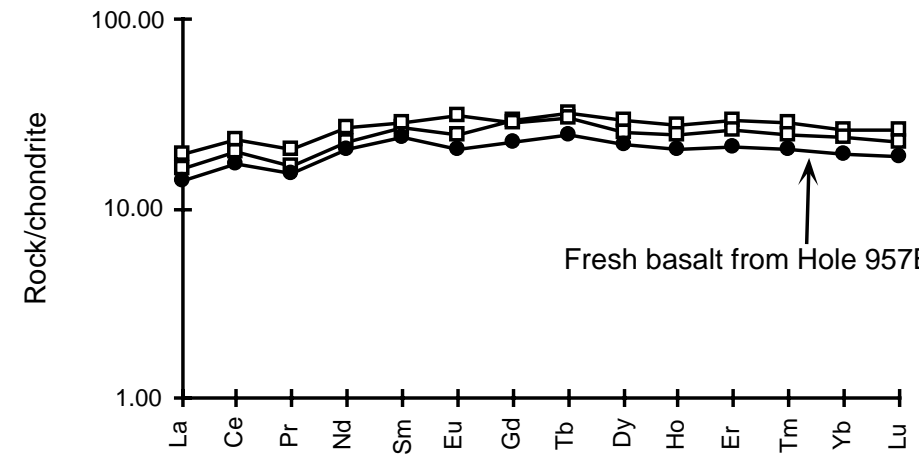

C. Alteration Halos from TAG-4

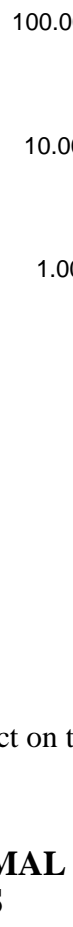

Table 4 shows average compositions for the two types of samples identified within the paragonitized-silicified basalts and clasts group, and the three types of samples within the chloritized basalts group compared with the average compositions for the fresh basalts. The compositions of the silicified wallrock and paragonitized-silicified basalt breccias from the upper part of the underlying stockwork and the altered basaltic clasts from within the mound are the same within the standard error, although the ranges in composition, particularly for $\mathrm{SiO}_{2}, \mathrm{Fe}_{2} \mathrm{O}_{3}$, and $\mathrm{S}$, are quite large as indicated by their standard deviations. Hence, in the following discussions, we consider all these samples as one group of paragonitized-silicified basalts. In contrast, the chloritized samples appear to form three distinct groups within the limits of the small number of samples within each group. The compositional variations between these groups reflect different physical and/or chemical conditions of alteration for those samples from the upflow zone (the TAG-1 samples) compared with those from the outer edges of the mound (the TAG-2 and TAG-4 samples).

Studies of the mineralogy of the hydrothermally altered basalts and basaltic clasts recovered from the sulfide mound and underlying stockwork at TAG have resulted in the development of a paragenesis of alteration (Humphris, Herzig, Miller, et al., 1996; Honnorez et al., Chap. 18, this volume). Early water-rock reactions resulted in the first stage of alteration of the basalt to a chlorite \pm quartz \pm pyrite as- 
Table 4. Comparison of average compositions of paragonitized-silicified and chloritized basalts with fresh precursors.

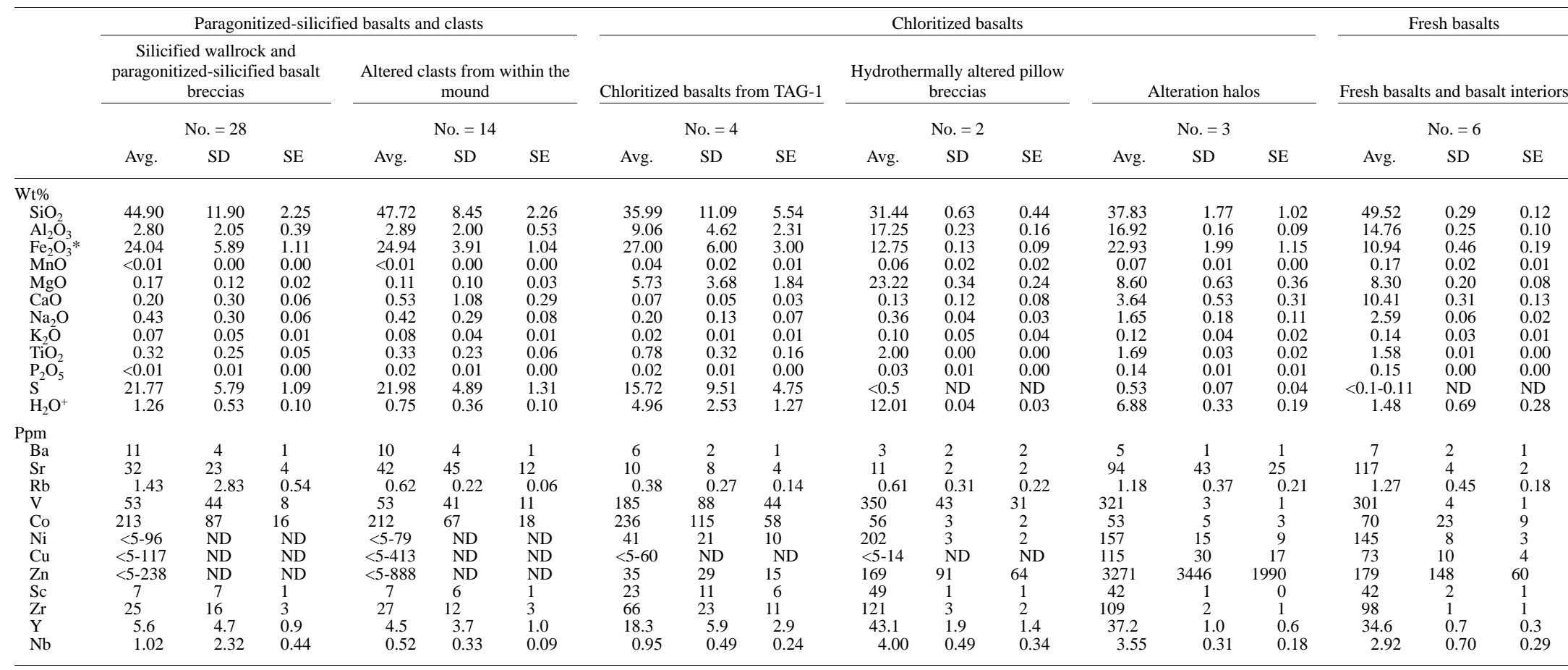

Notes: Avg. $=$ average; $\mathrm{SD}=$ standard deviation; $\mathrm{SE}=$ standard error; $\mathrm{No} .=$ number of samples; $\mathrm{ND}=$ not determined. $\mathrm{Fe}_{2} \mathrm{O}_{3}{ }^{*}=$ total iron as $\mathrm{Fe}_{2} \mathrm{O}_{3}$ 
semblage. Based on oxygen-isotope data, these reactions occurred at temperatures of about $300^{\circ} \mathrm{C}$ and at water-rock ratios of about 300 (Alt and Teagle, Chap. 21, this volume). During a second stage, this assemblage was replaced by paragonite \pm quartz \pm pyrite during reactions with hydrothermal fluids depleted in $\mathrm{Mg}$ but enriched in alkalis. The black smoker hydrothermal fluids at TAG are distinctive in their high $\mathrm{Na} / \mathrm{K}$ value of 34 , compared with those from other seafloor hydrothermal systems (e.g., 21 at Snakepit; 15-18 at S. Cleft on the Juan de Fuca Ridge; 13-26 at the Galapagos Spreading Center vents; Von Damm, 1995). This may account for the formation of paragonite at TAG rather than a more potassic mica. The final stage involved further silicification of the paragonite-rich assemblages. In addition to this sequence of water-rock reactions, entrainment and heating of seawater beneath the mound resulted in recent precipitation of anhydrite in veins. The chloritization of both the pillow clasts at TAG-2 and the alteration halos on basalts from TAG-4 attest to reactions between seawater and rocks at high temperatures (about $300^{\circ} \mathrm{C}$; Alt and Teagle, Chap. 21, this volume) extending in the subsurface at least to the periphery of the mound, although at both sites, there is also evidence for overprinting by later low-temperature alteration.

The sequence of alteration observed in basalts beneath the active TAG hydrothermal mound is similar to that described in some other modern seafloor hydrothermal deposits. Within the exposed stockwork underlying sulfide mounds of the extinct hydrothermal system on the Galapagos Ridge, the alteration assemblage is dominated by smectite, silica, pyrite, and chlorite (Embley et al., 1988). Rock-water reactions have resulted in strong depletion in $\mathrm{Ca}, \mathrm{Na}, \mathrm{K}$, and $\mathrm{Mn}$, enrichment in $\mathrm{S}$ and $\mathrm{Fe}$, and variable $\mathrm{Si}$ and $\mathrm{Mg}$ concentrations. At the Sea Cliff hydrothermal field on the northern Gorda Ridge where mineralization is developed in fault talus, Zierenberg et al. (1995) have documented an alteration sequence of $\mathrm{Mg}$-metasomatism at temperatures of $220^{\circ} \mathrm{C}$ converting the rock to smectites and smectite/chlorite, followed by silicification of the basalt and cementation by amorphous silica at temperatures below $100^{\circ} \mathrm{C}$. Geochemically, these alteration reactions resulted in near total silicification of the basaltic fragments with removal of almost all cations.

Alteration zones beneath some ancient, volcanic-hosted, massive sulfide deposits preserved in ophiolites also show similar alteration sequences, with chloritization of basalts preceding the development of mineral assemblages of quartz-chlorite-sericite, followed by complete replacement by quartz and sulfide. Although there are some mineral compositional differences, the basic mineralogical and chemical changes in alteration zones of deposits in Cyprus (e.g. the Mathiati deposit) and in Oman (e.g. the Bayda deposit) are similar, having undergone loss of alkalis, precipitation of large quantities of silica, and the formation of chlorite (Collinson, 1986; Lydon and Galley, 1986; Richards et al., 1989). Of particular note is the similarity between the vertical zonation of alteration mineral assemblages observed in the Turner-Albright deposit in the Josephine ophiolite (Zierenberg et al., 1988) and that seen at TAG (Humphris et al., 1995; Humphris, Herzig, Miller, et al., 1996). As in the case of the modern seafloor hydrothermal systems, the basalt alteration and silicification within this ophiolite-based massive sulfide deposit results in the removal of all cations, including $\mathrm{Al}$ and $\mathrm{Ti}$. Hence, subsurface waterrock reactions associated with hydrothermal circulation provide an important mechanism for exchange of elements between basement and circulating fluids.

\section{ELEMENTAL CHANGES ASSOCIATED WITH DIFFERENT TYPES OF ALTERATION}

In considering such intensely altered rocks as those described in this paper, establishing a way of normalizing the data so that relative elemental gains and losses can be determined is complex. The assumption of constant volume is one method that has been widely applied, but, given the brecciated nature of the samples, is not appropri- ate in this case. In addition, the selection of an element to consider as "immobile," and hence constant in concentration, is not obvious when the chemical compositions of the altered rocks are so different from their fresh precursors. One widely used method has been that of Gresens (1967) who argued that, if those components that are likely to have been immobile during alteration can be identified, they can be used to establish any volume change that has taken place, thereby allowing gains or losses of other components to be calculated based on that assumed volume change. Consequently, he considered composition-volume relations during alteration, and derived equations for calculation of gains and losses from chemical analyses and specific gravities of altered and unaltered rocks. His equation was later modified by Grant (1986) to one relating the concentration of a component in the altered rock to that in the original through a mass change term such that

$$
C_{i}^{A}=M^{o} / M^{A}\left(C_{i}^{o}+\Delta C_{i}\right)
$$

where $C_{i}^{A}=$ concentration of component $i$ in the altered rock; $M^{O}=$ mass of the original, fresh rock; $M^{A}=$ mass of the altered rock; $C_{i}^{O}=$ concentration of component $i$ in the original rock; and $\Delta C_{i}=$ change in concentration of component $i$.

Hence, if the analytical data are plotted as $C_{i}^{A}$ vs. $C_{i}^{o}$, those elements that are immobile (i.e., $\Delta C_{i}=0$ ) will define a mass change term $\left(M^{o} / M^{A}\right)$ or "isocon" that can be used to calculate gains and losses of other components through a series of simple equations. Since "relative immobility" can be the result of either no mass transfer of an element or geochemically similar behavior of certain elements during alteration, it is preferable to base determination of the isocon on as many geochemically dissimilar species as possible (Grant, 1986).

In this method, analyses have to be arbitrarily scaled to fit on a single plot of concentrations of elements in altered rock vs. their concentration in the fresh precursor. Depending on the scaling factor used, this results in points getting closer to or farther from a best-fit line through the "immobile" elements, depending on their distance from the origin. In the following analysis, we have modified the graphical representation of Grant's procedures to provide better visualization of relative immobility of elements. We have chosen to remove the visual effects of arbitrary scaling by scaling all the data to be the same distance from the origin (i.e., normalizing so that the sums of squares $=1$ ). This results in all of the data points lying along an arc of a circle centered on the origin. By evaluating which points group together (and hence are behaving similarly) and combining this with consideration of their geochemistry, we can evaluate which elements to use for calculation of the mass change term $\left(M^{O} / M^{A}\right)$, which can then be used to calculate elemental gains and losses.

For the calculations of elemental gains and losses during alteration, it is necessary to identify a precursor. For the chloritization of halos at TAG-4, the relatively fresh interiors of the samples provide a direct comparison. At TAG-2, an analysis of a sample of relatively fresh basalt underlying the pillow rim breccias was used as representative of the fresh precursor. For the chloritized basalts from TAG-1 and the paragonitized-silicified basalts and clasts, the selection of a precursor is more complex. The established sequence of alteration indicates that the first water-rock reactions resulted in chloritization, and hence a "fresh" basalt precursor is required. Rather than take the average value from Table 4, which includes some samples that show evidence of initial stages of low-temperature weathering (as indicated by the high average $\mathrm{H}_{2} \mathrm{O}^{+}$content of $1.48 \mathrm{wt} \%$ ), we have selected Sample 158-957M-10R-1 (Piece 6, 33-36 cm) as the fresh precursor based on its chemistry and its fresh basaltic Sr-isotope ratios (Teagle et al., Chap. 22, this volume). Paragonitization and silicification occurred post-chloritization; consequently, to trace the history of elemental gains and losses during each step of the alteration sequence, a chloritized precursor has been selected-this will be discussed in a later section. 


\section{A. Pillow breccia}

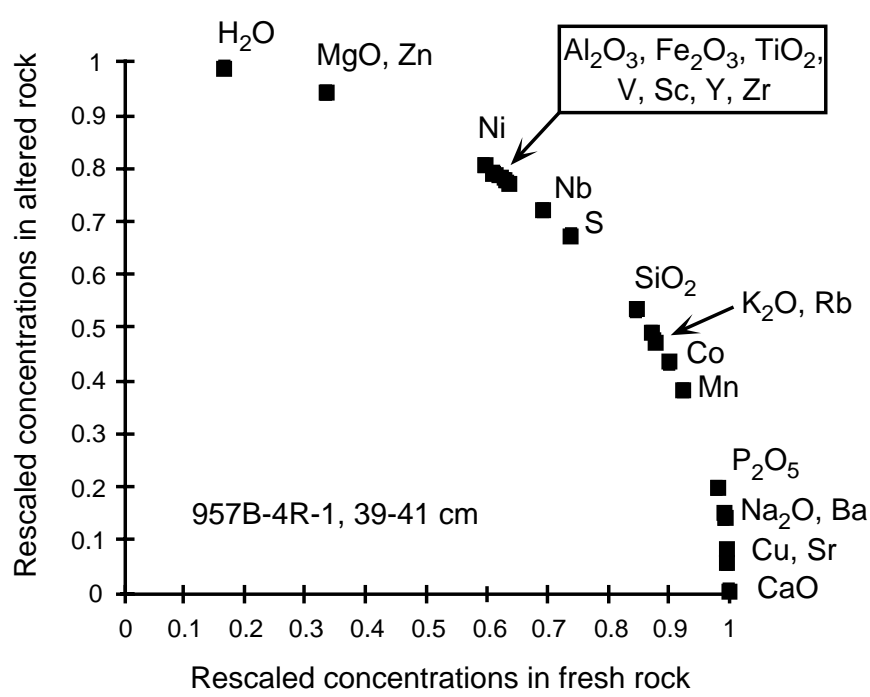

B. Alteration halo

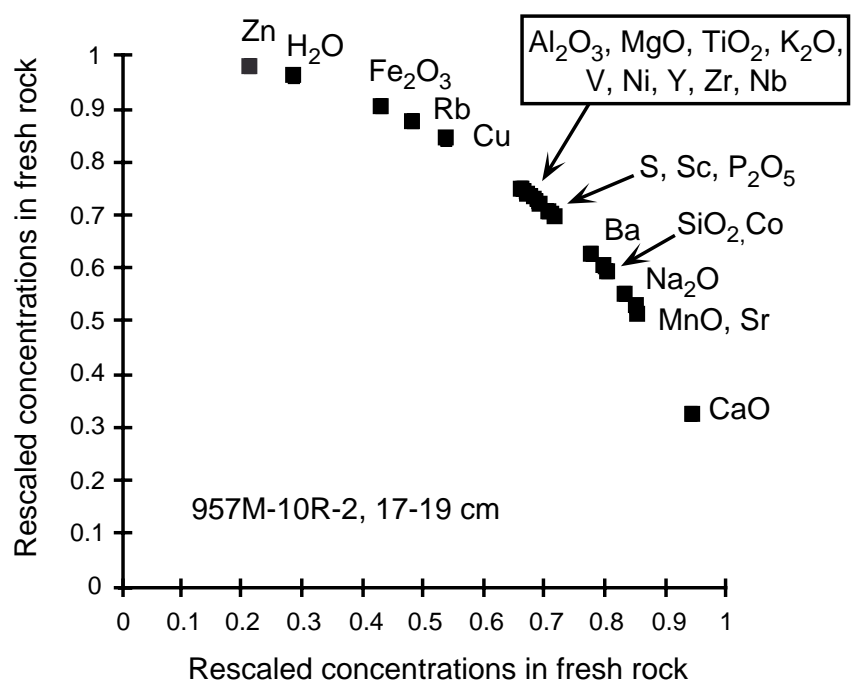

Figure 8. Examples of plots of the concentration data for (A) a pillow rimfresh precursor pair and (B) a halo-interior pair rescaled to allow evaluation of which elements may be considered "relatively immobile" during the alteration process. The concentration data have been standardized so that the sums of squares equals 1, thereby resulting in all data points lying along the arc of a unit circle (see text for further discussion).

In the following discussion, we will first consider the alteration of the pillow breccias and halos not only because precursors for these samples are available, but also because they provide the simplest example of the application of our method for examining elemental exchange. We will then consider separately the fluxes associated with chloritization of fresh basalt within the stockwork, followed by paragonitization and silicification.

\section{Alteration of Pillow Breccias (at TAG-2) and Halos (at TAG-4)}

Sr-isotope data (Teagle et al., Chap. 22, this volume) indicates that alteration by a seawater-rich fluid took place at TAG-2, resulting in Mg-rich chloritization of the pillow breccias. In contrast, in the TAG-4 area, we have presented evidence that the alteration rims on the fresh basalts at TAG-4 suggest reactions with hydrothermal fluids. These differences probably result from the complex fluid flow and mixing regimes within the mound and the underlying stockwork.

To select the elements to use for determination of the isocon, we have examined each sample individually, with the alteration halos being compared with their fresh interiors, and the pillow breccias being compared with a single sample of a relatively fresh basalt immediately beneath the altered material. Examples of plots of the rescaled concentration data for a halo-interior pair and for a pillow rim-fresh precursor pair are shown in Figure 8. These illustrate that there are some distinct differences in gains/losses of individual elements between the two sample types. On each diagram (and on those for the other samples not included here), there is a distinct grouping of a suite of elements with similar arc lengths. Examination of this group of elements and comparison among all of the samples indicates that there are four components that consistently group together: $\mathrm{TiO}_{2}$, $\mathrm{Al}_{2} \mathrm{O}_{3}, \mathrm{Zr}$, and $\mathrm{Y}$ (and also the REE although they are not included in Figure 8). We have selected two major oxide components within this group - $\mathrm{TiO}_{2}$ and $\mathrm{Al}_{2} \mathrm{O}_{3}$ - to calculate the mass change term, (i.e., the slope of the line through the average of these points to the origin), although it should be emphasized that use of the entire group to calculate the mass change term results in only minor changes to the calculated elemental changes.

Table 5 shows the results of the calculations of gains and losses of elements during chloritization of halos and pillow breccias. Note that the mass change term (Grant, 1986) indicates that there is a decrease in mass during alteration, with only a slight decrease in the alteration halos (about 5\%-7\%) and a greater decrease in the pillow breccias (about 22\%-24\%). In both cases, significant amounts of $\mathrm{SiO}_{2}$ and $\mathrm{CaO}$, and lesser amounts of $\mathrm{Na}_{2} \mathrm{O}$, have been lost, whereas $\mathrm{H}_{2} \mathrm{O}^{+}$and either $\mathrm{Fe}_{2} \mathrm{O}_{3}$ (in the case of the halos) or $\mathrm{MgO}$ (in the case of the pillow breccias) have been gained. The difference in the behavior of $\mathrm{Fe}_{2} \mathrm{O}_{3}$ and $\mathrm{MgO}$ reflects the compositions of the chlorite forming at each site. In terms of trace elements, Co is generally lost and $\mathrm{Zn}$ is gained, but $\mathrm{V}, \mathrm{Ni}$, and $\mathrm{Cu}$ show variable trends. No major changes in the concentrations of the REE result from these types of alteration.

\section{Chloritization of the Basalts in the Stockwork (at TAG-1)}

Of the four chloritized samples from greater than $111 \mathrm{mbsf}$ that were analyzed, we have selected two for calculation of the elemental gains and losses: Samples 158-957E-18R-1 (Piece 1, 4-7 cm) and the chloritized portion of Sample 158-957E-18R-1 (Piece 4, 20-24 cm). Both of these samples are composed of about 80-85 vol\% chlorite with $10-15$ vol\% quartz and about 5 vol\% pyrite. The other two samples were excluded on the basis of their mineralogy and the presence of extensive veining, suggesting that they have been affected by later alteration processes. Sample 158-957E-16R-1 (Piece 3, 14-16 cm) consists of only about $30 \mathrm{vol} \%$ chlorite, but has about $10 \mathrm{vol} \%$ paragonite and an extensive fine network of quartz veins. Sample 158957E-18R-1 (Piece 9, 45-47 cm) contains paragonite and includes pyrite and quartz veins that are visually estimated to comprise about $20 \mathrm{vol} \%$.

Table 6 shows the results of calculation of the gains and losses of components during chloritization when compared with the selected fresh precursor (Sample 158-957M-10R-1, Piece 6, 33-36 cm). For this type of alteration, the elements that grouped together and hence were assumed to be relatively immobile included $\mathrm{TiO}_{2}, \mathrm{Y}$, and the heavy REE (defined here as Dy to $\mathrm{Lu}$ ). The mass change term indicates that these samples have increased in mass during alteration by $25 \%-30 \%$, likely resulting from the addition of significant quantities of $\mathrm{Fe}$ and $\mathrm{S}$ in the form of pyrite, whereas the $\mathrm{SiO}_{2}$ content has been maintained or shows a slight increase because of replacement by quartz. Essentially all of the $\mathrm{CaO}, \mathrm{Na}_{2} \mathrm{O}, \mathrm{Sr}$, and $\mathrm{Rb}$ are lost presumably because of alteration of plagioclase. Small amounts of $\mathrm{Al}_{2} \mathrm{O}_{3}$ and 
Table 5. Gains and losses from alteration of halos (at TAG-4) and pillow breccias (at TAG-2).

\begin{tabular}{|c|c|c|c|c|c|}
\hline & \multicolumn{3}{|c|}{ Alteration halos } & \multicolumn{2}{|c|}{ Pillow breccias } \\
\hline & $\begin{array}{c}158-957 \mathrm{M}-9 \mathrm{R}-1 \\
32-37 \mathrm{~cm} \\
\text { Piece } 6\end{array}$ & $\begin{array}{c}158-957 \mathrm{M}-10 \mathrm{R} \\
142-143 \mathrm{~cm} \\
\text { Piece } 21\end{array}$ & $\begin{array}{c}\text { 158-957M-10R-2 } \\
17-19 \mathrm{~cm} \\
\text { Piece } 3\end{array}$ & $\begin{array}{c}158-957 \mathrm{~B}-4 \mathrm{R}-1 \\
17-24 \mathrm{~cm} \\
\text { Piece } 2\end{array}$ & $\begin{array}{c}\text { 158-957B-4R-1 } \\
39-41 \mathrm{~cm} \\
\text { Piece } 4\end{array}$ \\
\hline $\begin{array}{l}\mathrm{SiO}_{2} \\
\mathrm{Al}_{2} \mathrm{O}_{3} \\
\mathrm{Fe}_{2} \mathrm{O}_{3} * \\
\mathrm{MnO} \\
\mathrm{MgO} \\
\mathrm{CaO} \\
\mathrm{Na}_{2} \mathrm{O} \\
\mathrm{K}_{2} \mathrm{O} \\
\mathrm{TiO}_{2} \\
\mathrm{P}_{2} \mathrm{O}_{5}\end{array}$ & $\begin{array}{r}-16.30 \\
0.12 \\
10.94 \\
-0.10 \\
-0.12 \\
-7.35 \\
-1.10 \\
-0.04 \\
-0.01 \\
-0.01\end{array}$ & $\begin{array}{r}-12.84 \\
0.05 \\
8.60 \\
-0.10 \\
-0.58 \\
-6.22 \\
-0.81 \\
0.02 \\
0.00 \\
-0.03\end{array}$ & $\begin{array}{r}-15.48 \\
-0.13 \\
11.24 \\
-0.06 \\
0.33 \\
-6.80 \\
-1.12 \\
0.00 \\
0.01 \\
-0.01\end{array}$ & $\begin{array}{r}-23.27 \\
-0.43 \\
-0.22 \\
-0.14 \\
10.32 \\
-10.12 \\
-2.28 \\
0.00 \\
0.05 \\
-0.13\end{array}$ & $\begin{array}{r}-24.23 \\
-0.31 \\
-0.16 \\
-0.11 \\
10.53 \\
-10.26 \\
-2.24 \\
-0.06 \\
0.03 \\
-0.13\end{array}$ \\
\hline $\begin{array}{l}\mathrm{H}_{2} \mathrm{O}^{+} \\
\mathrm{S}\end{array}$ & $\begin{array}{l}4.79 \\
0.35\end{array}$ & $\begin{array}{l}4.72 \\
0.45\end{array}$ & $\begin{array}{r}4.30 \\
-0.01\end{array}$ & $\begin{array}{r}7.69 \\
-0.03\end{array}$ & $\begin{array}{r}7.64 \\
-0.03\end{array}$ \\
\hline $\begin{array}{l}\mathrm{Ba} \\
\mathrm{Sr} \\
\mathrm{Rb}\end{array}$ & $\begin{array}{c}1 \\
-54 \\
-0.27\end{array}$ & $\begin{array}{l}-2 \\
20 \\
-0.53\end{array}$ & $\begin{array}{l}-1 \\
-45 \\
0.58\end{array}$ & $\begin{array}{c}-4 \\
-106 \\
-0.02\end{array}$ & $\begin{array}{c}-6 \\
-109 \\
-0.39\end{array}$ \\
\hline $\begin{array}{l}\mathrm{V} \\
\mathrm{Co} \\
\mathrm{Ni} \\
\mathrm{Cu} \\
\mathrm{Zn}\end{array}$ & $\begin{array}{r}-1 \\
-8 \\
17 \\
71 \\
815\end{array}$ & $\begin{array}{r}1 \\
-4 \\
-18 \\
7 \\
6478\end{array}$ & $\begin{array}{r}-5 \\
-22 \\
7 \\
32 \\
1117\end{array}$ & $\begin{array}{r}-35 \\
-67 \\
11 \\
-81 \\
2\end{array}$ & $\begin{array}{r}11 \\
-70 \\
12 \\
-88 \\
105\end{array}$ \\
\hline $\begin{array}{l}\mathrm{Sc} \\
\mathrm{Zr} \\
\mathrm{Y} \\
\mathrm{Nb}\end{array}$ & $\begin{array}{l}-3 \\
4 \\
-0.3 \\
0.17\end{array}$ & $\begin{array}{l}-1 \\
2 \\
0.1 \\
0.29\end{array}$ & $\begin{array}{l}-4 \\
4 \\
1.3 \\
0.15\end{array}$ & $\begin{array}{l}1 \\
4 \\
2.1 \\
0.01\end{array}$ & $\begin{array}{l}0 \\
0 \\
-0.4 \\
-0.58\end{array}$ \\
\hline $\begin{array}{l}\mathrm{La} \\
\mathrm{Ce} \\
\mathrm{Pr} \\
\mathrm{Nd} \\
\mathrm{Sm} \\
\mathrm{Eu} \\
\mathrm{Gd} \\
\mathrm{Tb} \\
\mathrm{Dy} \\
\mathrm{Ho} \\
\mathrm{Er} \\
\mathrm{Tm} \\
\mathrm{Yb} \\
\mathrm{Lu} \\
\mathrm{Hf}\end{array}$ & $\begin{array}{r}0.22 \\
-0.05 \\
0.04 \\
-0.33 \\
-0.02 \\
0.04 \\
-0.12 \\
-0.03 \\
-0.07 \\
-0.01 \\
-0.15 \\
0.02 \\
0.25 \\
0.02 \\
0.13\end{array}$ & $\begin{array}{l}0.43 \\
1.12 \\
0.19 \\
1.27 \\
0.16 \\
0.13 \\
0.22 \\
0.05 \\
0.08 \\
0.04 \\
0.13 \\
0.01 \\
0.14 \\
0.03 \\
0.47\end{array}$ & $\begin{array}{l}0.46 \\
1.01 \\
0.11 \\
0.72 \\
0.06 \\
0.02 \\
0.10 \\
0.07 \\
0.30 \\
0.07 \\
0.06 \\
0.02 \\
0.07 \\
0.02 \\
0.29\end{array}$ & $\begin{array}{r}-0.18 \\
-0.76 \\
-0.16 \\
-1.04 \\
-0.30 \\
-0.04 \\
0.18 \\
0.05 \\
0.54 \\
0.10 \\
0.42 \\
0.07 \\
0.32 \\
0.05 \\
-1.15\end{array}$ & $\begin{array}{r}0.33 \\
1.00 \\
0.13 \\
0.49 \\
-0.13 \\
0.24 \\
0.01 \\
-0.02 \\
-0.22 \\
-0.05 \\
-0.03 \\
-0.02 \\
-0.05 \\
-0.02 \\
-0.81\end{array}$ \\
\hline Mass change term & 1.07755 & 1.05402 & 1.06711 & 1.22902 & 1.24070 \\
\hline
\end{tabular}

Notes: Major elements are given in weight percent; trace and rare earth elements are given in parts per million. Alteration halos are compared to their fresh interiors; the pillow breccias are compared to Sample 957B-4R-1 (Piece 8, 55-62 cm). $\mathrm{Fe}_{2} \mathrm{O}_{3} *=$ total iron as $\mathrm{Fe}_{2} \mathrm{O}_{3}$.

$\mathrm{MgO}$ are gained during formation of chlorite, which may also account for some of the observed increase in $\mathrm{Fe}_{2} \mathrm{O}_{3}$. Ni, $\mathrm{Cu}$, and $\mathrm{Zn}$ are lost, and Co (presumably in pyrite) and $\mathrm{V}$ are added. The uptake of $\mathrm{Mg}$ and $\mathrm{Fe}$ to form chlorite, as well as $\mathrm{Fe}$ and $\mathrm{S}$ during the formation of pyrite, indicates that the initial fluids that reacted with basement beneath the mound were a mixture of hydrothermal fluid and seawater. Low bulk-rock Sr-isotope ratios indicate that end-member hydrothermal fluid was the dominant component (Teagle et al., Chap. 22, this volume).

\section{Paragonitization and Silicification of the Chloritized Basalts}

Chloritization of basalts within the stockwork was followed by replacement by paragonite \pm quartz \pm pyrite and subsequent further silicification. Consequently, this group of samples is extremely heterogeneous and shows a wide range in modal and chemical composition, depending on the extent to which the alteration and replacement reactions have proceeded. To represent the gains and losses of components associated with these reactions, we have selected three samples that span the range of observed mineralogical and chemical compositions, taking care to avoid any samples that exhibit fine networks of veins.

The selection of one of the two chloritized samples from Table 6 as the precursor for comparison with the paragonitized-silicified samples is somewhat arbitrary. The major distinction between them is that Sample 158-957E-18R-1 (Piece 4, 20-24 cm) has gained more $\mathrm{Fe}$ and $\mathrm{S}$, reflecting the presence of more pyrite in this sample. It should also be noted that this sample is the one previously described that consists of green chloritized rock surrounded by a paragonitized halo. Although it could be argued that this therefore provides a direct precursor for the paragonitization of the chloritized interior portion of the sample, it is not clear whether formation of all the pyrite is associated with the first step of alteration (i.e., chloritization) or includes some pyrite that formed during the later stages, and hence it may not be the most appropriate precursor for other samples. We have therefore selected Sample 158-957E-18R-1 (Piece 1, 4-7 cm) as the precursor for paragonitization and silicification, although we have included a calculation of gains and losses from Sample 158-957E-18R1 (Piece 4, 20-24 cm) from its own precursor as a comparison.

Table 7 shows the results of calculations of the gains and losses of elements resulting from paragonitization and increasing degrees of silicification. Sample 957E-14R-1 (Piece 5, 17-20 cm) is an example of one of the more highly paragonitized samples, with modal estimates of $70 \mathrm{vol} \%$ paragonite, $15 \mathrm{vol} \%$ quartz, and $15 \mathrm{vol} \%$ pyrite. The other two samples show decreasing abundance of paragonite and increasing replacement by quartz, with modal proportions being approximately $35 \mathrm{vol} \%$ paragonite, $50 \mathrm{vol} \%$ quartz, and $15 \mathrm{vol} \%$ pyrite in Sample 158-957M-5R-1 (Piece 7, 32-34 cm), and 25 vol\% paragonite, 65 vol\% quartz, and 10 vol\% pyrite in Sample 158-957E18R-1 (Piece 4, 20-24 cm). As samples become increasingly replaced and silicified, the assumption that a group of relatively immo- 
Table 6. Gains and losses from chloritization of basalts at TAG-1 based on comparison with Sample 158-957M-10R-1 (Piece 6, 33-36 cm).

\begin{tabular}{|c|c|c|}
\hline & $\begin{array}{c}\text { 158-957E-18R-1 } \\
4-7 \mathrm{~cm} \\
\text { Piece } 1\end{array}$ & $\begin{array}{l}\text { 158-957E-18R-1 } \\
\text { 20-24 cm } \\
\text { Piece } 4\end{array}$ \\
\hline $\begin{array}{l}\mathrm{SiO}_{2} \\
\mathrm{Al}_{2} \mathrm{O}_{3} \\
\mathrm{Fe}_{2} \mathrm{O}_{3} * \\
\mathrm{MnO} \\
\mathrm{MgO} \\
\mathrm{CaO} \\
\mathrm{Na}_{2} \mathrm{O} \\
\mathrm{K}_{2} \mathrm{O} \\
\mathrm{TiO}_{2} \\
\mathrm{P}_{2} \mathrm{O}_{5}\end{array}$ & $\begin{array}{r}-1.91 \\
3.75 \\
20.16 \\
-0.10 \\
4.67 \\
-10.73 \\
-2.49 \\
-0.16 \\
-0.06 \\
-0.14\end{array}$ & $\begin{array}{r}7.33 \\
5.21 \\
33.43 \\
-0.10 \\
4.36 \\
-10.70 \\
-2.27 \\
-0.12 \\
-0.04 \\
-0.13\end{array}$ \\
\hline $\begin{array}{l}\mathrm{H}_{2} \mathrm{O}^{+} \\
\mathrm{S}\end{array}$ & $\begin{array}{l}9.63 \\
9.83\end{array}$ & $\begin{array}{r}9.81 \\
16.92\end{array}$ \\
\hline $\begin{array}{l}\mathrm{Ba} \\
\mathrm{Sr} \\
\mathrm{Rb}\end{array}$ & $\begin{array}{l}-5 \\
-120 \\
-1.56\end{array}$ & $\begin{array}{c}1 \\
-112 \\
-1.47\end{array}$ \\
\hline $\begin{array}{l}\text { V } \\
\mathrm{Co} \\
\mathrm{Ni} \\
\mathrm{Cu} \\
\mathrm{Zn}\end{array}$ & $\begin{array}{r}63 \\
140 \\
-65 \\
-62 \\
-49\end{array}$ & $\begin{array}{l}109 \\
234 \\
-58 \\
-61 \\
-43\end{array}$ \\
\hline $\begin{array}{l}\mathrm{Sc} \\
\mathrm{Zr} \\
\mathrm{Y} \\
\mathrm{Nb}\end{array}$ & $\begin{array}{c}7 \\
-10 \\
-1.2 \\
-1.06\end{array}$ & $\begin{array}{l}9 \\
31 \\
-2.4 \\
-1.14\end{array}$ \\
\hline $\begin{array}{l}\mathrm{La} \\
\mathrm{Ce} \\
\mathrm{Pr} \\
\mathrm{Nd} \\
\mathrm{Sm} \\
\mathrm{Eu} \\
\mathrm{Gd} \\
\mathrm{Tb} \\
\mathrm{Dy} \\
\mathrm{Ho} \\
\mathrm{Er} \\
\mathrm{Tm} \\
\mathrm{Yb} \\
\mathrm{Lu} \\
\mathrm{Hf}\end{array}$ & $\begin{array}{r}-0.83 \\
-1.47 \\
-0.45 \\
-3.10 \\
-0.95 \\
-0.60 \\
-1.21 \\
-0.10 \\
0.07 \\
-0.04 \\
-0.01 \\
0.03 \\
0.01 \\
0.02 \\
0.02\end{array}$ & $\begin{array}{r}-0.23 \\
0.69 \\
-0.13 \\
-1.13 \\
-0.48 \\
-0.56 \\
-0.95 \\
-0.10 \\
0.24 \\
-0.03 \\
-0.03 \\
0.04 \\
0.07 \\
-0.01 \\
1.04\end{array}$ \\
\hline Mass change term & 0.74903 & 0.61340 \\
\hline
\end{tabular}

Note: Major elements are given in weight percent; trace and rare earth elements are given in parts per million. $\mathrm{Fe}_{2} \mathrm{O}_{3} *$ total iron as $\mathrm{Fe}_{2} \mathrm{O}_{3}$.

bile elements can be used to determine the mass change begins to break down. This can be seen graphically in Figure 9 for the most silicified sample, where the rescaled major and trace components are scattered along the arc of the unit circle, indicative of mobility of most (if not all) of the elements. Consequently, to provide some comparison of fluxes between the highly silicified sample and those that are paragonitized, we have used $\mathrm{TiO}_{2}$ (which is common to the relatively immobile groups of elements determined for the other two samples) to calculate the mass change term. Hence, the calculated gains and losses are relative to $\mathrm{TiO}_{2}$, although it must be borne in mind that this element may also be mobile.

The gain and loss trends are quite distinct from those associated with chloritization. The paragonitized sample appears to have increased in mass by about $30 \%$, and additional mass is added as pyrite and silica replace the rock during silicification. Apart from the obvious increasing gains in $\mathrm{SiO}_{2}, \mathrm{Fe}_{2} \mathrm{O}_{3}$, and $\mathrm{S}$ as pyrite and silica form, there is essentially complete loss of $\mathrm{MgO}$ and $\mathrm{H}_{2} \mathrm{O}^{+}$and addition of $\mathrm{Na}_{2} \mathrm{O}$ as chlorite is altered to paragonite. $\mathrm{All} \mathrm{CaO}$ was lost during the previous chloritization phase of alteration. $\mathrm{Cu}$ had also previously been lost and shows little change during paragonitization, but for the most intensely silicified sample there is an addition of $\mathrm{Cu}$ that is most likely in association with the formation of pyrite. About the same amount of $\mathrm{Zn}$ that was lost during chloritization is added back during paragonitization.

Comparison of the two results for Sample 158-957E-18R-1 (Piece $4,20-24 \mathrm{~cm}$ ) illustrates the effects of the choice of chloritized precur-
Table 7. Gains and losses with increasing paragonitization and silicification of chloritized basalts.

\begin{tabular}{|c|c|c|c|c|}
\hline & $\begin{array}{c}\text { 158-957E-14R-1 } \\
17-20 \mathrm{~cm} \\
\text { Piece } 5^{*}\end{array}$ & $\begin{array}{c}\text { 158-957M-5R-1 } \\
32-34 \mathrm{~cm} \\
\text { Piece 7* }\end{array}$ & $\begin{array}{c}\text { 158-957E-18R-1 } \\
20-24 \mathrm{~cm} \\
\text { Piece } 4 \text { (gy)* }\end{array}$ & $\begin{array}{c}158-957 \mathrm{E}-18 \mathrm{R}-1 \\
20-24 \mathrm{~cm} \\
\text { Piece } 4(\mathrm{gy})^{* *}\end{array}$ \\
\hline $\begin{array}{l}\mathrm{SiO}_{2} \\
\mathrm{Al}_{2} \mathrm{O}_{3} \\
\mathrm{Fe}_{2} \mathrm{O}_{3} * \\
\mathrm{MnO} \\
\mathrm{MgO} \\
\mathrm{CaO} \\
\mathrm{Na}_{2} \mathrm{O} \\
\mathrm{K}_{2} \mathrm{O} \\
\mathrm{TiO}_{2} \\
\mathrm{P}_{2} \mathrm{O}_{5}\end{array}$ & $\begin{array}{r}20.36 \\
-4.39 \\
12.73 \\
-0.05 \\
-9.31 \\
0.08 \\
1.30 \\
0.26 \\
0.04 \\
0.00\end{array}$ & $\begin{array}{r}40.71 \\
-2.86 \\
25.33 \\
-0.04 \\
-9.64 \\
0.07 \\
1.56 \\
0.25 \\
0.03 \\
0.01\end{array}$ & $\begin{array}{r}77.19 \\
-1.60 \\
47.11 \\
-0.03 \\
-8.84 \\
0.55 \\
1.81 \\
0.30 \\
0.00 \\
0.02\end{array}$ & $\begin{array}{r}80.33 \\
-4.57 \\
16.88 \\
-0.03 \\
-7.24 \\
0.32 \\
0.97 \\
0.17 \\
-0.23 \\
0.01\end{array}$ \\
\hline $\begin{array}{l}\mathrm{H}_{2} \mathrm{O}^{+} \\
\mathrm{S}\end{array}$ & $\begin{array}{r}-5.63 \\
24.64\end{array}$ & $\begin{array}{r}-6.10 \\
36.05\end{array}$ & $\begin{array}{l}-3.80 \\
48.15\end{array}$ & $\begin{array}{r}-3.98 \\
24.35\end{array}$ \\
\hline $\begin{array}{l}\mathrm{Ba} \\
\mathrm{Sr} \\
\mathrm{Rb}\end{array}$ & $\begin{array}{c}28 \\
108 \\
0.93\end{array}$ & $\begin{array}{l}23 \\
66 \\
1.09\end{array}$ & $\begin{array}{r}33 \\
118 \\
5\end{array}$ & $\begin{array}{l}17 \\
68 \\
3.27\end{array}$ \\
\hline $\begin{array}{l}\mathrm{V} \\
\mathrm{Co} \\
\mathrm{Ni} \\
\mathrm{Cu} \\
\mathrm{Zn}\end{array}$ & $\begin{array}{r}-103 \\
405 \\
6 \\
2 \\
59\end{array}$ & $\begin{array}{r}-48 \\
136 \\
15 \\
4 \\
69\end{array}$ & $\begin{array}{r}-70 \\
741 \\
55 \\
99 \\
81\end{array}$ & $\begin{array}{r}-124 \\
377 \\
18 \\
60 \\
45\end{array}$ \\
\hline $\begin{array}{l}\mathrm{Sc} \\
\mathrm{Zr} \\
\mathrm{Y} \\
\mathrm{Nb}\end{array}$ & $\begin{array}{l}-10 \\
0 \\
-3.0 \\
-0.58\end{array}$ & $\begin{array}{l}-8 \\
-2 \\
-12.2 \\
-0.71\end{array}$ & $\begin{array}{c}7 \\
12 \\
-5.4 \\
0.53\end{array}$ & $\begin{array}{c}-4 \\
-30 \\
-7.6 \\
0.09\end{array}$ \\
\hline $\begin{array}{l}\mathrm{La} \\
\mathrm{Ce} \\
\mathrm{Pr} \\
\mathrm{Nd} \\
\mathrm{Sm} \\
\mathrm{Eu} \\
\mathrm{Gd} \\
\mathrm{Tb} \\
\mathrm{Dy} \\
\mathrm{Ho} \\
\mathrm{Er} \\
\mathrm{Tm} \\
\mathrm{Yb} \\
\mathrm{Lu} \\
\mathrm{Hf}\end{array}$ & $\begin{array}{r}0.27 \\
0.89 \\
0.16 \\
0.93 \\
0.13 \\
0.05 \\
-0.28 \\
-0.07 \\
-0.40 \\
-0.08 \\
-0.23 \\
-0.05 \\
-0.06 \\
-0.02 \\
-0.22\end{array}$ & $\begin{array}{r}-1.11 \\
-3.31 \\
-0.43 \\
-2.62 \\
-1.29 \\
0.07 \\
-1.81 \\
-0.35 \\
-1.96 \\
-0.42 \\
-1.25 \\
-0.18 \\
-0.80 \\
-0.12 \\
0.12\end{array}$ & $\begin{array}{r}-0.24 \\
-1.05 \\
-0.11 \\
-0.69 \\
-0.51 \\
0.03 \\
-0.69 \\
-0.14 \\
-0.81 \\
-0.17 \\
-0.46 \\
-0.08 \\
-0.35 \\
-0.05 \\
-0.86\end{array}$ & $\begin{array}{l}-1.00 \\
-3.40 \\
-0.44 \\
-2.70 \\
-1.02 \\
-0.10 \\
-1.20 \\
-0.21 \\
-1.39 \\
-0.28 \\
-0.81 \\
-0.15 \\
-0.77 \\
-0.09 \\
-1.54\end{array}$ \\
\hline $\begin{array}{l}\text { Mass change } \\
\text { term }\end{array}$ & 0.70925 & 0.54683 & 0.38393 & 0.37623 \\
\hline
\end{tabular}

Notes: $*=$ compared to chloritized Sample 158-957E-18R-1 (Piece 1, 4-7 cm); $* *=$ compared to chloritized precursor of same sample; gy = gray. Major elements are given in weight percent; trace and rare earth elements are given in parts per million. $\mathrm{Fe}_{2} \mathrm{O}_{3} *$ total iron as $\mathrm{Fe}_{2} \mathrm{O}_{3}$

sor. As can be seen from Table 7, the biggest impact is on the Fe and $\mathrm{S}$ fluxes; apart from these components, there is excellent agreement in the directions of elemental exchange and generally good agreement on the magnitudes of fluxes of the major element oxides.

\section{SUMMARY AND CONCLUSIONS}

A comparison of the magnitudes and directions of major element oxide and trace element fluxes for the three stages of alteration (i.e., chloritization, paragonitization, and silicification of basaltic basement in the shallowest portions of the stockwork beneath the active TAG mound [Figs. 10,11]) allows us to trace the history of elemental gains and losses during each step of the alteration sequence. The inclusion of quartz + pyrite in the alteration mineral assemblage at each step of the alteration sequence results in $\mathrm{SiO}_{2}, \mathrm{Fe}_{2} \mathrm{O}_{3}, \mathrm{~S}$, and Co showing a consistent (and positive) exchange direction throughout all stages of alteration, although the magnitudes of the exchanges are quite different. Almost all the other components show either complete removal during one type of alteration, or a change in the exchange direction during different steps in the alteration sequence. The changes associated with each stage of alteration can be summarized as follows: 


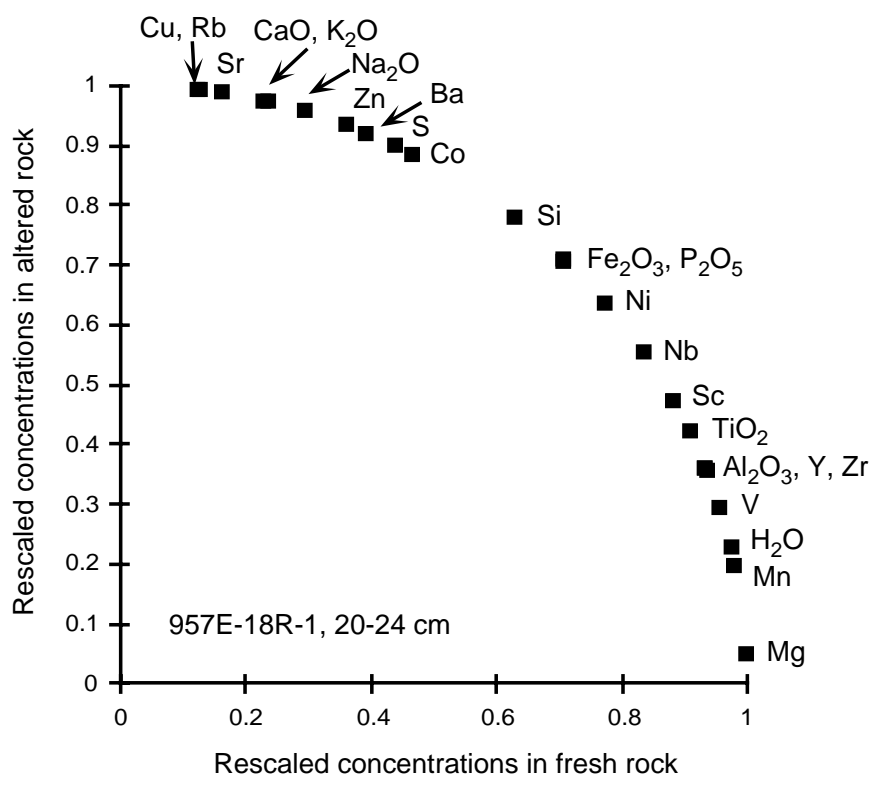

Figure 9. Rescaled concentration data for the silicified Sample 158-957E18R-1 (Piece 4, 20-24 cm). The concentration data have been standardized the same way as described for Figure 8. This illustrates that for intensely altered samples, the determination of a "relatively immobile" group of components (defined as components that cluster together) for calculation of a mass change term breaks down as all the components are widely scattered along the arc of the unit circle.

1. During the initial conversion of fresh basalt in the upflow zone to chlorite \pm quartz \pm pyrite by reactions between basalt and a hydrothermal fluid-seawater mixture, fluid-rock reactions resulted in uptake of $\mathrm{Al}_{2} \mathrm{O}_{3}, \mathrm{Fe}_{2} \mathrm{O}_{3}, \mathrm{MgO}, \mathrm{H}_{2} \mathrm{O}^{+}, \mathrm{S}, \mathrm{V}$, and Co. In addition, essentially all of the $\mathrm{CaO}, \mathrm{Na}_{2} \mathrm{O}$, and $\mathrm{Sr}$ were lost from the rock during alteration of plagioclase. The trace metals $\mathrm{Cu}, \mathrm{Ni}$, and $\mathrm{Zn}$ were leached from the rock, with almost all of the $\mathrm{Cu}$ being removed. $\mathrm{SiO}_{2}$ fluxes were variable in direction and in general quite small.

2. This was followed by replacement of the chlorite-rich assemblage by paragonite \pm quartz \pm pyrite during reactions with a hydrothermal fluid enriched in alkalis. This resulted in additional uptake of $\mathrm{SiO}_{2}, \mathrm{Fe}_{2} \mathrm{O}_{3}, \mathrm{~S}$, and $\mathrm{Co}$ as well as small amounts of $\mathrm{Na}_{2} \mathrm{O}, \mathrm{K}_{2} \mathrm{O}, \mathrm{Sr}, \mathrm{Ba}$, and $\mathrm{Zn}$. Other components were lost from the rock, including $\mathrm{MgO}, \mathrm{H}_{2} \mathrm{O}^{+}$, and $\mathrm{V}$, and small amounts of $\mathrm{Al}_{2} \mathrm{O}_{3}$.

3. Further silicification of the paragonite-rich assemblage resulted in continuing loss of $\mathrm{MgO}$ and $\mathrm{H}_{2} \mathrm{O}^{+}$, and almost complete loss of $\mathrm{V}$. This stage of the alteration sequence is also responsible for the largest increases in the $\mathrm{SiO}_{2}, \mathrm{Fe}_{2} \mathrm{O}_{3}, \mathrm{~S}$, and $\mathrm{Co}$ contents of the altered rocks, some of which showed gains in $\mathrm{Cu}$ and $\mathrm{Zn}$, presumably in association with the pyrite. Small gains in $\mathrm{Na}_{2} \mathrm{O}, \mathrm{K}_{2} \mathrm{O}, \mathrm{Ba}$, and $\mathrm{Sr}$ in a few samples may be related to the continued replacement of the rock by paragonite.

In terms of the internal structure of the deposit, these stages of alteration are observed in a vertical sequence, with the green chloritized basalts at the greatest depths drilled in the stockwork, grading into paragonitized basalt breccias, and then up into the zone of silicified wallrock breccias.

The presence of relatively fresh basalts and basalt interiors in the TAG-2 and TAG-4 areas implies that vigorous upflow and stockwork formation are confined to a narrow zone beneath the TAG mound, and hence the large chemical fluxes that are associated with the very

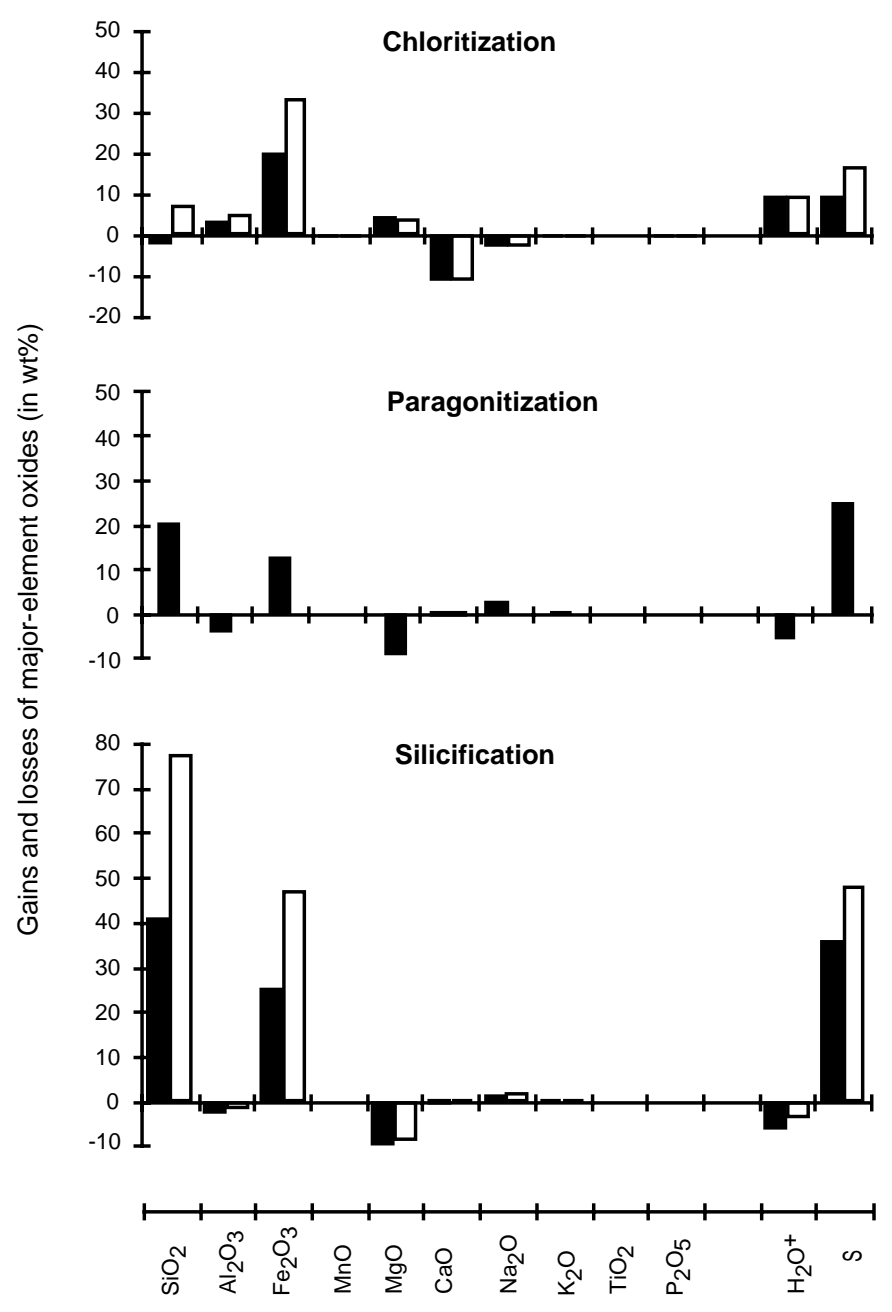

Figure 10. Gains and losses of major element oxides (in weight percent) calculated for the sequence of hydrothermal alteration of basaltic basement in the stockwork underlying the active TAG mound. The data for the two chlorite-rich assemblages are taken from Table 6; the data for the paragonite-rich assemblage is for Sample 158-957E-14R-1 (Piece 5, 17-20 cm) in Table 7; the two silicified samples are the remaining two samples in Table 7.

intense alteration affect only a relatively small volume of basalt. However, chloritization of halos and breccias provides evidence that high-temperature $\left(>200^{\circ} \mathrm{C}\right)$ water-rock reactions are occurring at these marginal sites, although the heterogeneous nature of the alteration indicates that hydrothermal flow is not pervasive or sustained beneath the margins of the mound. Differences in the magnitudes and directions of the $\mathrm{MgO}$ and $\mathrm{Fe}_{2} \mathrm{O}_{3}$ exchanges at these sites result from the formation of chlorites of different compositions, suggesting that temperatures and the composition of the reacting fluids are different at the periphery of the stockwork zone. Although the chemical changes associated with the chloritization reactions are not as great, the volume of basalt affected by such reactions is not currently known.

The chemical change calculations suggest that during alteration of the basalt within the upflow zone, most of the cations are leached from the rock. Many of these are retained within the stockwork during precipitation of secondary minerals within veins and other open spaces, others are precipitated from the discharging fluids or the hydrothermal plume, and still others provide an input of the dissolved component into seawater. It has been estimated that there are about $30,000-60,000$ tonnes of copper in the TAG mound and underlying 


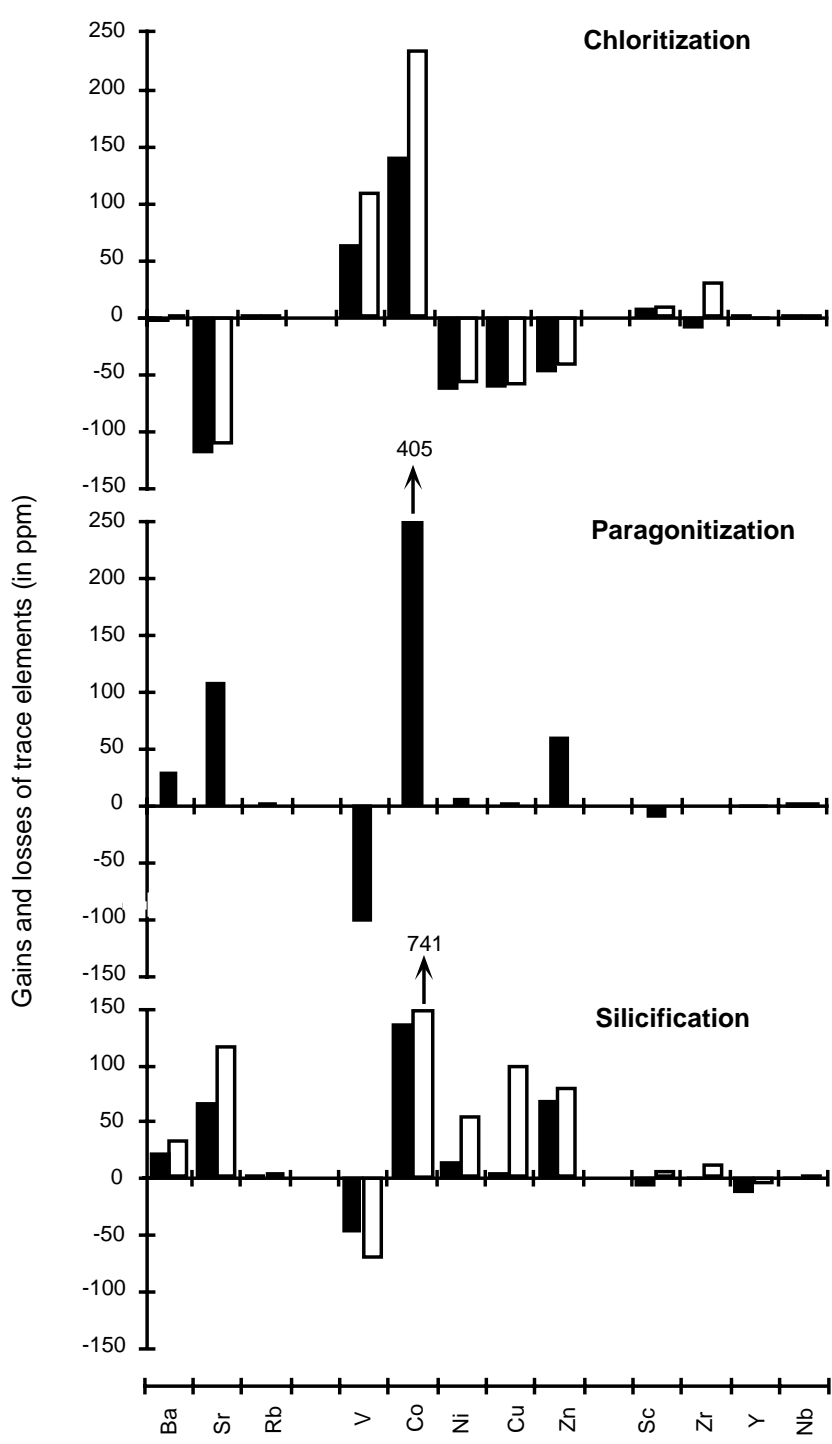

Figure 11. Gains and losses of trace elements (in parts per million) for the same samples as shown in Figure 10.

stockwork (Humphris et al., 1995). Our geochemical data suggest that essentially all of the $\mathrm{Cu}$ is leached from the basalt during alteration within the stockwork zone. Although there are no data for the $\mathrm{Cu}$ concentrations in black smoker fluids at TAG, values for other seafloor hydrothermal vents are typically quite low at $1-21 \mu \mathrm{mol} / \mathrm{kg}$ (Von Damm, 1995) suggesting that most of the $\mathrm{Cu}$ leached from the basalt is reprecipitated in the mound and stockwork. Hence, we can use the data presented here to estimate the minimum volume of basalt that must be altered in order to account for the amount of $\mathrm{Cu}$ in the mineral deposit. Using the average $\mathrm{Cu}$ content for fresh basalt of 73 ppm (Table 2) and assuming that all of it is leached during alteration, the amount of basalt that it is necessary to alter is $0.14-0.29 \mathrm{~km}^{3}$. The lateral extent of the shallowest parts of the upflow zone at the active TAG mound has been constrained by the drilling results to be about $150 \mathrm{~m}$ in diameter in an east-west direction (Humphris, Herzig, Miller, et al., 1996). If we assume a pipe-like upflow zone as seen in ancient deposits and a depth to the reaction zone of $2 \mathrm{~km}$ (Campbell et al., 1988), then the volume of basalt in the upflow zone is only about $0.04 \mathrm{~km}^{3}$ and hence cannot account for all of the $\mathrm{Cu}$ in the deposit. This implies that a considerably larger volume of basalt is be- ing highly altered at depth, which fits with observations from ophiolites and from other deep sea drill sites (Alt, 1994, 1995). Alternatively, alteration processes in the surrounding country rock, rather than directly in the upflow zone, that result in loss of $\mathrm{Cu}$ (such as the type of alteration observed at TAG-2) may play an important role in the development of a large mineral deposit on the seafloor.

\section{ACKNOWLEDGMENTS}

We thank Margaret Sulanowska for help in the laboratory, particularly with sample preparation, and Nancy Parmentier for running the CHNS analyzer. Discussions with G.P. Lohmann on modifications to the graphical representation of Grant's procedures were extremely helpful. Careful reviews by K. Gillis and C. Mevel greatly improved the manuscript. This study was supported by USSAC Grant 158-20882 to S. Humphris. This is WHOI Contribution No. 9396.

\section{REFERENCES}

Alt, J.C., 1994. A sulfur isotopic profile through the Troodos ophiolite, Cyprus: primary composition and the effects of seawater hydrothermal alteration. Geochim. Cosmochim. Acta, 58:1825-1840.

1995. Subseafloor processes in mid-ocean ridge hydrothermal systems. In Humphris, S.E., Zierenberg, R., Mullineaux, L., and Thomson, R. (Eds.), Seafloor Hydrothermal Systems: Physical, Chemical, Biological and Geological Interactions within Hydrothermal Systems. Geophys. Monogr., Am. Geophys. Union, 91:85-114.

Alt, J.C., Anderson, T.F., Bonnell, L., and Muehlenbachs, K., 1989. Mineralogy, chemistry, and stable isotopic compositions of hydrothermally altered sheeted dikes: ODP Hole 504B, Leg 111. In Becker, K., Sakai, H., et al., Proc. ODP, Sci. Results, 111: College Station, TX (Ocean Drilling Program), 27-40.

Alt, J.C., and Honnorez, J., 1984. Alteration of the upper oceanic crust, DSDP Site 417: mineralogy and chemistry. Contrib. Mineral. Petrol., 87:149-169.

Alt, J.C., Honnorez, J., Laverne, C., and Emmermann, R., 1986. Hydrothermal alteration of a $1 \mathrm{~km}$ section through the upper oceanic crust, Deep Sea Drilling Project Hole 504B: mineralogy, chemistry, and evolution of seawater-basalt interactions. J. Geophys. Res., 91:10309-10335.

Bettison-Varga, L., Varga, R.J., and Schiffman, P., 1992. Relation between ore-forming hydrothermal systems and extensional deformation in the Solea graben spreading center, Troodos ophiolite. Geology, 20:987-990.

Campbell, A.C., Palmer, M.R., Klinkhammer, G.P., Bowers, T.S., Edmond, J.M., Lawrence, J.R., Casey, J.F., Thompson, G., Humphris, S., Rona, P.A., and Karson, J.A., 1988. Chemistry of hot springs on the Mid-Atlantic Ridge. Nature, 335:514-519.

Collinson, T.B., 1986. Hydrothermal mineralization and basalt alteration in stockwork zones of the Bayda and Lasail massive sulfide deposits, Oman ophiolite [M.S. thesis]. Univ. of California, Santa Barbara.

Delaney, J.R., Mogk, D.W., and Mottl, M.J., 1987. Quartz-cemented breccias from the Mid-Atlantic Ridge: samples of a high-salinity hydrothermal upflow zone. J. Geophys. Res., 92:9175-9192.

Donnelly, T.W., Thompson, G., and Robinson, P.T., 1979. Very-low-temperature hydrothermal alteration of the oceanic crust and the problem of fluxes of potassium and magnesium. In Talwani, M., Harrison, C.G., and Hayes, D.E. (Eds.), Deep Drilling Results in the Atlantic Ocean: Ocean Crust. Am. Geophys. Union, 2:369-382.

Edmond, J.M., Campbell, A.C., Palmer, M.R., German, C.R., Klinkhammer, G.P., Edmonds, H.N., Elderfield, H., Thompson, G., and Rona, P., 1995. Time-series studies of vent fluids from the TAG and MARK sites (1986, 1990): Mid-Atlantic Ridge: a new solution chemistry model and a mechanism for $\mathrm{Cu} / \mathrm{Zn}$ zonation in massive sulfide ore bodies. In Parson, L.M., Walker, C.L., and Dixon, D.R. (Eds.), Hydrothermal Vents and Processes. Geol. Soc. Spec. Publ. London, 87:77-86.

Embley, R.W., Jonasson, I.R., Perfit, M.R., Franklin, J.M., Tivey, M.A. Malahoff, A., Smith, M.F., and Francis, T.J.G., 1988. Submersible investigation of an extinct hydrothermal system on the Galapagos Ridge: sulfide mounds, stockwork zone, and differentiated lavas. Can. Mineral., 26:517-539. 
Fouquet, Y., Wafik, A., Cambon, P., Mevel, C., Meyer, G., and Gente, P., 1993. Tectonic setting and mineralogical and geochemical zonation in the Snakepit sulphide deposit (Mid-Atlantic Ridge at $23^{\circ} \mathrm{N}$ ). Econ. Geol., 88:2018-2036.

Gillis, K.M., and Robinson, P.T., 1985. Low-temperature alteration of the extrusive sequence, Troodos ophiolite, Cyprus. Can. Mineral., 23:431441.

1990. Patterns and processes of alteration in the lavas and dykes of the Troodos Ophiolite, Cyprus. J. Geophys. Res., 95:21523-21548.

Gillis, K.M., Thompson, G., and Kelley, D.S., 1993. A view of the lower crustal component of hydrothermal systems at the Mid-Atlantic Ridge. $J$. Geophys. Res., 98:19597-19619.

Grant, J.A., 1986. The isocon diagram[0151]a simple solution to Gresen's equation for metasomatic alteration. Econ. Geol., 81:1976-1982.

Gresens, R.L., 1967. Composition-volume relationships of metasomatism. Chem. Geol., 2:47-65.

Harper, G.D., Bowman, J.R., and Kuhns, R.J., 1988. A field, chemical, and stable isotope study of subseafloor metamorphism of the Josephine Ophiolite, California-Oregon. J. Geophys. Res., 93:4625-4656.

Hart, R.A., 1970. Chemical exchange between seawater and deep ocean basalts. Earth Planet. Sci. Lett., 9:269-279.

Hart, S.R., and Staudigel, H., 1982. The control of alkalies and uranium in sea water by ocean crust alteration. Earth Planet. Sci. Lett., 58:202-212.

Humphris, S.E., Herzig, P.M., Miller, D.J., Alt, J.C., Becker, K., Brown, D., Brügmann, G., Chiba, H., Fouquet, Y., Gemmell, J.B., Guerin, G., Hannington, M.D., Holm, N.G., Honnorez, J.J., Itturino, G.J., Knott, R., Ludwig, R., Nakamura, K., Petersen, S., Reysenbach, A.-L., Rona, P.A., Smith, S., Sturz, A.A., Tivey, M.K., and Zhao, X., 1995. The internal structure of an active sea-floor massive sulphide deposit. Nature, 377:713-716

Humphris, S.E., Herzig, P.M., Miller, D.J., et al., 1996. Proc. ODP, Init. Repts., 158: College Station, TX (Ocean Drilling Program).

Humphris, S.E., and Kleinrock, M.C., 1996. Detailed morphology of the TAG active hydrothermal mound: insights into its formation and growth, Geophy. Res. Lett., 23:3443-3446.

Humphris, S.E., and Thompson, G., 1978a. Hydrothermal alteration of oceanic basalts by seawater. Geochim. Cosmochim. Acta, 42:107-125.

, 1978b. Trace element mobility during hydrothermal alteration of oceanic basalts. Geochim. Cosmochim. Acta, 42:127-136.

Kleinrock, M.C., and Humphris, S.E., 1996. Structural controls on the localization of seafloor hydrothermal activity at the TAG active mound, MidAtlantic Ridge. Nature, 382:149-153.

Kleinrock, M.C., Humphris, S.E., and the Deep-TAG Team, 1996. Detailed structure and morphology of the TAG active hydrothermal mound and its geotectonic environment. In Humphris, S.E., Herzig, P.M., Miller, D.J., et al., Proc. ODP, Init. Repts., 158: College Station, TX (Ocean Drilling Program), 15-21.

Klinkhammer, G.P., Elderfield, H., Edmond, J.M., and Mitra, A., 1994. Geochemical implications of rare earth elements patterns in hydrothermal fluids from mid-ocean ridges. Geochim. Cosmochim. Acta, 58:51055113.

Lalou, C., Reyss, J.L., Brichet, E., Arnold, M., Thompson, G., Fouquet, Y., and Rona, P.A., 1993. New age data for Mid-Atlantic Ridge hydrothermal sites: TAG and Snakepit geochronology revisited. J. Geophys. Res., 98:9705-9713.

Lalou, C., Thompson, G., Arnold, M., Brichet, E., Druffel, E., and Rona, P.A., 1990. Geochronology of TAG and Snakepit hydrothermal fields, Mid-Atlantic Ridge: witness to a long and complex hydrothermal history. Earth Planet. Sci. Lett., 97:113-128.

Lydon, J.W., and Galley, A.G., 1986. The chemical and mineralogical zonation of the Mathiati alteration pipe, Cyprus and its genetic significance. In Gallagher, M.J., Ixer, R.A., Neary, C.R., and Prichard, H.M. (Eds.),
Metallogeny of Basic and Ultrabasic Rocks. London Inst. Min. Metall., 46-68.

Nehlig, P., Juteau, T., Bendel, V., and Cotten, J., 1994. The root zone of oceanic hydrothermal systems: constraints from the Samail ophiolite (Oman). J. Geophys. Res., 99:4703-4713.

Richards, H.G., Cann, J.R., and Jensensius, J., 1989. Mineralogical zonation and metasomatism of the alteration pipes of Cyprus sulfide deposits. Econ. Geol., 84:91-115.

Richardson, C.J., Cann, J.R., Richards, H.G., and Cowan, J.G., 1987. Metaldepleted root zones of the Troodos ore-forming hydrothermal systems, Cyprus. Earth Planet. Sci. Lett., 84:243-253.

Ridley, W.I., Perfit, M.R., Jonasson, I.R., and Smith, M.F., 1994. Hydrothermal alteration in oceanic ridge volcanics: a detailed study at the Galapagos fossil hydrothermal field. Geochim. Cosmochim. Acta, 58:24772494.

Rona, P.A., Bogdanov, Y.A., Gurvich, E.G., Rimski-Korsakov, A., Sagalevitch, A.M., Hannington, M.D., and Thompson, G., 1993a. Relict hydrothermal zones in the TAG hydrothermal field, Mid-Atlantic Ridge $26^{\circ} \mathrm{N}$, $45^{\circ}$ W. J. Geophys. Res., 98:9715-9730.

Rona, P.A., Hannington, M.D., Raman, C.V., Thompson, G., Tivey, M.K., Humphris, S.E., Lalou, C., and Petersen, S., 1993b. Active and relict seafloor hydrothermal mineralization at the TAG hydrothermal field, MidAtlantic Ridge. Econ. Geol., 88:1987-2013.

Saccocia, P.J., and Gillis, K.M., 1995. Hydrothermal upflow zones in the oceanic crust. Earth Planet. Sci. Lett., 136:1-16.

Schiffman, P., and Smith, B.M., 1988. Petrology and oxygen isotope geochemistry of a fossil seawater hydrothermal system within the Solea Graben, northern Troodos ophiolite, Cyprus. J. Geophys. Res., 93:46124624.

Thompson, G., 1973. A geochemical study of the low-temperature interaction of sea-water and oceanic igneous rocks. Eos, 54:1015-1019.

1983. Basalt-seawater interaction. In Rona, P.A., Boström, K. Laubier, L., and Smith, K.L., Jr. (Eds.), Hydrothermal Processes at Seafloor Spreading Centers: New York (Plenum), 225-278.

Thompson, G., Humphris, S.E., Schroeder, B., Sulanowska, M., and Rona, P.A., 1988. Active vents and massive sulfides at $26^{\circ} \mathrm{N}$ (TAG) and $23^{\circ} \mathrm{N}$ (Snakepit) on the Mid-Atlantic Ridge. Can. Mineral., 26:697-711.

Tivey, M.A., Rona, P.A., and Schouten, H., 1993. Reduced crustal magnetization beneath the active sulfide mound, TAG hydrothermal field, MidAtlantic Ridge $26^{\circ}$ N. Earth Planet. Sci. Lett., 115:101-115.

Tivey, M.K., Humphris, S.E., Thompson, G., Hannington, M.D., and Rona, P.A., 1995. Deducing patterns of fluid flow and mixing within the TAG active hydrothermal mound using mineralogical and geochemical data. $J$. Geophys. Res., 100:12527-12555.

Von Damm, K.L., 1995. Controls on the chemistry and temporal variability of seafloor hydrothermal fluids. In Humphris, S.E., Zierenberg, R.A., Mullineaux, L.S., and Thomson, R.E. (Eds.), Seafloor Hydrothermal Systems: Physical, Chemical, Biological, and Geological Interactions. Am. Geophys. Union, 91:222-247.

Zierenberg, R.A., Schiffman, P., Jonasson, I.R., Tosdal, R., Pickthorn, W., and McClain, J., 1995. Alteration of basalt hyaloclastite at off-axis Sea Cliff hydrothermal field, Gorda Ridge. Chem. Geol., 126:77-99.

Zierenberg, R.A., Shanks, W.C., III, Seyfried, W.E., Jr., Koski, R.A., and Strickler, M.D., 1988. Mineralization, alteration, and hydrothermal metamorphism of the ophiolite-hosted Turner-Albright sulfide deposits, southwestern Oregon. J. Geophys. Res., 93:4657-4674.

\section{Date of initial receipt: 3 June 1996 \\ Date of acceptance: 4 April 1997 \\ Ms 158SR-220}


Appendix Table 1. Analyses of standard reference materials for major element oxides and selected trace element analyses by ICP-ES.

\begin{tabular}{|c|c|c|c|c|c|c|c|c|c|c|c|c|c|c|}
\hline Standard ID & $\begin{array}{l}\text { Source of } \\
\text { standard }\end{array}$ & $\begin{array}{c}\mathrm{SiO}_{2} \\
(\mathrm{wt} \%)\end{array}$ & $\begin{array}{l}\mathrm{Al}_{2} \mathrm{O}_{3} \\
(\mathrm{wt} \%)\end{array}$ & $\begin{array}{l}\mathrm{Fe}_{2} \mathrm{O}_{3} * \\
(\mathrm{wt} \%)\end{array}$ & $\begin{array}{l}\mathrm{MnO} \\
(\mathrm{wt} \%)\end{array}$ & $\begin{array}{l}\mathrm{MgO} \\
(\mathrm{wt} \%)\end{array}$ & $\begin{array}{l}\mathrm{CaO} \\
(\mathrm{wt} \%)\end{array}$ & $\begin{array}{l}\mathrm{Na}_{2} \mathrm{O} \\
(\mathrm{wt} \%)\end{array}$ & $\begin{array}{c}\mathrm{K}_{2} \mathrm{O} \\
(\mathrm{wt} \%)\end{array}$ & $\begin{array}{l}\mathrm{TiO}_{2} \\
(\mathrm{wt} \%)\end{array}$ & $\begin{array}{l}\mathrm{P}_{2} \mathrm{O}_{5} \\
(\mathrm{wt} \%)\end{array}$ & $\begin{array}{c}\mathrm{Ba} \\
(\mathrm{ppm})\end{array}$ & $\begin{array}{c}\mathrm{Sc} \\
(\mathrm{ppm})\end{array}$ & $\begin{array}{c}\mathrm{V} \\
(\mathrm{ppm})\end{array}$ \\
\hline $\begin{array}{l}\text { SY-3 } \\
\text { Reference values }\end{array}$ & CCRMP & $\begin{array}{l}59.51 \\
\underline{59.68} \\
\end{array}$ & $\begin{array}{l}11.62 \\
11.76 \\
\end{array}$ & $\begin{array}{l}6.47 \\
6.54 \\
\end{array}$ & $\begin{array}{l}0.32 \\
\underline{0.32} \\
\end{array}$ & $\begin{array}{l}2.54 \\
2.67 \\
\end{array}$ & $\begin{array}{l}8.25 \\
8.25 \\
\end{array}$ & $\begin{array}{l}4.17 \\
4.12 \\
\end{array}$ & $\begin{array}{l}4.23 \\
4.23 \\
\end{array}$ & $\begin{array}{l}0.14 \\
\underline{0.15}\end{array}$ & $\begin{array}{l}0.52 \\
0.54 \\
\end{array}$ & $\begin{array}{l}435 \\
450 \\
\end{array}$ & $\begin{array}{l}8 \\
6.8\end{array}$ & $\begin{array}{l}45 \\
50\end{array}$ \\
\hline $\begin{array}{l}\text { MRG-1 } \\
\text { Reference values }\end{array}$ & CCRMP & $\begin{array}{l}39.43 \\
39.12 \\
\end{array}$ & $\begin{array}{l}8.59 \\
8.47 \\
\end{array}$ & $\begin{array}{l}17.93 \\
17.97\end{array}$ & $\begin{array}{l}0.17 \\
0.17 \\
\end{array}$ & $\begin{array}{l}13.74 \\
13.55 \\
\end{array}$ & $\begin{array}{l}14.77 \\
14.7\end{array}$ & $\begin{array}{l}0.73 \\
0.74 \\
\end{array}$ & $\begin{array}{l}0.18 \\
0.18 \\
\end{array}$ & $\begin{array}{l}3.78 \\
3.77\end{array}$ & $\begin{array}{l}0.07 \\
0.08 \\
\end{array}$ & $\begin{array}{l}48 \\
61 \\
\end{array}$ & $\begin{array}{l}55 \\
55 \\
\end{array}$ & $\begin{array}{l}521 \\
526 \\
\end{array}$ \\
\hline $\begin{array}{l}\text { DNC-1 } \\
\text { Reference values }\end{array}$ & USGS & $\begin{array}{l}46.91 \\
47.04 \\
\end{array}$ & $\begin{array}{l}18.45 \\
\underline{18.3}\end{array}$ & $\begin{array}{l}9.76 \\
9.96 \\
\end{array}$ & $\begin{array}{l}0.15 \\
0.15 \\
\end{array}$ & $\begin{array}{l}10.05 \\
\underline{10.05} \\
\end{array}$ & $\begin{array}{l}11.27 \\
11.27 \\
\end{array}$ & $\begin{array}{l}1.99 \\
1.87 \\
\end{array}$ & $\begin{array}{l}0.24 \\
\underline{0.23} \\
\end{array}$ & $\begin{array}{l}0.47 \\
0.48 \\
\end{array}$ & $\begin{array}{l}0.07 \\
\underline{0.09}\end{array}$ & $\begin{array}{l}102 \\
114 \\
\end{array}$ & $\begin{array}{l}31 \\
31 \\
\end{array}$ & $\begin{array}{l}143 \\
148 \\
\end{array}$ \\
\hline $\begin{array}{l}\text { BIR-1 } \\
\text { Reference values }\end{array}$ & USGS & $\begin{array}{l}47.78 \\
47.77\end{array}$ & $\begin{array}{l}15.43 \\
15.35 \\
\end{array}$ & $\begin{array}{l}11.52 \\
11.38 \\
\end{array}$ & $\begin{array}{l}0.17 \\
0.17 \\
\end{array}$ & $\begin{array}{l}9.7 \\
2.68\end{array}$ & $\begin{array}{l}13.75 \\
13.24\end{array}$ & $\begin{array}{l}1.96 \\
1.75\end{array}$ & $\begin{array}{l}0.02 \\
0.03\end{array}$ & $\begin{array}{l}0.95 \\
0.96 \\
\end{array}$ & $\begin{array}{r}0.02 \\
(0.05\end{array}$ & $\begin{array}{l}7 \\
7\end{array}$ & $\begin{array}{l}44 \\
44 \\
\end{array}$ & $\begin{array}{l}321 \\
313 \\
\end{array}$ \\
\hline $\begin{array}{l}\text { W-2 } \\
\text { Reference values }\end{array}$ & USGS & $\begin{array}{l}52.58 \\
52.44 \\
\end{array}$ & $\begin{array}{l}15.35 \\
15.35 \\
\end{array}$ & $\begin{array}{l}10.72 \\
10.74 \\
\end{array}$ & $\begin{array}{l}0.16 \\
\underline{0.16} \\
\end{array}$ & $\begin{array}{l}6.37 \\
6.37 \\
\end{array}$ & $\begin{array}{l}10.98 \\
10.87 \\
\end{array}$ & $\begin{array}{l}2.31 \\
2.14 \\
\end{array}$ & $\begin{array}{l}0.64 \\
\underline{0.63} \\
\end{array}$ & $\begin{array}{l}1.05 \\
1.06 \\
\end{array}$ & $\begin{array}{l}0.12 \\
\underline{0.131} \\
\end{array}$ & $\begin{array}{l}170 \\
182 \\
\end{array}$ & $\begin{array}{l}35 \\
\underline{35} \\
\end{array}$ & $\begin{array}{l}268 \\
262 \\
\end{array}$ \\
\hline $\begin{array}{l}\text { G-2 } \\
\text { Reference values }\end{array}$ & USGS & $\begin{array}{l}68.72 \\
69.14 \\
\end{array}$ & $\begin{array}{l}14.95 \\
15.39\end{array}$ & $\begin{array}{l}2.65 \\
2.69\end{array}$ & $\begin{array}{l}0.03 \\
0.03 \\
\end{array}$ & $\begin{array}{l}0.71 \\
0.75 \\
\end{array}$ & $\begin{array}{l}1.87 \\
1.96 \\
\end{array}$ & $\begin{array}{l}4.08 \\
4.08 \\
\end{array}$ & $\begin{array}{l}4.48 \\
4.48\end{array}$ & $\begin{array}{l}0.48 \\
0.48 \\
\end{array}$ & $\begin{array}{l}0.13 \\
0.14\end{array}$ & $\begin{array}{l}1882 \\
1882 \\
\end{array}$ & $\begin{array}{l}3 \\
3.5 \\
\end{array}$ & $\begin{array}{r}3 \\
36 \\
\end{array}$ \\
\hline $\begin{array}{l}\text { STM-1 } \\
\text { Reference values }\end{array}$ & USGS & $\begin{array}{l}59.64 \\
59.64 \\
\end{array}$ & $\begin{array}{l}18.07 \\
18.39 \\
\end{array}$ & $\begin{array}{l}5.24 \\
5.19 \\
\end{array}$ & $\begin{array}{l}0.22 \\
0.22 \\
\end{array}$ & $\begin{array}{l}0.07 \\
\underline{0.1}\end{array}$ & $\begin{array}{l}1.09 \\
1.09 \\
\end{array}$ & $\begin{array}{l}8.87 \\
8.94 \\
\end{array}$ & $\begin{array}{l}4.24 \\
4.28 \\
\end{array}$ & $\begin{array}{l}0.13 \\
0.14 \\
\end{array}$ & $\begin{array}{l}0.16 \\
\underline{0.16} \\
\end{array}$ & $\begin{array}{l}583 \\
560 \\
\end{array}$ & $\begin{array}{l}<1 \\
\underline{0.61}\end{array}$ & $\begin{array}{c}4 \\
(8.7\end{array}$ \\
\hline $\begin{array}{l}\text { BHVO-1 } \\
\text { Reference values }\end{array}$ & USGS & $\begin{array}{l}49.18 \\
49.94 \\
\end{array}$ & $\begin{array}{l}12.98 \\
13.8\end{array}$ & $\begin{array}{l}12.37 \\
12.34\end{array}$ & $\begin{array}{l}0.18 \\
0.17\end{array}$ & $\begin{array}{l}7.1 \\
7.23 \\
\end{array}$ & $\begin{array}{l}12.23 \\
11.4\end{array}$ & $\begin{array}{l}2.15 \\
2.26\end{array}$ & $\begin{array}{l}0.52 \\
0.52 \\
\end{array}$ & $\begin{array}{l}2.94 \\
2.71\end{array}$ & $\begin{array}{l}0.28 \\
0.27\end{array}$ & $\begin{array}{l}130 \\
139 \\
\end{array}$ & $\begin{array}{l}33 \\
31.8\end{array}$ & $\begin{array}{l}326 \\
317\end{array}$ \\
\hline $\begin{array}{l}\text { FER-3 } \\
\text { Reference values }\end{array}$ & CCRMP & $\begin{array}{l}52.56 \\
53.39 \\
\end{array}$ & $\begin{array}{l}0.1 \\
\underline{0.08} \\
\end{array}$ & $\begin{array}{l}42.7 \\
43.37 \\
\end{array}$ & $\begin{array}{l}0.08 \\
\underline{0.08} \\
\end{array}$ & $\begin{array}{l}0.85 \\
1.02 \\
\end{array}$ & $\begin{array}{l}0.77 \\
\underline{0.83} \\
\end{array}$ & $\begin{array}{l}0.01 \\
0.01 \\
\end{array}$ & $\begin{array}{l}0.01 \\
\underline{0.02}\end{array}$ & $\begin{array}{r}<0.01 \\
\underline{0.01}\end{array}$ & $\begin{array}{l}0.06 \\
0.07 \\
\end{array}$ & $\begin{array}{l}10 \\
11 \\
\end{array}$ & $\begin{array}{c}<1 \\
0.6\end{array}$ & $\begin{array}{l}5 \\
\underline{8}\end{array}$ \\
\hline
\end{tabular}

Notes: $\mathrm{Fe}_{2} \mathrm{O}_{3} *=$ total iron as $\mathrm{Fe}_{2} \mathrm{O}_{3}$. CCRMP = Canadian Certified Reference Materials Project; USGS = U.S. Geological Survey. Underline = recommended values; other values are proposed except those preceded by a "(", which are information values.

Appendix Table 2. Analyses of trace elements in standard reference materials by ICP-MS.

\begin{tabular}{|c|c|c|c|c|c|c|c|c|c|c|}
\hline Sample ID & $\begin{array}{l}\text { Source of } \\
\text { standard }\end{array}$ & $\begin{array}{c}\mathrm{Sr} \\
(\mathrm{ppm})\end{array}$ & $\begin{array}{c}\mathrm{Rb} \\
(\mathrm{ppm})\end{array}$ & $\begin{array}{c}\mathrm{Co} \\
(\mathrm{ppm})\end{array}$ & $\begin{array}{c}\mathrm{Ni} \\
(\mathrm{ppm})\end{array}$ & $\underset{(\mathrm{ppm})}{\mathrm{Cu}}$ & $\underset{(\mathrm{ppm})}{\mathrm{Zn}}$ & $\begin{array}{c}\mathrm{Zr} \\
(\mathrm{ppm})\end{array}$ & $\begin{array}{c}\mathrm{Y} \\
(\mathrm{ppm})\end{array}$ & $\begin{array}{c}\mathrm{Nb} \\
(\mathrm{ppm})\end{array}$ \\
\hline $\begin{array}{l}\text { RGM-1 } \\
\text { Reference values }\end{array}$ & USGS & $\begin{array}{l}103 \\
108\end{array}$ & $\begin{array}{l}146 \\
149\end{array}$ & $\begin{array}{l}2.5 \\
2\end{array}$ & $\begin{array}{c}7 \\
(4.4\end{array}$ & $\begin{array}{l}11 \\
11.6\end{array}$ & $\begin{array}{l}30 \\
32\end{array}$ & $\begin{array}{l}182 \\
219\end{array}$ & $\begin{array}{l}22.3 \\
25\end{array}$ & $\begin{array}{l}5.67 \\
8.9\end{array}$ \\
\hline $\begin{array}{l}\text { STM-1 } \\
\text { Reference values }\end{array}$ & USGS & $\begin{array}{l}676 \\
700 \\
\end{array}$ & $\begin{array}{l}115 \\
118 \\
\end{array}$ & $\begin{array}{l}1 \\
0.61 \\
\end{array}$ & $\begin{array}{l}<5 \\
(3\end{array}$ & $\begin{array}{l}<5 \\
(4.6\end{array}$ & $\begin{array}{l}227 \\
235 \\
\end{array}$ & $\begin{array}{l}1204 \\
1210 \\
\end{array}$ & $\begin{array}{l}45.2 \\
46\end{array}$ & $\begin{array}{l}258 \\
268 \\
\end{array}$ \\
\hline $\begin{array}{l}\text { MAG-1 } \\
\text { Reference values }\end{array}$ & USGS & $\begin{array}{l}142 \\
146\end{array}$ & $\begin{array}{l}151 \\
149\end{array}$ & $\begin{array}{l}21.3 \\
20.4\end{array}$ & $\begin{array}{l}51 \\
53\end{array}$ & $\begin{array}{l}30 \\
30 \\
\end{array}$ & $\begin{array}{l}120 \\
130\end{array}$ & $\begin{array}{l}132 \\
126\end{array}$ & $\begin{array}{l}27 \\
28\end{array}$ & $\begin{array}{l}15.8 \\
12\end{array}$ \\
\hline $\begin{array}{l}\text { BIR-1 } \\
\text { Reference values }\end{array}$ & USGS & $\begin{array}{l}105 \\
108 \\
\end{array}$ & $\begin{array}{l}0.78 \\
0.25 \\
\end{array}$ & $\begin{array}{l}50.3 \\
51.4 \\
\end{array}$ & $\begin{array}{l}159 \\
166 \\
\end{array}$ & $\begin{array}{l}122 \\
126 \\
\end{array}$ & $\begin{array}{l}73 \\
71 \\
\end{array}$ & $\begin{array}{l}16 \\
16 \\
\end{array}$ & $\begin{array}{l}15 \\
16 \\
\end{array}$ & $\begin{array}{l}1.25 \\
0.6\end{array}$ \\
\hline $\begin{array}{l}\text { DNC-1 } \\
\text { Reference values }\end{array}$ & USGS & $\begin{array}{l}150 \\
145\end{array}$ & $\begin{array}{r}4.0 \\
(4.5\end{array}$ & $\begin{array}{l}57.2 \\
54.7\end{array}$ & $\begin{array}{l}250 \\
247\end{array}$ & $\begin{array}{r}102 \\
96 \\
\end{array}$ & $\begin{array}{l}70 \\
66 \\
\end{array}$ & $\begin{array}{l}42 \\
41\end{array}$ & $\begin{array}{l}17.7 \\
18\end{array}$ & $\begin{array}{l}1.91 \\
3\end{array}$ \\
\hline $\begin{array}{l}\text { W-2 } \\
\text { Reference values }\end{array}$ & USGS & $\begin{array}{l}199 \\
194 \\
\end{array}$ & $\begin{array}{l}21 \\
20 \\
\end{array}$ & $\begin{array}{l}41.7 \\
44\end{array}$ & $\begin{array}{l}67 \\
70 \\
\end{array}$ & $\begin{array}{l}103 \\
103 \\
\end{array}$ & $\begin{array}{l}70 \\
77 \\
\end{array}$ & $\begin{array}{r}101 \\
94\end{array}$ & $\begin{array}{l}21.9 \\
\underline{24}\end{array}$ & $\begin{array}{l}8.04 \\
7.9\end{array}$ \\
\hline $\begin{array}{l}\text { SY-2 } \\
\text { Reference values }\end{array}$ & CCRMP & $\begin{array}{l}264 \\
271\end{array}$ & $\begin{array}{l}219 \\
217\end{array}$ & $\begin{array}{l}8.5 \\
8.6\end{array}$ & $\begin{array}{l}6 \\
9.9\end{array}$ & $\begin{array}{l}7 \\
5.2\end{array}$ & $\begin{array}{l}257 \\
248\end{array}$ & $\begin{array}{l}286 \\
280\end{array}$ & $\begin{array}{l}126.9 \\
128\end{array}$ & $\begin{array}{l}31.6 \\
29\end{array}$ \\
\hline $\begin{array}{l}\text { SY-3 } \\
\text { Reference values }\end{array}$ & CCRMP & $\begin{array}{l}309 \\
302 \\
\end{array}$ & $\begin{array}{l}211 \\
206 \\
\end{array}$ & $\begin{array}{l}9.7 \\
8.8\end{array}$ & $\begin{array}{l}19 \\
11\end{array}$ & $\begin{array}{l}20 \\
17\end{array}$ & $\begin{array}{l}262 \\
244 \\
\end{array}$ & $\begin{array}{l}326 \\
320\end{array}$ & $\begin{array}{l}720.5 \\
718\end{array}$ & $\begin{array}{l}161 \\
148\end{array}$ \\
\hline $\begin{array}{l}\text { GXR-1 } \\
\text { Reference values }\end{array}$ & USGS & $\begin{array}{l}292 \\
275\end{array}$ & $\begin{array}{l}4.3 \\
(14\end{array}$ & $\begin{array}{r}14.1 \\
8.2\end{array}$ & $\begin{array}{l}49 \\
41\end{array}$ & $\begin{array}{l}1108 \\
1110\end{array}$ & $\begin{array}{l}750 \\
760\end{array}$ & $\begin{array}{r}42 \\
(38\end{array}$ & $\begin{array}{l}30.6 \\
32\end{array}$ & $\begin{array}{l}3.31 \\
(0.8\end{array}$ \\
\hline $\begin{array}{l}\text { MRG-1 } \\
\text { Reference values }\end{array}$ & CCRMP & $\begin{array}{l}268 \\
266 \\
\end{array}$ & $\begin{array}{l}8.0 \\
8.5\end{array}$ & $\begin{array}{l}83.1 \\
\underline{87}\end{array}$ & $\begin{array}{l}180 \\
193 \\
\end{array}$ & $\begin{array}{l}127 \\
134 \\
\end{array}$ & $\begin{array}{l}175 \\
191 \\
\end{array}$ & $\begin{array}{l}107 \\
108 \\
\end{array}$ & $\begin{array}{l}12.7 \\
14\end{array}$ & $\begin{array}{l}22.8 \\
20\end{array}$ \\
\hline $\begin{array}{l}\text { BHVO-1 } \\
\text { Reference values }\end{array}$ & USGS & $\begin{array}{l}390 \\
403 \\
\end{array}$ & $\begin{array}{l}8.8 \\
11\end{array}$ & $\begin{array}{l}46.4 \\
45\end{array}$ & $\begin{array}{l}134 \\
121\end{array}$ & $\begin{array}{l}147 \\
136 \\
\end{array}$ & $\begin{array}{l}124 \\
130 \\
\end{array}$ & $\begin{array}{l}133 \\
126\end{array}$ & $\begin{array}{l}25.3 \\
27.6\end{array}$ & $\begin{array}{l}16 \\
19\end{array}$ \\
\hline $\begin{array}{l}\text { FER-3 } \\
\text { Reference values }\end{array}$ & CCRMP & $\begin{array}{l}33 \\
31\end{array}$ & $\begin{array}{l}0.58 \\
\text { NV }\end{array}$ & $\begin{array}{l}3.6 \\
\underline{2}\end{array}$ & $\begin{array}{l}46 \\
14 \\
\end{array}$ & $\begin{array}{r}19 \\
4.5 \\
\end{array}$ & $\begin{array}{l}35 \\
35 \\
\end{array}$ & $\begin{array}{l}2 \\
2\end{array}$ & $\begin{array}{l}3.6 \\
\underline{6}\end{array}$ & $\begin{array}{l}0.88 \\
\mathrm{NV}\end{array}$ \\
\hline
\end{tabular}

Notes: CCRMP = Canadian Certified Reference Materials Project; USGS = U.S. Geological Survey. Underline = recommended values; other values are proposed except for those preceded by a "(" which are information values. NV = no value. 
Appendix Table 3. Analyses of rare earth elements in standard reference materials by ICP-MS.

\begin{tabular}{|c|c|c|c|c|c|c|c|c|c|c|c|c|c|c|c|c|}
\hline Sample ID & $\begin{array}{l}\text { Source of } \\
\text { standard }\end{array}$ & $\begin{array}{c}\mathrm{La} \\
(\mathrm{ppm})\end{array}$ & $\begin{array}{c}\mathrm{Ce} \\
(\mathrm{ppm})\end{array}$ & $\begin{array}{c}\mathrm{Pr} \\
(\mathrm{ppm})\end{array}$ & $\begin{array}{c}\mathrm{Nd} \\
(\mathrm{ppm})\end{array}$ & $\begin{array}{c}\mathrm{Sm} \\
(\mathrm{ppm})\end{array}$ & $\begin{array}{c}\mathrm{Eu} \\
(\mathrm{ppm})\end{array}$ & $\begin{array}{c}\mathrm{Gd} \\
(\mathrm{ppm})\end{array}$ & $\begin{array}{c}\mathrm{Tb} \\
(\mathrm{ppm})\end{array}$ & $\begin{array}{c}\text { Dy } \\
(\mathrm{ppm})\end{array}$ & $\begin{array}{c}\mathrm{Ho} \\
(\mathrm{ppm})\end{array}$ & $\begin{array}{c}\text { Er } \\
(\mathrm{ppm})\end{array}$ & $\begin{array}{c}\mathrm{Tm} \\
(\mathrm{ppm})\end{array}$ & $\begin{array}{c}\mathrm{Yb} \\
(\mathrm{ppm})\end{array}$ & $\begin{array}{c}\mathrm{Lu} \\
(\mathrm{ppm})\end{array}$ & $\begin{array}{c}\mathrm{Hf} \\
(\mathrm{ppm})\end{array}$ \\
\hline $\begin{array}{l}\text { RGM-1 } \\
\text { Reference values }\end{array}$ & USGS & $\begin{array}{l}25.54 \\
24.00\end{array}$ & $\begin{array}{l}45.05 \\
47.00\end{array}$ & $\begin{array}{l}4.40 \\
4.70\end{array}$ & $\begin{array}{l}17.80 \\
19.00\end{array}$ & $\begin{array}{l}3.74 \\
4.30\end{array}$ & $\begin{array}{l}0.53 \\
0.66\end{array}$ & $\begin{array}{l}3.47 \\
3.70\end{array}$ & $\begin{array}{l}0.64 \\
0.66\end{array}$ & $\begin{array}{l}3.25 \\
4.08\end{array}$ & $\begin{array}{l}0.71 \\
0.95\end{array}$ & $\begin{array}{l}2.30 \\
2.60\end{array}$ & $\begin{array}{l}0.38 \\
0.37\end{array}$ & $\begin{array}{l}2.49 \\
2.60\end{array}$ & $\begin{array}{l}0.38 \\
0.41\end{array}$ & $\begin{array}{l}4.23 \\
6.20\end{array}$ \\
\hline $\begin{array}{l}\text { STM-1 } \\
\text { Reference values }\end{array}$ & USGS & $\begin{array}{l}144.32 \\
150.00\end{array}$ & $\begin{array}{l}250.90 \\
259.00\end{array}$ & $\begin{array}{l}20.51 \\
19.00\end{array}$ & $\begin{array}{l}76.61 \\
79.00\end{array}$ & $\begin{array}{l}12.68 \\
12.60\end{array}$ & $\begin{array}{l}3.31 \\
3.60\end{array}$ & $\begin{array}{r}10.51 \\
9.50\end{array}$ & $\begin{array}{l}1.55 \\
1.55\end{array}$ & $\begin{array}{l}7.67 \\
8.10\end{array}$ & $\begin{array}{l}1.46 \\
0.62\end{array}$ & $\begin{array}{l}4.26 \\
4.20\end{array}$ & $\begin{array}{l}0.66 \\
0.69\end{array}$ & $\begin{array}{l}4.20 \\
4.40\end{array}$ & $\begin{array}{l}0.63 \\
0.32\end{array}$ & $\begin{array}{l}28.74 \\
28.00\end{array}$ \\
\hline $\begin{array}{l}\text { MAG-1 } \\
\text { Reference values }\end{array}$ & USGS & $\begin{array}{l}41.08 \\
43.00\end{array}$ & $\begin{array}{l}85.15 \\
88.00\end{array}$ & $\begin{array}{l}7.97 \\
9.30\end{array}$ & $\begin{array}{l}36.36 \\
38.00\end{array}$ & $\begin{array}{l}7.60 \\
7.50\end{array}$ & $\begin{array}{l}1.36 \\
1.55\end{array}$ & $\begin{array}{l}6.39 \\
5.80\end{array}$ & $\begin{array}{l}0.97 \\
0.96\end{array}$ & $\begin{array}{l}4.96 \\
5.20\end{array}$ & $\begin{array}{l}0.95 \\
1.02\end{array}$ & $\begin{array}{l}2.79 \\
3.00\end{array}$ & $\begin{array}{l}0.40 \\
0.43\end{array}$ & $\begin{array}{l}2.60 \\
2.60\end{array}$ & $\begin{array}{l}0.38 \\
0.40\end{array}$ & $\begin{array}{l}3.62 \\
3.70\end{array}$ \\
\hline $\begin{array}{l}\text { BIR-1 } \\
\text { Reference values }\end{array}$ & USGS & $\begin{array}{l}0.74 \\
0.62\end{array}$ & $\begin{array}{l}2.22 \\
1.95\end{array}$ & $\begin{array}{l}0.34 \\
0.38\end{array}$ & $\begin{array}{l}2.45 \\
2.50\end{array}$ & $\begin{array}{l}1.17 \\
1.10\end{array}$ & $\begin{array}{l}0.51 \\
0.54\end{array}$ & $\begin{array}{l}1.88 \\
1.85\end{array}$ & $\begin{array}{l}0.41 \\
0.36\end{array}$ & $\begin{array}{l}2.62 \\
2.50\end{array}$ & $\begin{array}{l}0.58 \\
0.57\end{array}$ & $\begin{array}{l}1.78 \\
1.70\end{array}$ & $\begin{array}{l}0.27 \\
0.26\end{array}$ & $\begin{array}{l}1.76 \\
1.65\end{array}$ & $\begin{array}{l}0.24 \\
0.26\end{array}$ & $\begin{array}{l}0.69 \\
0.60\end{array}$ \\
\hline $\begin{array}{l}\text { DNC-1 } \\
\text { Reference values }\end{array}$ & USFS & $\begin{array}{l}3.89 \\
3.80\end{array}$ & $\begin{array}{r}8.57 \\
10.60\end{array}$ & $\begin{array}{l}0.90 \\
1.30\end{array}$ & $\begin{array}{l}4.99 \\
4.90\end{array}$ & $\begin{array}{l}1.57 \\
1.38\end{array}$ & $\begin{array}{l}0.60 \\
0.59\end{array}$ & $\begin{array}{l}2.14 \\
2.00\end{array}$ & $\begin{array}{l}0.43 \\
0.41\end{array}$ & $\begin{array}{l}2.80 \\
2.70\end{array}$ & $\begin{array}{l}0.63 \\
0.62\end{array}$ & $\begin{array}{l}2.00 \\
2.00\end{array}$ & $\begin{array}{r}0.31 \\
0.33\end{array}$ & $\begin{array}{l}2.05 \\
2.01\end{array}$ & $\begin{array}{l}0.31 \\
0.32\end{array}$ & $\begin{array}{l}1.36 \\
1.01\end{array}$ \\
\hline $\begin{array}{l}\text { W-2 } \\
\text { Reference values }\end{array}$ & USGS & $\begin{array}{l}10.54 \\
11.40\end{array}$ & $\begin{array}{l}23.36 \\
24.00\end{array}$ & $\begin{array}{l}2.42 \\
(5.9\end{array}$ & $\begin{array}{l}13.03 \\
14.00\end{array}$ & $\begin{array}{l}3.37 \\
3.25\end{array}$ & $\begin{array}{l}1.05 \\
1.10\end{array}$ & $\begin{array}{l}3.70 \\
3.60\end{array}$ & $\begin{array}{l}0.66 \\
0.63\end{array}$ & $\begin{array}{l}3.74 \\
3.80\end{array}$ & $\begin{array}{l}0.75 \\
0.76\end{array}$ & $\begin{array}{l}2.25 \\
2.50\end{array}$ & $\begin{array}{l}0.35 \\
0.38\end{array}$ & $\begin{array}{l}2.05 \\
2.05\end{array}$ & $\begin{array}{l}0.30 \\
0.33\end{array}$ & $\begin{array}{l}3.40 \\
2.56\end{array}$ \\
\hline $\begin{array}{l}\text { SY-2 } \\
\text { Reference values }\end{array}$ & CCRMP & $\begin{array}{l}81.31 \\
75.00\end{array}$ & $\begin{array}{l}164.40 \\
175.00\end{array}$ & $\begin{array}{l}17.72 \\
18.80\end{array}$ & $\begin{array}{l}74.54 \\
73.00\end{array}$ & $\begin{array}{l}16.26 \\
16.40\end{array}$ & $\begin{array}{l}2.39 \\
2.42\end{array}$ & $\begin{array}{l}17.09 \\
17.00\end{array}$ & $\begin{array}{l}3.24 \\
2.50\end{array}$ & $\begin{array}{l}18.52 \\
18.00\end{array}$ & $\begin{array}{l}4.38 \\
3.80\end{array}$ & $\begin{array}{l}14.88 \\
12.40\end{array}$ & $\begin{array}{l}2.53 \\
2.10\end{array}$ & $\begin{array}{l}18.70 \\
(17\end{array}$ & $\begin{array}{l}2.97 \\
2.70\end{array}$ & $\begin{array}{l}8.28 \\
7.70\end{array}$ \\
\hline $\begin{array}{l}\text { SY-3 } \\
\text { Reference values }\end{array}$ & CCRMP & $\begin{array}{l}1327.41 \\
1340.00\end{array}$ & $\begin{array}{l}1851.07 \\
2230.00\end{array}$ & $\begin{array}{l}193.41 \\
223.00\end{array}$ & $\begin{array}{l}698.63 \\
670.00\end{array}$ & $\begin{array}{l}126.80 \\
109.00\end{array}$ & $\begin{array}{l}17.42 \\
17.00\end{array}$ & $\begin{array}{l}123.75 \\
105.00\end{array}$ & $\begin{array}{l}22.14 \\
18.00\end{array}$ & $\begin{array}{l}118.38 \\
118.00\end{array}$ & $\begin{array}{l}27.88 \\
29.50\end{array}$ & $\begin{array}{l}75.49 \\
68.00\end{array}$ & $\begin{array}{l}13.08 \\
11.60\end{array}$ & $\begin{array}{l}68.96 \\
(62\end{array}$ & $\begin{array}{l}8.38 \\
7.90\end{array}$ & $\begin{array}{l}7.45 \\
9.70\end{array}$ \\
\hline $\begin{array}{l}\text { GXR-1 } \\
\text { Reference values }\end{array}$ & USGS & $\begin{array}{l}9.15 \\
7.20\end{array}$ & $\begin{array}{l}17.69 \\
17.00\end{array}$ & $\begin{array}{l}1.77 \\
\mathrm{NV}\end{array}$ & $\begin{array}{l}8.99 \\
(18\end{array}$ & $\begin{array}{l}3.08 \\
2.70\end{array}$ & $\begin{array}{l}0.61 \\
0.69\end{array}$ & $\begin{array}{l}4.29 \\
4.20\end{array}$ & $\begin{array}{l}0.82 \\
0.83\end{array}$ & $\begin{array}{l}4.80 \\
4.30\end{array}$ & $\begin{array}{l}0.94 \\
\mathrm{NV}\end{array}$ & $\begin{array}{l}2.79 \\
\mathrm{NV}\end{array}$ & $\begin{array}{r}0.42 \\
(0.43\end{array}$ & $\begin{array}{l}2.26 \\
1.90\end{array}$ & $\begin{array}{l}0.31 \\
0.28\end{array}$ & $\begin{array}{l}0.96 \\
0.96\end{array}$ \\
\hline $\begin{array}{l}\text { MRG-1 } \\
\text { Reference values }\end{array}$ & CCRMP & $\begin{array}{r}10.63 \\
9.80\end{array}$ & $\begin{array}{l}26.75 \\
26.00\end{array}$ & $\begin{array}{l}3.28 \\
3.40\end{array}$ & $\begin{array}{l}17.08 \\
19.20\end{array}$ & $\begin{array}{l}4.62 \\
4.20\end{array}$ & $\begin{array}{l}1.37 \\
1.39\end{array}$ & $\begin{array}{l}4.30 \\
4.00\end{array}$ & $\begin{array}{l}0.59 \\
0.51\end{array}$ & $\begin{array}{l}2.69 \\
2.90\end{array}$ & $\begin{array}{l}0.47 \\
0.49\end{array}$ & $\begin{array}{l}1.08 \\
1.12\end{array}$ & $\begin{array}{l}0.14 \\
0.11\end{array}$ & $\begin{array}{l}0.76 \\
0.6\end{array}$ & $\begin{array}{l}0.11 \\
0.12\end{array}$ & $\begin{array}{l}3.68 \\
3.76\end{array}$ \\
\hline $\begin{array}{l}\text { BHVO-1 } \\
\text { Reference values }\end{array}$ & USGS & $\begin{array}{l}14.65 \\
15.80\end{array}$ & $\begin{array}{l}37.74 \\
39.00\end{array}$ & $\begin{array}{l}4.14 \\
5.70\end{array}$ & $\begin{array}{l}22.17 \\
25.20\end{array}$ & $\begin{array}{l}5.99 \\
6.20\end{array}$ & $\begin{array}{l}1.92 \\
2.06\end{array}$ & $\begin{array}{l}6.02 \\
6.40\end{array}$ & $\begin{array}{l}0.98 \\
0.96\end{array}$ & $\begin{array}{l}5.09 \\
5.20\end{array}$ & $\begin{array}{l}0.93 \\
0.99\end{array}$ & $\begin{array}{l}2.45 \\
2.40\end{array}$ & $\begin{array}{l}0.30 \\
0.33\end{array}$ & $\begin{array}{l}1.88 \\
2.02\end{array}$ & $\begin{array}{l}0.26 \\
0.29\end{array}$ & $\begin{array}{l}5.52 \\
4.38\end{array}$ \\
\hline $\begin{array}{l}\text { FER-3 } \\
\text { Reference values }\end{array}$ & CCRMP & $\begin{array}{l}1.71 \\
2.00\end{array}$ & $\begin{array}{l}2.29 \\
2.00\end{array}$ & $\begin{array}{c}0.22 \\
\mathrm{NV}\end{array}$ & $\begin{array}{l}1.40 \\
\mathrm{NV}\end{array}$ & $\begin{array}{l}0.54 \\
0.58\end{array}$ & $\begin{array}{l}0.22 \\
0.24\end{array}$ & $\begin{array}{l}0.33 \\
0.30\end{array}$ & $\begin{array}{c}0.05 \\
\mathrm{NV}\end{array}$ & $\begin{array}{l}0.35 \\
0.30\end{array}$ & $\begin{array}{l}0.08 \\
0.10\end{array}$ & $\begin{array}{l}0.26 \\
\mathrm{NV}\end{array}$ & $\begin{array}{l}0.04 \\
\mathrm{NV}\end{array}$ & $\begin{array}{l}0.27 \\
0.20\end{array}$ & $\begin{array}{l}0.04 \\
0.04\end{array}$ & $\begin{array}{c}<0.05 \\
\mathrm{NV}\end{array}$ \\
\hline
\end{tabular}

Notes: CCRMP = Canadian Certified Reference Materials Project; USGS = U.S. Geological Survey. Underline = recommended values; other values are proposed except for those preceded by a "(", which are information values. NV = no value.

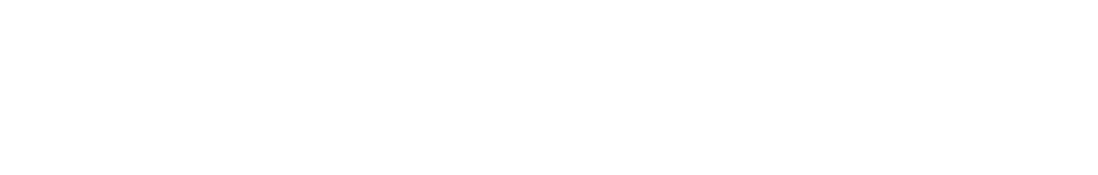

